INTER NATIONAL MONETARY FUND
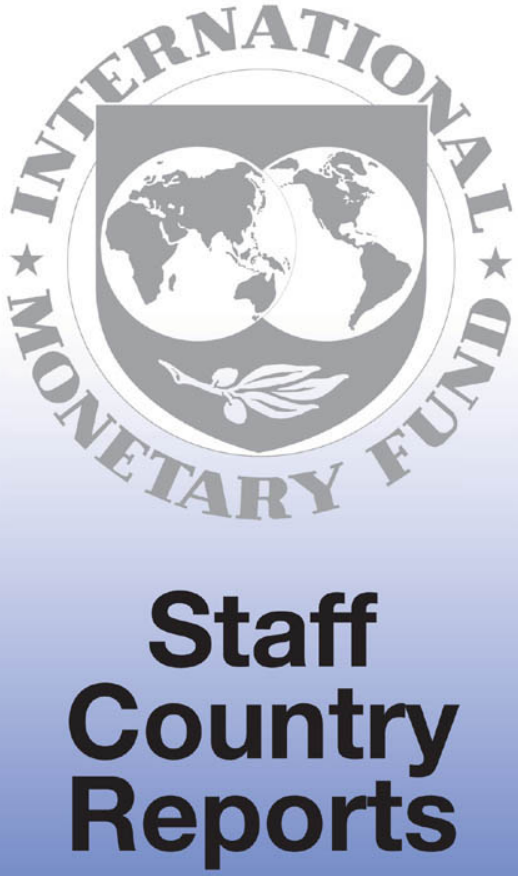


\section{Honduras: Third Review Under the Three-Year Arrangement Under the Poverty Reduction and Growth Facility; Request for Waiver and Modification of Performance Criteria; and Financing Assurances Review-Staff Report; Staff Statement; Press Release on the Executive Board Discussion; and Statement by the Executive Director for Honduras}

In the context of third review under the three-year arrangement under the Poverty Reduction and Growth Facility; request for a waiver and modification of performance criteria; and financing assurances review, the following documents have been released and are included in this package:

- $\quad$ the staff report for the Third Review Under the Three-Year Arrangement Under the Poverty Reduction and Growth Facility; Request for Waiver and Modification of Performance Criteria; and Financing Assurances Review, prepared by a staff team of the IMF, following discussions that ended on October 8, 2005, with the officials of Honduras on economic developments and policies. Based on information available at the time of these discussions, the staff report was completed on November 23, 2005. The views expressed in the staff report are those of the staff team and do not necessarily reflect the views of the Executive Board of the IMF.

- $\quad$ a staff statement of December 16, 2005 updating information on recent economic developments.

- $\quad$ a Press Release, summarizing the views of the Executive Board as expressed during its December 16, 2005 discussion of the staff report that completed the review and request.

- $\quad$ a statement by the Executive Director of Honduras.

The documents listed below have been or will be separately released.

Letter of Intent sent to the IMF by the authorities of Honduras* Supplementary Memorandum of Economics Policies* Supplementary Technical Memorandum of Understanding* *May also be included in Staff Report

The policy of publication of staff reports and other documents allows for the deletion of market-sensitive information.

To assist the IMF in evaluating the publication policy, reader comments are invited and may be sent by e-mail to publicationpolicy@imf.org.

Copies of this report are available to the public from

International Monetary Fund • Publication Services

$70019^{\text {th }}$ Street, N.W. • Washington, D.C. 20431

Telephone: (202) 623-7430 • Telefax: (202) 623-7201

E-mail: publications@imf.org • Internet: http://www.imf.org

Price: $\$ 15.00$ a copy

\section{International Monetary Fund Washington, D.C.}


This page intentionally left blank 
INTERNATIONAL MONETARY FUND

HONDURAS

\title{
Third Review Under the Three-Year Arrangement Under the Poverty Reduction and Growth Facility; Request for Waiver and Modification of Performance Criteria; and Financing Assurances Review
}

\author{
Prepared by Western Hemisphere Department
}

Approved by Caroline Atkinson and Adnan Mazarei

November 23, 2005

Third review. The authorities consider that the completion of the review would provide a policy framework through the political transition and beyond. Program implementation has been broadly satisfactory, although the performance criterion (PC) against unfinanced appropriations was not observed as the result of a congressionally imposed fuel price freeze. The staff supports the request for a waiver based on otherwise strong performance in a difficult external and domestic environment. All end-June 2005 PCs were met, with wide margins on NIR and deficit targets, and the structural agenda has moved forward. Inflation has stabilized, albeit at a higher level than expected.

Key policy issues. Key policy issues for the review were spending pressures prior to the elections in November 2005; the 2006 budget, including the impact of CAFTA and telecom reform; reform of monetary policy and operations; enhancing financial sector regulation and supervision including on banks' dollar operations; and the response to the recent fuel price shocks including the fiscal impact of the fuel price freeze.

Discussions. Discussions for the third review under the PRGF arrangement were held in Tegucigalpa during August 22-September 3, September 15-17, and October 4-8, 2005 and in Washington D.C. during the Annual Meetings. The mission met with President Maduro, senior government officials, leaders of congress, and representatives of the private sector and civil society. The team comprised L. Breuer (Head), F. Balcells, J.C. Jaramillo, C. Macario (all WHD), J. Cayazzo (MFD), and A. Segura (FAD), and was assisted by H. Monroe, the resident representative. Ms. Conrado (OED) participated in some policy discussions.

Fund relations. A three-year PRGF arrangement was approved on February 27, 2004 for SDR 71.2 million (55 percent of quota), of which SDR 30.51 million has been disbursed. On March 28, 2005, the Article IV consultation was concluded and the second program review was completed, and Honduras reached completion point under the enhanced HIPC initiative on April 6, 2005. Honduras has accepted the obligations under Article VIII, Section 2, 3, and 4 of the Articles of Agreement, and maintains an exchange system that is free of restrictions on the making of payments and transfers for current transactions. 


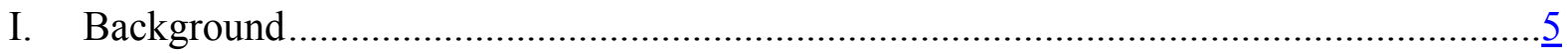

II. Policy Discussions ........................................................................................... 11

A. Macroeconomic Framework ......................................................................

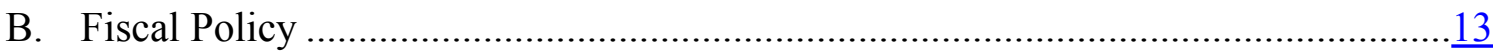

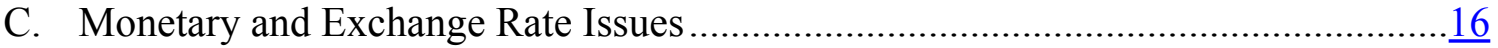

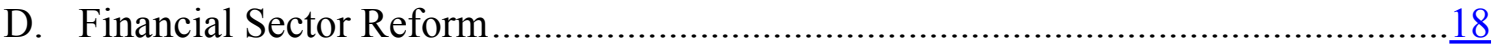

E. Financing Assurances .................................................................................... $\frac{19}{20}$

F. Program Modalities ....................................................................................

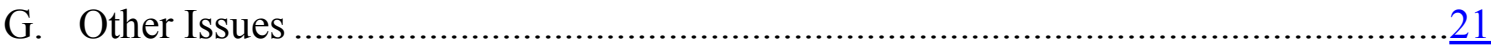

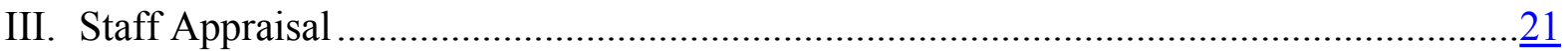

Boxes

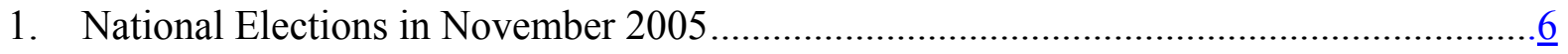

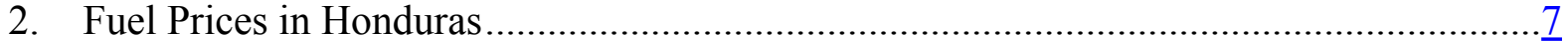

3. Managing Liquidity from High Foreign Exchange Inflows ......................................17

Figures

1. Real and External Sector Developments .......................................................... $\underline{9}$

2. Fiscal and Monetary Sector Developments ..........................................................

Tables

1. Selected Economic Indicators.............................................................................24

2. Operations of the Central Government (In Percent of GDP) ....................................25

3. Operations of the Central Government - Quarterly (Cumulative) .................................26

4. Operations of the Combined Public Sector (In percent of GDP) ..................................27

5. Operations of the Combined Public Sector - Quarterly (Cumulative) .............................

6. Summary Accounts of the Banking System ...............................................................29

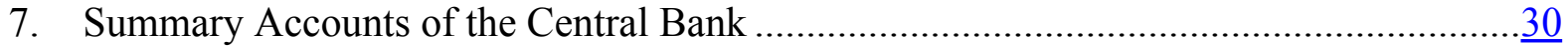

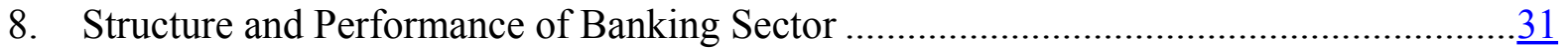

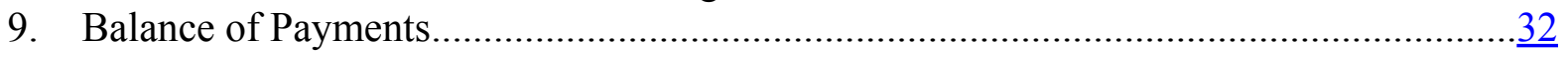

10. Summary of Macroframework ............................................................................33

11. External Financing Requirements and Sources .................................................

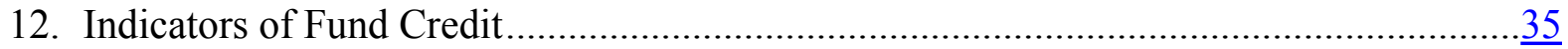

13. Review and Phasing of Disbursements under the PRGF Arrangement ......................... $\underline{36}$ 


\section{Appendices}

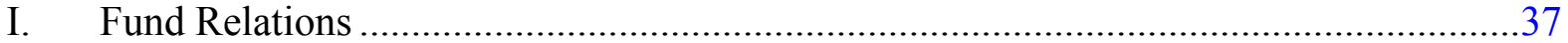

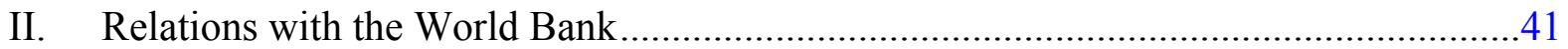

III. Relations with the Inter-American Development Bank .................................................45

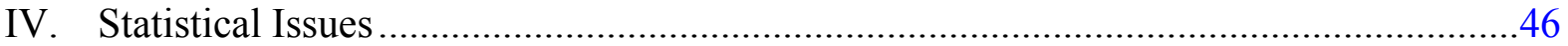

Attachments

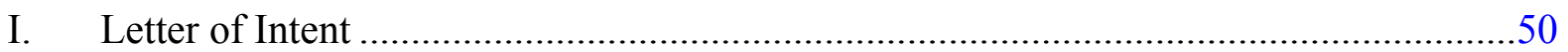

II. Supplementary Memorandum of Economic Policies .................................................52

III. Supplementary Technical Memorandum of Understanding ..........................................61

Attachment Tables

1. Financial Benchmarks and Performance Criteria for 2004-05 under the PRGF.............58

2. Structural Targets for 2004-05 under the PRGF Arrangement ......................................59 


\section{EXECUTIVE SUMMARY}

Political tensions are high prior to general elections on November 27, 2005, exacerbated by high fuel prices. The sharp increase in domestic fuel prices following Hurricane Katrina triggered a wave of social unrest, which was followed by a congressionally imposed freeze in fuel prices at pre-Katrina levels which has since been effectively lifted (except for LPG). Performance under the program has otherwise been satisfactory, with overperformance on fiscal and NIR targets through the first half of 2005. Real GDP is expected to grow by more than 4 percent in 2005; inflation has stabilized; and the external sector has continued to strengthen. The financial sector has also continued its recovery, although it remains fragile.

The key policy challenge will be to maintain fiscal discipline through the political transition and beyond. This will be demanding, against the background of high political and social tensions prior to the elections. Additional challenges will be faced in 2006, including the integration of teachers' benefits into the overall salary structure and the need for measures to offset the fiscal impact of the opening of the telecommunications market and the implementation of CAFTA.

The macroeconomic framework has been revised to reflect somewhat higher inflation on account of higher fuel prices. The private sector has favorable growth expectations as a result of CAFTA, although there are concerns over high oil prices. The external sector is expected to remain strong on account of rapid growth of family remittances.

The current stance of monetary and exchange rate policies are broadly appropriate, and financial sector reforms are proceeding. Progress has been made in strengthening monetary operations and the prudential framework. The authorities will introduce measures to control the risk of dollar lending to non-dollar earners and to limit the net open foreign exchange position of banks. These measures will allow for the gradual reform of banks' liquidity requirements in foreign currency, to level the playing field with banks from other countries in the region that face much lower requirements.

Risks to the program remain high. The main near-term risks are associated with the influence of vested interests during the electoral process, in the context of high fuel prices. In this environment, congress could revisit earlier initiatives inconsistent with the program. Dissatisfaction produced by high fuel prices could weaken public support for the program. 


\section{BACKGROUND}

1. Political tensions are high in the run-up to the general elections on November 27, 2005, exacerbated by high fuel prices. Presidential, legislative, and municipal elections will take place at the same time (Box 1). In early September, increases in domestic fuel pricesreflecting the full pass through of higher international prices in the aftermath of Hurricane Katrina-triggered social unrest and street blockages in all major cities (Box 2). ${ }^{1}$ In reaction, on September 7, congress rolled back the increase in fuel prices; froze fuel prices and charged the cost to the budget; ${ }^{2}$ named a special commission (Commission) to design a new domestic fuel price mechanism; ${ }^{3}$ raised subsidies to electricity consumers; and established price controls over basic foodstuffs. In addition, during the past few months, the authorities successfully addressed a prolonged strike of public workers and student demonstrations, while the influential public teachers have been on strike intermittently.

2. Recent macroeconomic developments have been broadly positive. In 2005, real GDP is expected to grow by more than 4 percent. This is somewhat lower than last year, reflecting lower agricultural output, lower private investment, and higher oil prices, ${ }^{4}$ but growth is expected to accelerate again in 2006, due partly to the impact of CAFTA on investment and confidence. ${ }^{5}$

\footnotetext{
${ }^{1}$ Gasoline prices rose by about 25 percent and diesel prices by about 9 percent.

${ }^{2}$ A flexible mechanism for setting fuel prices (except liquid propane gas) was reintroduced starting on October 18 as international fuel prices fell below pre-Katrina levels.

${ }^{3}$ The commission is chaired by Cardinal Rodriguez and consists of representatives from the private sector and civil society. It is entrusted with recommending improvements to the domestic fuel price adjustment mechanism.

${ }^{4}$ Despite higher oil prices, the authorities believe that the growth objective for 2005 4.2 percent - will be met, on account of stronger-than-expected growth in the first semester ( 5 percent with respect to the same period in 2004 , as reflected in partial data from monthly indicators of economic activity).
}

${ }^{5}$ A recent staff study suggests that the impact of CAFTA on growth in Honduras could be sizable, with a first-round static impact on GDP of 4.7 percent (Kose et al, "Macroeconomic Implications of CAFTA-DR," in Central America: Global Integration and Regional Cooperation, Occasional Paper 243). However, program projections are more cautious. 


\section{Box 1. National Elections in November 2005}

Presidential, congressional, and municipal elections will take place on November 27, 2005 and the new administration will take office on January 27, 2006. The two main presidential candidates are Mr. Porfirio Lobo of the governing National Party and Mr. Manuel Zelaya of the opposition Liberal Party. The main parties do not differ much ideologically, and, through consensus building, Honduras has avoided the polarization and violence that engulfed the region in the $1980 \mathrm{~s}$.

Mr. Lobo has focused his campaign on law and order issues. As president of congress (2002-present), he has supported the government's economic program and played a key role in obtaining legislative approval of its core elements.

Mr. Zelaya has focused his messages on jobs and the rising cost of living. In an earlier Liberal administration, he ran the government's social investment fund.

The impact of the electoral process on Honduras' economic program could be significant. Although programs have traditionally gone off track in Honduras during elections, the current administration has so far succeeded in protecting its core elements. Although a number of proposals by the candidates may largely reflect pre-election attempts to win popularity (including reducing taxes and increasing public wages), some could complicate their ability in government to maintain a prudent economic program.

\section{Inflation has stabilized, albeit at a higher level than expected. After drifting} upward during much of 2004, reflecting mainly the surge in oil prices (passed through to domestic petroleum prices) and the monetary impact of foreign exchange inflows, inflation has hovered around 9 percent since Q3 2004. By end 2005, inflation is projected to be about 8.0-9.0 percent, somewhat above the target (6.9 percent), due largely to oil price increases.

\section{The external sector has continued to strengthen, boosted by remittances and} exports. In the first half of 2005 , NIR rose by slightly over 2 percent of GDP (US\$171 million), owing mainly to remittances that jumped by about 50 percent, compared to the same period of the previous year - an increase equivalent to 5 percent of GDP at an annual rate. ${ }^{6}$ Exports expanded by some 17 percent over the same period.

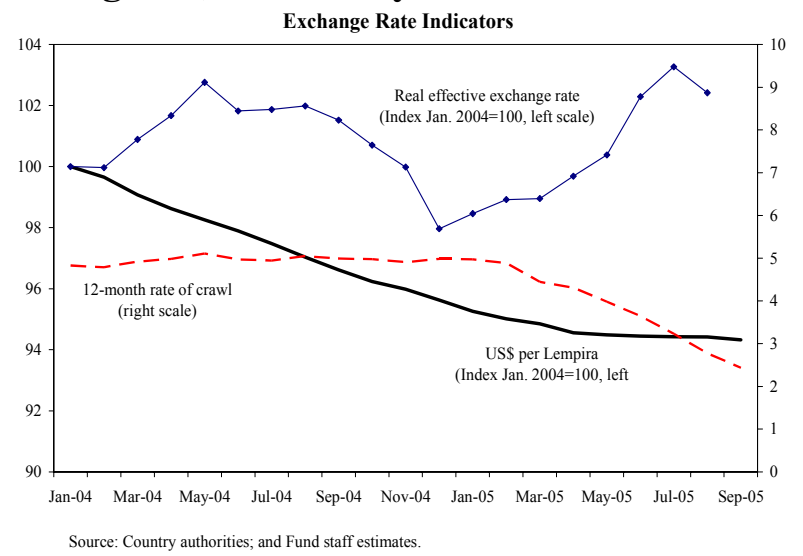

${ }^{6}$ NIR increased by US\$197 million in 2005 through end-July. 


\section{Box 2. Fuel Prices in Honduras}

Although Honduras is very vulnerable to international oil price movements, the country has generally adjusted well to increases in oil prices. In response to the spike in international gasoline prices after Hurricane Katrina, congress mandated a fuel price freeze. However, with international prices falling below pre-Katrina levels, the government has recently reintroduced a flexible price adjustment mechanism for most fuels (excluding $L P G$ ).

Honduras had until recently adjusted well to higher international oil prices. The country imports all of its fuel and about 80 percent of electricity generation is based on petroleum. However, the rapid growth of family remittances has more than offset the balance of payments impact of the higher oil bill; ${ }^{1}$ inflation has remained steady since late 2004, as noted; and growth has been resilient, with output still benefiting from the strong recovery in 2004 and improved confidence. ${ }^{2}$

Honduras: Internal and External Gasoline Prices, 2002-2005 (In U.S. Dollars)

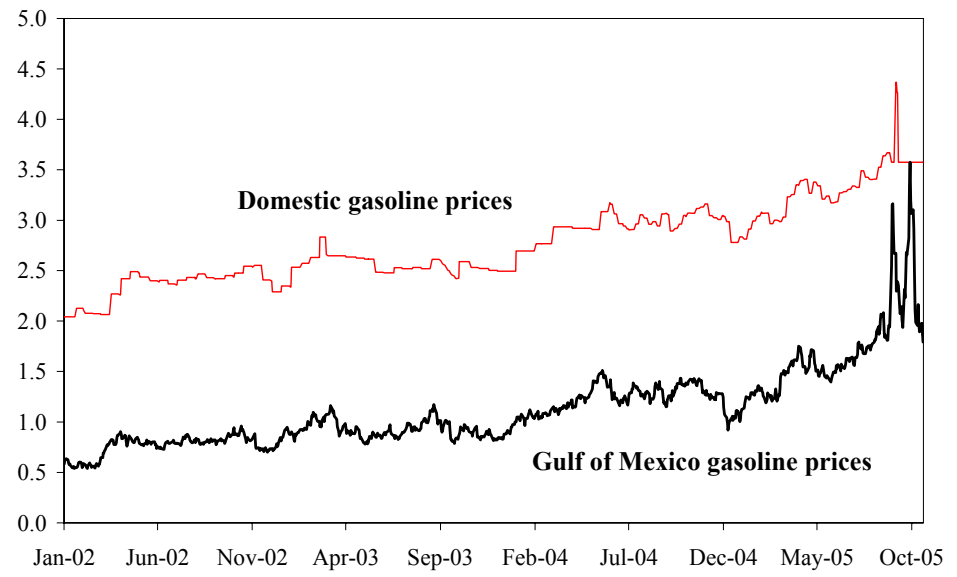

Institutional arrangements have generally allowed international price changes to be passed through to domestic prices and are key in allowing adjustment to higher oil prices and in protecting public finances. In particular, domestic fuel prices have been adjusted weekly based on a formula that includes the average price of U.S. Gulf fuel products of the previous week, taxes, and margins for distributors and retailers. In addition, electricity rates include a fuel component that has varied (albeit only partially) with international fuel prices. Revenues from fuel taxes (which account for about 20 percent of total expenditures) have remained relatively unaffected from the higher prices.

Recent developments put a temporary hold on these pass-through mechanisms. Following Hurricane Katrina, on September 2 domestic gasoline prices were raised by 25 percent and diesel by 9 percent, reflecting higher imported fuel prices. Ensuing transportation strikes and public discontent led congress on September 7 to roll back fuel prices and freeze fuel prices for a period of 10 days (which was subsequently extended by the authorities). On October 18, congress authorized fuel subsidies for up to 0.2 percent of GDP in 2005. Following the decline in international prices to pre-Katrina levels, the government subsequently reintroduced a flexible price setting mechanism for fuel products except LPG, which accounts for less than 5 percent of fuel consumption (at a negligible cost for the budget for the remainder of the year).

${ }^{1}$ The oil import bill has gone from 5.8 percent of GDP in 2002 to a projected 12.5 percent of GDP in 2005, while remittances rose from 11 percent of GDP to over 20 percent of GDP during the same period.

${ }^{2}$ The effects on growth will of course depend on the permanence of the oil price shock. If oil prices remain at their 2005 average, rather than declining in line with futures prices, Honduras' growth rate would fall by about 0.4 percent this year, and by about $0.1-0.2$ percent over the longer term. 


\section{With one exception, program implementation has been satisfactory.}

- $\quad$ All performance criteria (PC) for end-June were met, some with wide margins. ${ }^{7}$ NIR exceeded the program floor by over 1 percent of GDP. The overall public sector had a surplus in the first half of about 0.4 percent of GDP (compared with a program deficit ceiling of 1.1 percent of GDP). Progress has also been made on the structural agenda, including on the reform of monetary operations (launching of the corridor for central bank interest rates) and tax administration (reducing stop-filers and increasing audits).

- However, a continuous performance criterion on unfinanced appropriations was not observed when congress imposed the cost of the 10-day fuel price freeze on the budget.

6. The fiscal program is broadly on track. In the first half of 2005, central government revenues were broadly in line with the program projection (with buoyant tax revenues compensating for delays in grant disbursements), while spending was lower (by about 0.6 percent of GDP) due to strict control over the wage bill ( 0.2 percent of GDP), lower capital expenditures ( 0.2 percent of GDP), and a reduction in net lending $(0.2$ percent of GDP). ${ }^{8}$ In the consolidated public sector, investment by the public enterprises was markedly lower than expected through June 2005 (by over 1 percent of GDP), owing mainly to delays in the bidding and awarding of projects related to investments by the public telephone company (Hondutel) and public electricity company (ENEE). In the case of ENEE, the deterioration in the company's financial conditions (described below) impaired its ability to finance investment projects.

7. The financial sector continues its recovery. Bank profitability has improved further since end-2004 while other indicators on capital adequacy, nonperforming loans, and provisions to NPLs have improved slightly. ${ }^{9}$

\footnotetext{
${ }^{7}$ Indicative targets on NIR and NDA for end-September 2005 were also met.

${ }^{8}$ The wage bill for the full year is expected to be in line with the program projection, as the overperformance in the first half will be offset in the second half by expected wage adjustments (in line with the program), the hiring of new teachers, health workers and police, and severance payments.

${ }^{9}$ The CNBS is enforcing the timetable for improving provisioning for nonperforming loans, based on the recently introduced norms for loan classification and provisioning.
} 
Figure 1. Honduras: Real and External Sector Developments
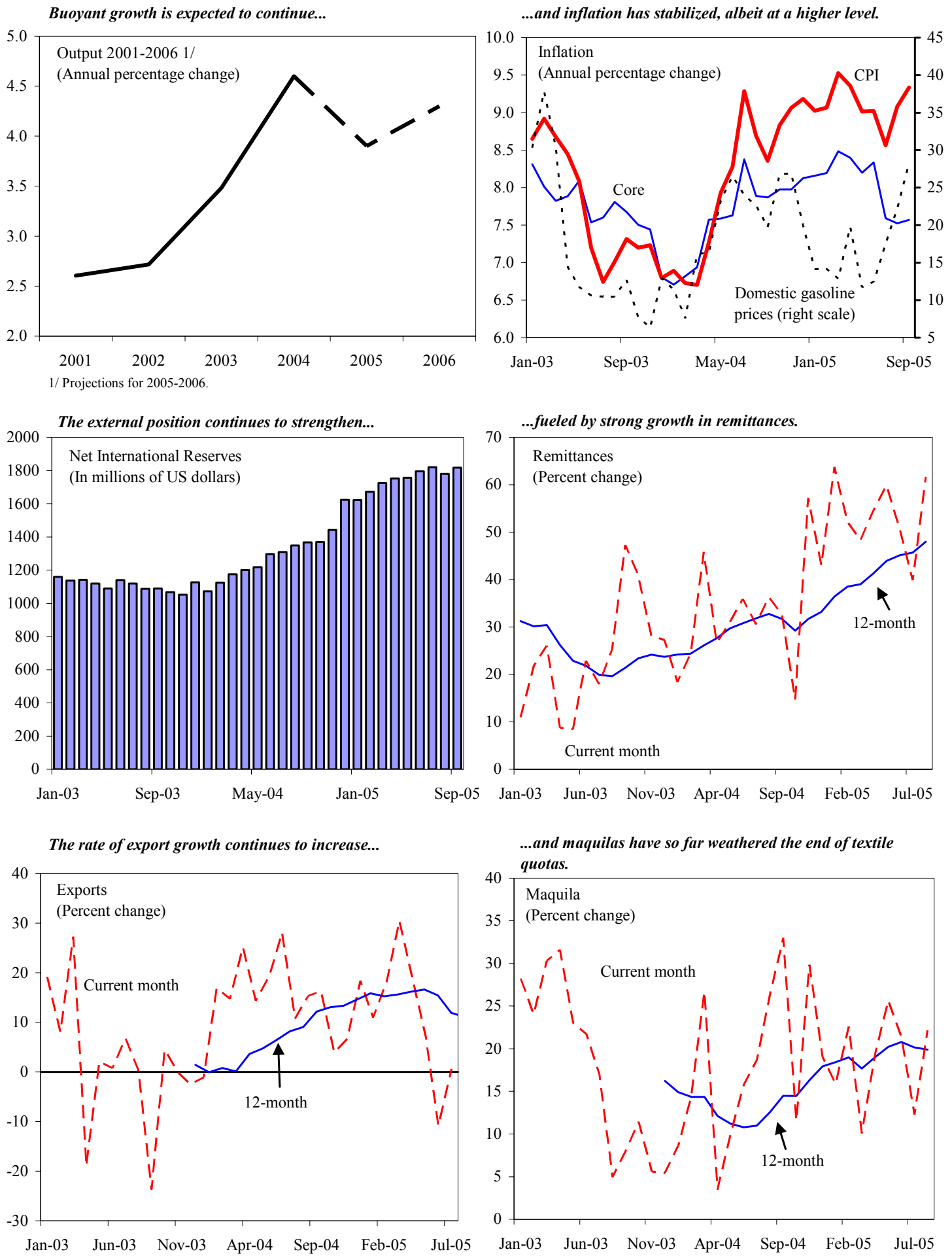

Source: Country authorities; and Fund staff estimates. 
Figure 2. Honduras: Fiscal and Monetary Sector Developments
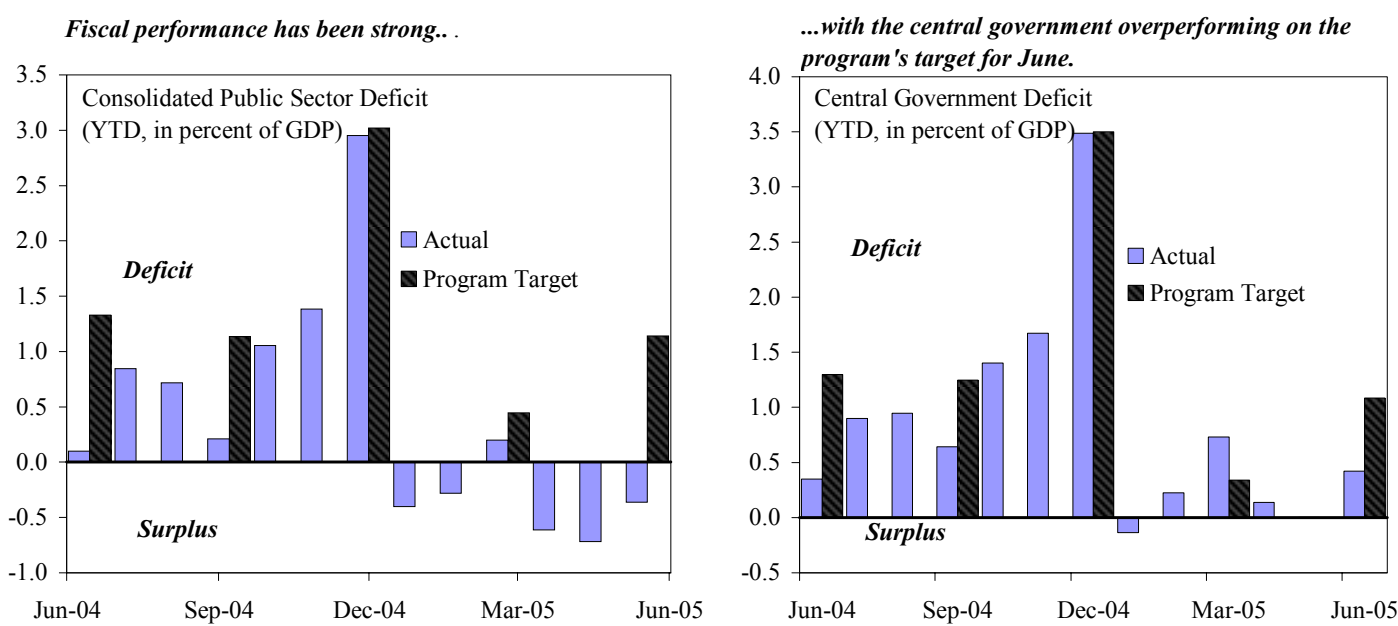

Tax revenues have continued to grow...

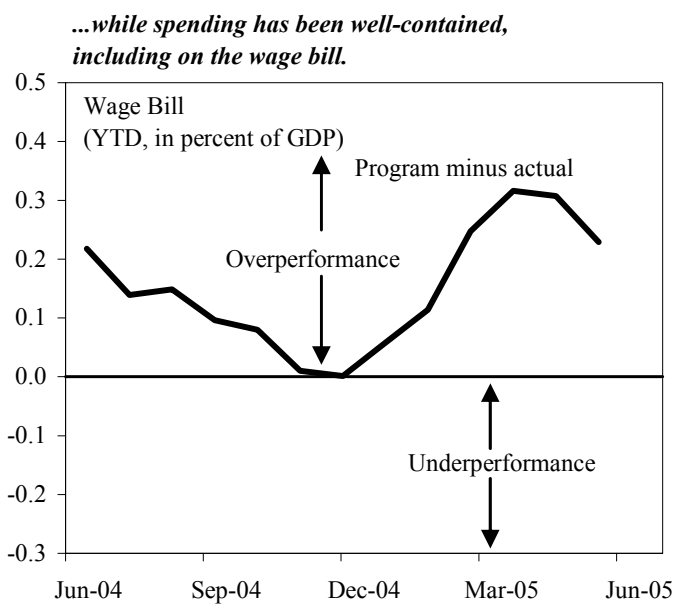

Growth of monetary aggregates had slowed down somewhat, but rebounded in September...
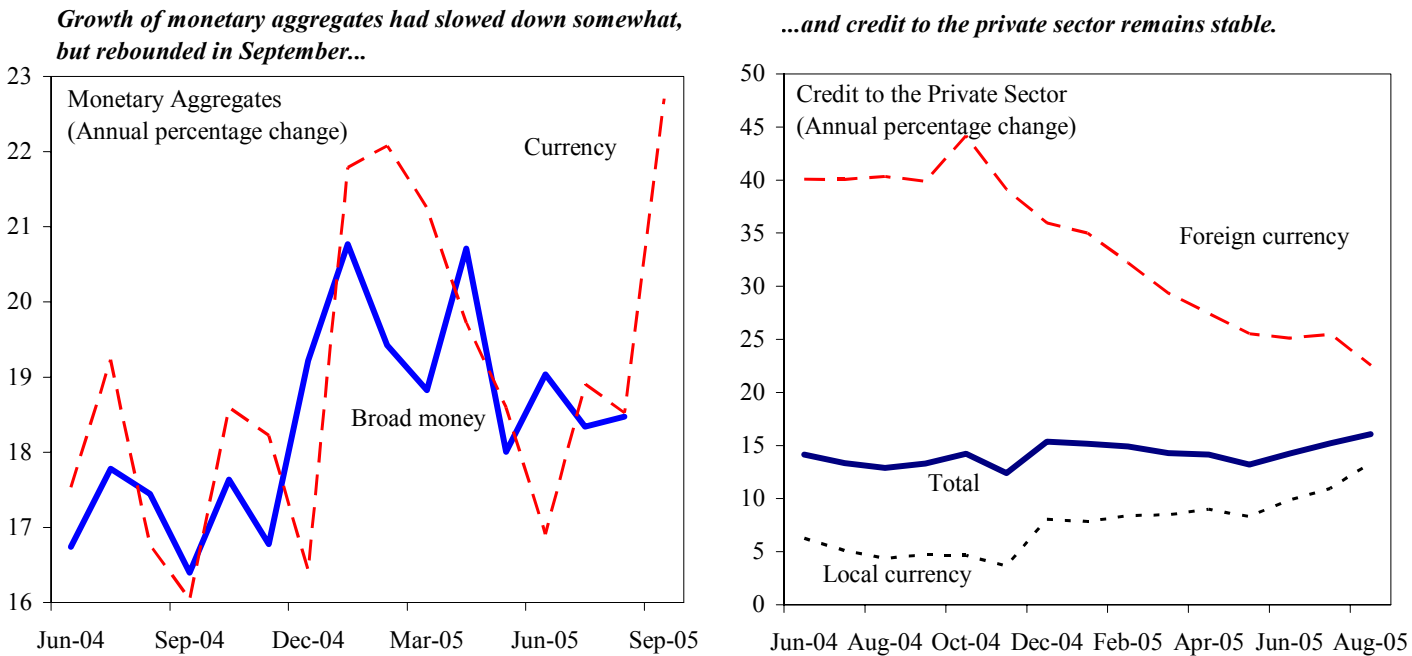

Source: Country authorities; and Fund staff estimates. 


\begin{tabular}{|lrrrrr}
\hline \multicolumn{2}{c}{ Honduras: Banking Sector Indicators } & & & \\
\hline & & & & Prel. \\
& & & & June \\
& 2001 & 2002 & 2003 & 2004 & 2005 \\
\hline Regulatory capital to risk-weighted assets & 12.7 & 12.9 & 13.0 & 14.5 & 14.8 \\
Nonperforming loans (NPLs) to total loans & 11.4 & 11.3 & 8.7 & 6.4 & 6.2 \\
Provisions to NPLs & 27.2 & 38.7 & 38.2 & 64.6 & 66.6 \\
Return on assets (ROA) & 0.9 & 0.8 & 1.2 & 1.2 & 1.5 \\
Return on equity (ROE) & 8.4 & 8.2 & 11.8 & 14.9 & 17.6 \\
\hline
\end{tabular}

Sources: Comision Nacional de Bancos y Seguros; and Fund staff estimates.

8. The impact of Hurricanes Katrina and Rita on Honduras was significant. In addition to the surge in imported fuel prices, the displacement by Hurricane Katrina of an estimated 100,000 Honduran immigrants in the United States is expected to dampen slightly the rapid growth in family remittances. There has also been a limited and temporary impact on exports, particularly of bananas and coffee, since the Gulf ports were, until recently, the main entry points for Honduran exports to the United States.

\section{Policy Discussions}

9. The key challenge will be to maintain macroeconomic stability based on fiscal discipline during the political transition and beyond, against the background of political and social tensions in the run-up to the elections and significant fiscal challenges in 2006. The latter include the need to offset the impact on government revenues of telecom reform and CAFTA and to integrate teachers' benefits into overall salaries.

\section{A. Macroeconomic Framework}

10. The macroeconomic framework for $\mathbf{2 0 0 5}$ has been revised to reflect somewhat higher inflation on account of higher fuel prices. Proposed program targets for 2005-06 are in line with the medium-term framework under the PRGF. Discussions with the private sector indicated favorable growth expectations as a result of CAFTA, although there are concerns over high oil prices and the political transition. The external sector is expected to remain strong on account of rapid growth of family remittances, which, as noted, have more than offset the higher fuel import bill. 


\begin{tabular}{|c|c|c|c|c|}
\hline \multicolumn{5}{|c|}{ Honduras: Macroeconomic Framework (2004-2006) } \\
\hline & \multirow{2}{*}{$\begin{array}{l}\text { Prel. } \\
2004\end{array}$} & \multicolumn{2}{|c|}{2005} & \multirow{2}{*}{$\begin{array}{l}\text { Proj. } \\
2006\end{array}$} \\
\hline & & Program & $\overline{\text { Revised }}$ & \\
\hline \multicolumn{5}{|c|}{ (Annual percentage change) } \\
\hline Real GDP growth & 4.6 & 4.2 & 4.2 & 4.3 \\
\hline Consumer prices, end of period & 9.2 & 6.9 & $8.0-9.0$ & $6.0-7.0$ \\
\hline \multicolumn{5}{|c|}{ (In percent of GDP, unless otherwise stated) } \\
\hline Combined public sector savings & 3.3 & 4.4 & 4.0 & 4.5 \\
\hline Anti-poverty spending & 8.4 & 8.7 & 8.7 & 9.4 \\
\hline Combined public sector balance & -3.0 & -2.5 & -2.5 & -1.7 \\
\hline Of which: central government balance & -3.5 & -3.0 & -3.2 & -2.5 \\
\hline External current account balance & & & & \\
\hline (including official transfers) & -4.7 & -2.5 & -2.1 & -2.9 \\
\hline Gross international reserves (in months of imports) & 4.5 & 4.9 & 4.6 & 4.8 \\
\hline
\end{tabular}

\section{Although there is a wide recognition in Honduras that the program has} delivered positive results, risks to program implementation remain high. The main nearterm risks are political, associated with the influence of vested groups during the electoral process, exacerbated by high fuel prices. ${ }^{10}$ In this environment, congress could revisit earlier proposals such as income tax relief or raise the minimum wage again, while the government's ability to protect the core elements of the program could continue to weaken as the elections approach. Public support for the program may have weakened somewhat, owing to the general dissatisfaction produced by high fuel prices. Fiscal risks for next year are also high, owing to the need to integrate teachers' benefits into the overall salary structure and to address the revenue losses of CAFTA and telecom reform. Moreover, the economy remains vulnerable with a financial sector that is highly susceptible to a shift in economic conditions. On the upside, there is wide recognition in Honduras that the program has produced favorable results. In addition, the Multilateral Debt Relief Initiative has galvanized a forward-looking national debate on how to use debt relief effectively to reduce poverty. Finally, the authorities have committed to taking any necessary offsetting measures to keep their program on track.

\footnotetext{
${ }^{10}$ In Honduras, economic programs went off track prior to the last two elections. In 1997, the program went off track when income taxes were lowered and public sector wages increased (including due to large benefits granted to teachers); and before the 2001 elections, due to similar fiscal imbalances (wage pressures and weak tax collections).
} 


\section{B. Fiscal Policy}

12. While maintaining the core fiscal objectives for $\mathbf{2 0 0 5}$, the authorities are adapting their program to cushion the impact of high oil prices on vulnerable sectors:

- In May, the government announced a subsidy to low-income groups (electricity users consuming less than $100 \mathrm{kwh}$ a month) through year-end, and increased health expenditures (including medicines for public hospitals and expanded health services in poor neighborhoods). They believe the cost (totaling about 0.2 percent of GDP) can be accommodated in the program by using fiscal space for contingencies, including for public investment.

- In September, congress broadened the subsidy to electricity users consuming up to $300 \mathrm{kwh}$ per month (at an additional cost of 0.1 percent of GDP for the remainder of the year) ${ }^{11}$ and mandated spending cuts to offset the fiscal cost. The authorities have taken offsetting expenditure cuts, including a 25 percent cut in spending on goods and services for the rest of the year (excluding defense, health, and education).

- The authorities are proposing an adjustor to the end-December 2005 deficit targets, for up to 0.25 percent of GDP, to allow for faster execution of poverty programs (in line with the poverty reduction strategy) financed with additional concessional external resources.

13. The cost of the fuel subsidies and expanded social safety programs will be accommodated within the overall fiscal framework for 2005, although the central government deficit target for 2005 will be slightly revised. The return to a flexible pricing mechanism, reflecting international prices, for the bulk of domestic fuel consumption will limit the cost of the remaining fuel subsidies (to LPG) to a negligible amount in 2005. The authorities are committed to continue to adjust prices automatically in line with the formula, with the remaining subsidy on LPG contained well within program limits (see Box 2). Once the commission issues its recommendations, the government is expected to return to the fuel pricing issue. Adjusting the mechanism to use a longer moving average (from the current 5day average to say 30 days) to calculate passthrough could provide useful smoothing and reduce the likelihood of spikes in prices in the future. The overall deficit target for 2005 will remain unchanged owing to a lower quasi-fiscal deficit (on account of better returns on NIR investments reflecting higher international interest rates) and some delays in project investments by the public telephone and electricity companies. The central government deficit for end-December will be revised slightly, to 3.2 percent of GDP (from 3.0 percent in the program).

${ }^{11}$ This change expands the coverage from 40 percent to 80 percent of residential users. 


\begin{tabular}{|c|c|c|c|c|}
\hline \multicolumn{5}{|c|}{$\begin{array}{l}\text { Regional Gasoline Prices in Central America } \\
\text { (In U.S. dollars per gallon) }\end{array}$} \\
\hline & \multicolumn{2}{|c|}{ Before Katrina 1/ } & \multicolumn{2}{|c|}{ Latest prices 2/ } \\
\hline & Regular & $\overline{\text { Diesel }}$ & Regular & Diesel \\
\hline Honduras & 3.34 & 2.78 & 3.53 & 2.94 \\
\hline El Salvador & 2.84 & 2.51 & 3.61 & 3.08 \\
\hline Nicaragua & 3.05 & 2.76 & 3.54 & 3.49 \\
\hline Costa Rica & 2.99 & 2.25 & 3.46 & 2.47 \\
\hline Guatemala & 2.82 & 2.27 & 3.5 & 2.66 \\
\hline Average & 3.01 & 2.51 & 3.53 & 2.93 \\
\hline \multicolumn{5}{|c|}{ Source: Official sources, and desks. } \\
\hline \multicolumn{5}{|c|}{$\begin{array}{l}\text { 1/ Prices as of August } 7 \text { (Honduras), August } 10 \text { (El Salvador), August } 8 \\
\text { (Nicaragua), and August } 1 \text { (Costa Rica and Guatemala). } \\
\text { 2/ Prices as of October } 13 \text {. }\end{array}$} \\
\hline
\end{tabular}

14. The authorities will need additional measures to address the weakening finances of the public electricity company (ENEE). In 2005, ENEE is expected to have a loss of about 0.3 percent of GDP on account of rising fuel costs, mounting energy losses owing to theft and transmission losses, and a tariff structure that has only partially kept pace with rising costs. The authorities raised electricity rates in June and September 2005, but further measures will be needed. ${ }^{12}$ Congress has authorized a bond to refinance ENEE's debt to local banks and electricity generators, which is expected to generate some savings on interest costs. The Commission, chaired by Cardinal Rodriguez, recently issued recommendations to improve the financial situation of the company, including an increase in electricity rates, its partial restructuring, changes to existing contracts with private generators, and direct import of fuel from Venezuela. The authorities are reviewing these recommendations.

\section{The draft 2006 budget submitted to congress in mid-September is in line with} the program (prior action). The budget is consistent with a central government deficit of 2.5 percent of GDP, and the wage policy is based on the salaries law passed in December 2003 and the July 2004 wage agreement with teachers. The budget also reflects lower revenue during 2006 due to CAFTA ( 0.25 percent of GDP). ${ }^{13}$ Passage by congress of a budget consistent with the program will be a prior action for the fourth review (expected in April 2006).

12 The basic electricity tariff has been unchanged since 2000 , but the fuel surcharge was raised from 39.9 percent of the basic tariff to 44.9 percent in June 2005 and to 49 percent in September 2005.

${ }^{13}$ CAFTA will enter into force when the United States and Honduras notify their respective ratification of the treaty, and is expected to take effect in January 2006. 
16. The authorities have identified offsetting measures to address the fiscal implications in 2006 of telecom reform (prior action). In January 2006, Hondutel will face competition in long distance and international calls, which will have an estimated fiscal impact of about 0.5 percent of GDP. ${ }^{14}$ The offsetting measures include:

- Increase in the minimum charge on domestic service to regional standards, with a yield of 0.2 percent of GDP.

- Introduction of a termination charge for international calls from other carriers, with a yield of 0.1 percent of GDP.

- $\quad$ Reduction of unbilled international traffic through the use of brokers $(0.1$ percent of GDP).

- $\quad$ Rebalancing of local tariffs (lowering domestic long distance and raising local); slowing down the growth of the wage bill in 2006 (to 10 percent, from 13 percent); and increasing fees from mobile networks, with a combined yield of 0.1 percent.

17. The authorities are strengthening tax administration, with assistance from the IDB and the U.S. Treasury. Recent measures include the reorganization of the tax and customs offices, a stricter definition of large taxpayers, and merit-based selection of customs officials. Looking forward, the authorities plan to improve coordination between the tax and customs offices, and to meet end-year targets for reducing stop-filers and increasing tax audits of large taxpayers (benchmark).

18. The authorities are planning a comprehensive pension reform, which would introduce a two-pillar system, including a basic pension scheme for all workers (pay-as-yougo) and a defined-contribution scheme with personal accounts. The authorities have agreed with the staff not to seek approval of the reform until after the election, providing time for a careful actuarial analysis of the sustainability of the proposed system.

\footnotetext{
${ }^{14}$ The revenue loss for Hondutel is about 0.7 percent of GDP, part of which is compensated by higher government fees collected from other market participants and higher sales taxes (0.2 percent). The approval of the telecommunications law would also generate revenues (by 0.1 percent of GDP) through additional fees from other market participants.
} 


\section{Monetary and Exchange Rate Issues}

19. The current stance of monetary policy appears broadly appropriate. The central bank has stepped up open market operations to sterilize large foreign exchange inflows (Box 3). In June 2005, annual currency growth was 16.9 percent while broad money and credit growth expanded by 19 percent and about 14 percent, respectively-slightly higher than programmed. Preliminary data for September 2005 suggest that annual currency growth has accelerated to about 23 percent on account of a low base (reflecting low growth in September 2004) and also to somewhat lower-than-expected sterilization in August 2005. The authorities increased their placements of central bank securities in September and believe that the monetary aggregates will approach program

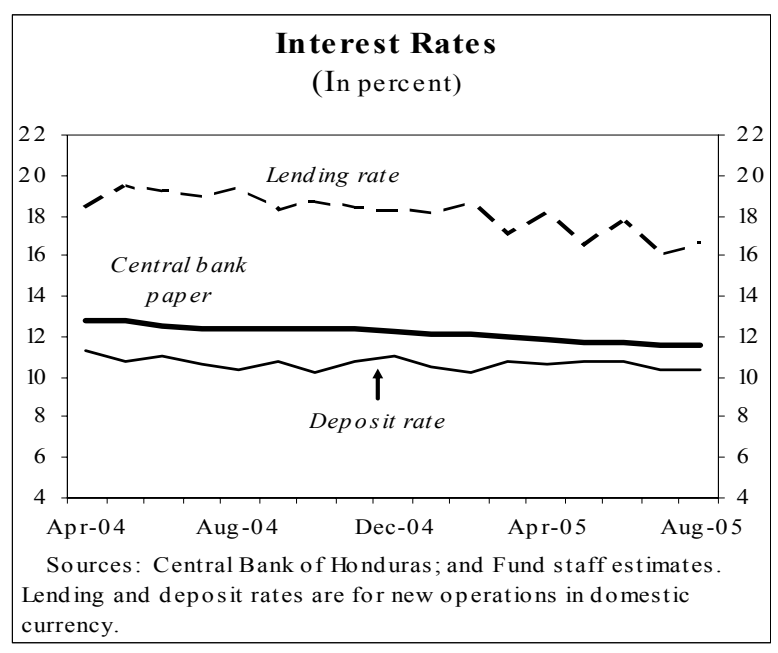
levels by end-year.

20. The authorities slowed down the rate of crawl of the exchange rate to contain inflation. In May 2005, they modified the formula of the rate of crawl by taking into account the level of NIR. As a result, the annual rate of crawl was lowered to about 1 percent (from 3 percent), which would lead to a 2 percent depreciation of the lempira for the year as a whole. The annual rate of crawl for 2006 will also average 2 percent. While supporting the authorities' short-term goal of containing inflation, staff reiterated the recommendation of gradually moving to a more flexible exchange rate system to reduce vulnerabilities. The authorities are laying the groundwork for greater flexibility through strengthening of monetary operations and prudential norms on foreign currency transactions.

\section{The slower rate of crawl has also contributed to somewhat containing}

sterilization costs. Sterilization costs have been rising owing to the strong foreign exchange inflows, limited exchange rate flexibility, and the authorities' efforts to manage liquidity. The staff supports the authorities' efforts to sterilize inflows as needed to contain liquidity, but notes the costs of sterilization remain a significant burden. ${ }^{15}$

${ }^{15}$ The quasi-fiscal deficit, which reflects the costs of sterilization, has hovered at around 1 percent of GDP in the last two years. 


\section{Box 3: Managing Liquidity from High Foreign Exchange Inflows}

In the context of strong foreign exchange inflows, the central bank's main tool to address higher liquidity has been sterilization through open market operations. Other tools included temporary higher reserve requirements, higher public sector deposits in the central bank, and a slowdown in the rate of crawl of the exchange rate.

The central bank has faced the challenge of managing liquidity from foreign exchange inflows. In June 2005, NIR reached US\$1.8 billion (22 percent of GDP), an increase of about US $\$ 0.5$ billion since June 2004. Foreign exchange inflows have grown steadily owing mostly to the rapid growth of family remittances (50 percent in June, y-o-y) and also to robust export growth (owing to improved coffee prices and good maquila performance).

Sterilization through stepped-up open market operations has been the main tool to address higher liquidity. Over half of the increase in international reserves has been sterilized through open market operations (about US\$300 million or about 4 percent of GDP). Despite the latter, central bank interest rates on the 180-day securities have fallen somewhat, to 11.7 percent in June 2005 (from 12.5 percent in June 2004). In addition, a temporary increase in (remunerated) reserve requirements of 2 percent of deposits was implemented in the second half of 2004. These requirements are scheduled to be phased out in the last quarter of 2005.

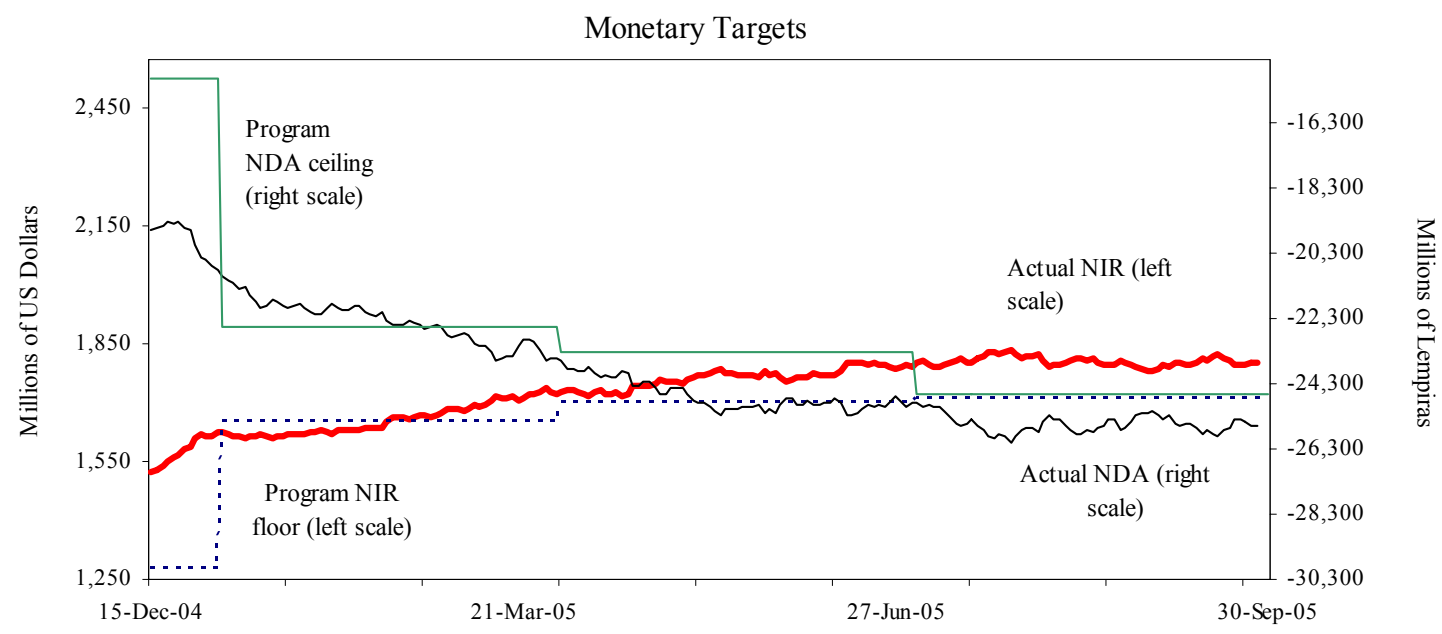

The accumulation of government deposits in the central bank also contributed to limiting the growth of currency. About one-fourth of the increased liquidity was offset by higher nonfinancial public sector deposits at the central bank (about US\$150 million or 2 percent of GDP), although about half of this effort was offset by a higher quasi-fiscal deficit. This accumulation - along with the sterilization and the obligatory investments - helped to control currency growth, despite the significant inflows: In June 2005, the annual growth rate was 16.9 percent (17.5 percent in June 2004).

The rate of depreciation under the crawl has been slowed. To contain inflationary pressures, and given the strong foreign exchange inflows, the authorities reduced the annual rate of crawl to about 1 percent in May 2005, from 3 percent. For 2005 as a whole, the depreciation of the lempira will average about 2 percent. 
22. Progress has been made in the reform of monetary operations. In May 2005, the central bank established an overnight interest rate corridor (structural benchmark), ${ }^{16}$ issued 7day central bank securities, and started bi-weekly auctions of 90-360 day securities to manage structural liquidity. The authorities will next address organizational changes, including the separation of the front-, middle- and back-office of the monetary operations department (benchmark), to prepare for the subsequent creation of a money desk. Obligatory investments in domestic currency (equal to 2 percent of total deposits) will be eliminated by end-November 2005, offset by open market operations. The scheduled capitalization of the central bank has been completed. ${ }^{17}$

\section{Financial Sector Reform}

23. In October 2005, the authorities started the reform of banks' liquidity and reserve requirements, which will be coupled with a strengthened prudential framework for banks' foreign currency operations. The authorities argue that Honduran banks face unfair competition from other banks operating in the region that are subject to much lower reserve and liquidity requirements. To begin to level the competitive field, the authorities intend to pursue the reform in the following sequence:

- $\quad$ Obligatory investments in domestic currency deposits (2 percent of total deposits) will be eliminated by end-November, and offset by open market operations.

- $\quad$ Enhanced prudential norms on banks' foreign currency operations will be implemented by end-December, requiring banks to hold additional capital for dollar loans to non-dollar earners and limiting banks' net open foreign exchange position (structural benchmark).

- Limits on banks' external indebtedness (at twice their capital) would be gradually lifted. ${ }^{18}$

\footnotetext{
${ }^{16}$ The current level of the corridor is $3-11$ percent, while interbank interest rates are hovering around 7 percent.

${ }^{17}$ The ministry of finance issued three bonds to cover the central bank losses during 19972004, including a 50-year bond to cover losses for 1997-2003, which bears no interest, with a 25-year grace period; a 25-year bond to cover 90 percent of the 2004 losses with a 10-year grace period ( 2 percent interest rate to be paid annually); and a 25 -year bond to cover the remaining losses for 2004, with a 10-year grace period, which yields the rate paid by central bank 180-day securities.

${ }^{18}$ The new prudential norms that will be implemented mitigate risks arising from this measure by moving to a risk-based approach.
} 
- $\quad$ Obligatory investments in foreign currency deposits (2 percent of total deposits) would be eliminated and liquidity requirements gradually lowered to regional levels and applied also to banks' foreign currency loans.

\begin{tabular}{|c|c|c|}
\hline \multicolumn{3}{|c|}{$\begin{array}{l}\text { Reserve and Liquidity Requirements on Deposits } \\
\text { (In percent) }\end{array}$} \\
\hline & $\begin{array}{l}\text { Domestic } \\
\text { Currency } \\
\end{array}$ & $\begin{array}{c}\text { Foreign } \\
\text { Currency }\end{array}$ \\
\hline Costa Rica & 15.00 & 15.00 \\
\hline \multicolumn{3}{|l|}{ El Salvador } \\
\hline Check and savings & NA & 25.00 \\
\hline Time deposits & NA & 20.00 \\
\hline Guatemala & 14.60 & 14.60 \\
\hline Honduras & 14.00 & 52.00 \\
\hline \multicolumn{3}{|l|}{ Of which: } \\
\hline Reserve requirements & 12.00 & 12.00 \\
\hline Liquidity requirements 1 / & 0.00 & 38.00 \\
\hline Obligatory investments 2 / & 2.00 & 2.00 \\
\hline Nicaragua & 16.25 & 16.25 \\
\hline \multicolumn{3}{|c|}{$\begin{array}{l}\text { 1/ The liquidity requirement on foreign currency deposits will be reduced to } 30 \text { percent following } \\
\text { the adoption of prudential regulations. }\end{array}$} \\
\hline
\end{tabular}

24. A three-year program is in effect to raise banks' loan provisions close to international standards by end-2006, relying heavily on retained earnings for financing. More broadly, the CNBS intends to enforce fully the enhanced legal and prudential framework approved last year.

\section{E. Financing Assurances}

25. The program is fully financed for 2005-06. Honduras has engaged in good faith efforts to resolve minor private arrears, the existence of which are not undermining program implementation. ${ }^{19}$ Following the May 2005 Paris Club renegotiation, bilateral agreements have been signed with Canada, Spain, and the United States, and only relief from these bilateral creditors has been included in the 2006 fiscal program.

\section{The Multilateral Debt Relief Initiative (MDRI) could have a sizable impact on}

Honduras. In NPV terms, the stock of external debt will fall by 23 percent, and annual debt service will decrease by about 0.5 percent of GDP in the next two years. ${ }^{20}$ The incremental resources freed by the MDRI are expected to be used to help achieve the Millennium Development Goals.

${ }^{19}$ Private creditor arrears, which amount to about US\$5 million, arose prior to the program, when some creditors did not participate in the earlier IDA repurchase offer. No request for payment has been received since the repurchase offer.

${ }^{20}$ This relief is not included in the draft 2006 budget. 


\begin{tabular}{|c|c|c|c|c|c|}
\hline \multicolumn{6}{|c|}{ Disbursements of External Loans 2004-06 } \\
\hline & \multirow{2}{*}{$\begin{array}{r}\text { Actual } \\
2004\end{array}$} & \multicolumn{2}{|c|}{2005} & \multicolumn{2}{|c|}{2006} \\
\hline & & Prog. & Rev.Prog. & Prog. & $\overline{\text { Rev.Prog. }}$ \\
\hline Total & 398 & 305 & 306 & 279 & 292 \\
\hline Program loans & 104 & 40 & 46 & 53 & 68 \\
\hline World Bank & 58 & 25 & 25 & 28 & 28 \\
\hline PRSC I & 58 & $\ldots$ & $\ldots$ & $\ldots$ & $\ldots$ \\
\hline FSAC & $\ldots$ & 25 & 25 & $\ldots$ & $\ldots$ \\
\hline PRSC II & $\ldots$ & $\ldots$ & $\ldots$ & 28 & 28 \\
\hline IDB & 45 & 15 & 15 & 25 & 40 \\
\hline PRS I & 15 & $\ldots$ & $\ldots$ & $\ldots$ & 15 \\
\hline PRS II & 15 & $\ldots$ & 15 & $\ldots$ & $\ldots$ \\
\hline Financial sector loan & 15 & $\ldots$ & $\ldots$ & 10 & 10 \\
\hline Public expenditure management & $\ldots$ & 15 & $\ldots$ & 15 & $\ldots$ \\
\hline Social sector loan & $\ldots$ & $\ldots$ & $\ldots$ & $\ldots$ & 15 \\
\hline Germany (KfW) & $\ldots$ & $\ldots$ & 6 & $\ldots$ & $\ldots$ \\
\hline Project loans & 294 & 265 & 259 & 226 & 224 \\
\hline Multilateral & 203 & 218 & 198 & 200 & 198 \\
\hline World Bank & 67 & 66 & 78 & 72 & 70 \\
\hline IDB & 93 & 98 & 69 & 92 & 92 \\
\hline CABEI & 35 & 26 & 27 & 28 & 28 \\
\hline Other & 8 & 27 & 24 & 8 & 8 \\
\hline Bilateral & 92 & 48 & 62 & 26 & 26 \\
\hline
\end{tabular}

\section{F. Program Modalities}

\section{Program targets for 2005 and 2006 and the structural agenda are shown in} Tables 1 and 2 of the Supplementary Memorandum of Economic Policies (Attachment II). Prior actions for this review include the submission to congress of a 2006 budget in line with the program, and identification of measures to offset the revenue losses due to telecom reform. Prior actions for the next (fourth) review-expected in April 2006will be the approval of a 2006 budget consistent with the program and the adoption of measures to offset the revenue loss of telecom reform. The elimination of price controls over basic foodstuffs has been added as a structural performance criterion for end-December 2005. New benchmarks for December 2005 refer to tax administration (further reduction of tax stop-filers and increase in audits of large taxpayers) and reform of the central bank (reorganization of the monetary operations department). The quantitative performance criterion on the deficit of the central government for end-December 2005 has been revised up slightly (by 0.2 percent of GDP or L 370 million) to accommodate the cost of the fuel freeze; and new quantitative performance criteria are proposed for June 2006, and indicative targets for March 2006, September 2006, and December 2006. 


\section{G. Other Issues}

28. Statistical issues. The authorities have joined the General Data Dissemination System (GDDS), and meta data were posted in September 2005. The data ROSC has been published.

\section{StAFF APPRAISAL}

29. The authorities are to be commended for steadfast implementation of their program despite difficult domestic conditions and higher oil prices. Program implementation reflects the authorities' strong ownership of the program, which is also evidenced by the prudent management of public finances through the first half of the year.

30. The program has continued to deliver results. Despite the surge in international oil prices, economic growth and the external position remain strong. Inflation has stabilized albeit at a higher level than anticipated. The authorities' program of structural reforms has led to improved control over the wage bill and tax administration, increased poverty spending and public investment, strengthened financial sector regulation and supervision, and the reform of monetary operations.

31. The staff welcomes the reintroduction of a flexible fuel price mechanism for most fuel products and stresses the importance of maintaining a flexible passthrough of international prices. The economy's adjustment to higher fuel prices has been facilitated by the existence of such a flexible fuel price mechanism. Looking forward, the staff urges the authorities to use a flexible pricing mechanism for all fuels; the incorporation of a stronger smoothing element in the adjustment mechanism would prevent sharp changes to domestic prices such as those following Hurricane Katrina.

32. The staff strongly supports the authorities' intention to allow price controls over basic foodstuffs to expire at end-2005 (performance criterion). Congress imposed these controls to protect the poor, particularly in noncompetitive product markets. Targeted subsidies, in line with the fiscal framework, as well as opening these markets to international competition, would be more effective to promote competition and protect vulnerable groups.

33. Resolute implementation of the medium-term fiscal strategy is essential. While telecom reform and CAFTA are expected to boost growth, the potential revenue losses need to be addressed. There is no room for slippage in the authorities' strategy to approve a prudent budget for 2006 and implement offsetting measures for Hondutel. The integration of teachers' benefits into their overall salary is needed to ensure a sustainable medium-term budget. $^{21}$ The new administration will need to garner domestic support to implement a sustainable public wage policy before the 2007 budget is approved (when the current

\footnotetext{
${ }^{21}$ Not integrating benefits would increase the wage bill by 0.8 percent of GDP in 2007 , according to preliminary data provided by the authorities, assuming that all eligible teachers receive their supplementary benefits but no retroactive adjustments are granted.
} 
arrangements limiting the growth of the wage bill expire). A sustainable medium-term fiscal strategy will also require prompt implementation of measures to address the financial situation at ENEE, including raising electricity tariffs, improving collections, eliminating tariff distortions, and lowering generation costs.

34. Further work is needed to consolidate reforms on tax administration and to complete reforms to public financial management. While progress has been made in the area of tax administration, more efforts are needed looking forward, including stepping up the number of audits of large taxpayers (structural benchmark), modernizing the audit function and increasing its effectiveness through objective procedures to select taxpayers, and using risk-based assessment techniques. In the area of financial management reform, the country has made notable progress after the adoption of a new organic budget law and multiyear budgeting documents. Further efforts should focus on improving the quality of the fiscal data and including an analysis of fiscal policy sustainability in budget documents.

35. The staff encourages the authorities to remain vigilant on the stance of monetary policy. While the stance has been broadly appropriate, the central bank should monitor liquidity and inflation developments carefully to avoid second round effects from the higher oil prices. Open market operations should continue to be the main instrument to fight inflation.

36. The staff welcomes the progress made in improving monetary operations. The establishment of an overnight interest rate corridor and the changes to the auctions of central bank securities are important steps forward. Looking ahead, the authorities are encouraged to allow for greater market determination of interest rates and to proceed with the organizational changes of the central bank to allow for the establishment of a money desk.

37. Although the crawling peg exchange rate serves as a useful anchor for inflation, it limits the economy's ability to adjust to external shocks. The authorities are making progress in strengthening monetary operations and the prudential framework - prerequisites for a move to a more flexible exchange rate system. The next administration will be well positioned to move toward a more flexible exchange rate system. The next step would be the phased elimination of foreign exchange surrender requirements.

38. The staff welcomes the authorities' efforts to improve the prudential framework for banks' foreign exchange operations. The staff supports the introduction of measures to control the risk of dollar lending to non-dollar earners and to limit the net open foreign exchange position of banks and urges their full enforcement. While addressing important financial sector vulnerabilities, these measures will also allow for the gradual reform of banks' liquidity requirements in foreign currency. This reform will help level the competitive playing field between Honduran banks and others in the region that face much lower requirements.

39. Despite considerable progress, additional reforms are needed to strengthen the financial sector's resiliency to shocks. The enhanced legal and prudential framework 
approved last year needs to be enforced fully along with the timetable for provisioning for nonperforming loans.

40. The staff supports the authorities' request for completion of the third review under the PRGF, including the waiver and the modification of PCs. The staff supports the waiver of the performance criterion on unfinanced appropriations on account of the authorities' corrective actions (offsetting expenditure cuts); and because the nonobservance was minor (amounting to less than 0.1 percent of GDP) and temporary (10 days). 
Table 1. Honduras: Selected Economic Indicators

Population

Per capita income (in U.S. dollars)

Rank in UNDP Development Index 2005

Life expectancy at birth in years (2003)

I. Social Indicators

7.0 million Adult literacy (ages 15 and above, 2003)

1,218 Percent of pop. below poverty line (2004)

80 percent

116 of 177 Gini index

68 Oil imports (2005 est.) US\$1,018 million

II. Economic Indicators

\begin{tabular}{lllllll}
\hline & & & Prel. & \multicolumn{2}{c}{ Proj. } \\
\cline { 4 - 6 } & 2001 & 2002 & 2003 & 2004 & 2006 \\
\hline
\end{tabular}

(Annual percentage change, unless otherwise indicated)

National income and prices

GDP at constant prices

GDP deflator

Consumer prices (end of period, eop)

Exchange rate (eop, depreciation -)

Lempiras per U.S. dollar

Real effective rate

Money and credit

Net domestic assets

Combined public sector credit

Private sector credit

Broad money

Lending rate (eop, in percent)

Deposit rate (eop, in percent)

Combined public sector

Noninterest revenue and grants

Noninterest expenditure

Primary balance

Net interest payments

Savings

Capital expenditure

Overall balance

External financing

Domestic financing

Savings and investment

Fixed capital formation

Gross national savings

$\begin{array}{rrrrrr}2.6 & 2.7 & 3.5 & 4.6 & 4.2 & 4.3 \\ 8.0 & 6.3 & 7.7 & 8.9 & 10.2 & 8.2 \\ 8.8 & 8.1 & 6.8 & 9.2 & 8.7 & 6.8 \\ & & & & & \\ -4.8 & -6.3 & -5.0 & -4.9 & \ldots & \ldots \\ 4.2 & -3.7 & -7.8 & -0.8 & \ldots & \ldots \\ & & & & & \\ 13.4 & 5.1 & 33.2 & 3.0 & 9.7 & 30.6 \\ 3.1 & -0.9 & 45.9 & -38.2 & -13.3 & -24.5 \\ 12.2 & 7.5 & 11.9 & 15.4 & 14.9 & 15.6 \\ 14.5 & 13.3 & 14.0 & 19.2 & 15.9 & 17.9 \\ 22.2 & 20.9 & 18.0 & 18.2 & \ldots & \ldots \\ 14.0 & 12.0 & 11.0 & 11.1 & \ldots & \ldots\end{array}$

(In percent of GDP)

$\begin{array}{rrrrrr}27.1 & 25.3 & 26.0 & 27.0 & 27.6 & 27.2 \\ 29.8 & 28.6 & 30.6 & 29.7 & 30.3 & 29.2 \\ -2.7 & -3.3 & -4.6 & -2.7 & -2.6 & -1.9 \\ 0.5 & 0.3 & 0.5 & 0.3 & -0.1 & -0.2 \\ 3.7 & 2.1 & 0.5 & 3.3 & 4.0 & 4.5 \\ 7.7 & 5.8 & 6.2 & 6.5 & 7.7 & 7.6 \\ \mathbf{- 3 . 2} & \mathbf{- 3 . 6} & \mathbf{- 5 . 1} & \mathbf{- 3 . 0} & \mathbf{- 2 . 5} & \mathbf{- 1 . 7} \\ 3.0 & 1.9 & 1.9 & 4.5 & 2.9 & 2.1 \\ 0.1 & 1.7 & 3.2 & -1.6 & -0.3 & -0.3 \\ & & & & & \\ 23.6 & 22.1 & 21.7 & 27.9 & 23.7 & 24.9 \\ 19.6 & 19.0 & 17.5 & 23.2 & 21.6 & 22.0\end{array}$

(In millions of U. S. dollars, unless otherwise indicated)

Balance of payments

Gross international reserves

(in months of imports) $1 /$

Change in net international reserves (increase -)

External current account balance (percent of GDP)

(excluding official transfers)

Exports, f.o.b. (annual percentage change)

Imports, f.o.b. (annual percentage change)

Public sector debt (in percent of GDP) 2/

Public sector external debt (in percent of GDP) 2/

Public sector external debt service (in percent

of exports of goods and services) 3 /

$\begin{array}{rrrrrr}1,414 & 1,523 & 1,430 & 1,936 & 2,218 & 2,395 \\ 4.9 & 5.2 & 4.5 & 4.5 & 4.6 & 4.8 \\ -80 & -129 & 77 & -496 & -282 & -177 \\ -4.1 & -3.1 & -4.2 & -4.7 & -2.1 & -2.9 \\ -10.4 & -7.2 & -7.5 & -7.7 & -5.5 & -6.5 \\ -4.3 & -0.8 & 1.5 & 15.3 & 10.1 & 4.6 \\ 3.7 & 1.3 & 9.2 & 20.4 & 16.6 & 13.8 \\ 75.2 & 75.5 & 75.3 & 73.3 & 55.4 & 52.5 \\ 70.7 & 70.8 & 69.8 & 68.2 & 50.9 & 48.4 \\ 6.3 & & & & & \\ & 7.8 & 8.2 & 6.1 & 4.4 & 4.0\end{array}$

Sources: Central Bank of Honduras; Ministry of Finance; and Fund staff estimates.

$1 /$ Refers to the following year's imports of nonmaquila goods and nonfactor services.

2/ Includes medium- and long-term public and publicly guaranteed external debt after HIPC and beyond HIPC debt relief.

3/ Debt service paid. 
Table 2. Honduras: Operations of the Central Government

(In percent of GDP)

\begin{tabular}{|c|c|c|c|c|c|c|c|}
\hline & \multirow[b]{2}{*}{2002} & \multirow[b]{2}{*}{2003} & \multirow[b]{2}{*}{2004} & \multicolumn{2}{|c|}{2005} & \multicolumn{2}{|c|}{2006} \\
\hline & & & & Prog. 1/ & Rev. & Prog. 1/ & Rev. \\
\hline Total revenue and grants & 19.4 & 19.6 & 20.5 & 21.1 & 21.2 & 19.8 & 20.8 \\
\hline Current revenue & 18.3 & 18.5 & 19.5 & 19.4 & 19.4 & 18.4 & 19.1 \\
\hline Tax revenue & 15.9 & 16.3 & & 17.4 & 17.5 & 17.0 & 17.2 \\
\hline Nontax revenue & 1.0 & 0.9 & 0.9 & 0.8 & 1.0 & 0.9 & 1.1 \\
\hline Transfers & 1.4 & 1.3 & 1.3 & 1.2 & 1.0 & 0.5 & 0.7 \\
\hline Grants & 1.1 & 1.1 & 0.9 & 1.8 & 1.7 & 1.4 & 1.7 \\
\hline Of which: HIPC relief 2/ & 0.5 & 0.1 & 0.1 & 0.5 & 0.5 & 0.6 & 0.7 \\
\hline Total expenditure & 24.7 & 25.7 & 24.0 & 24.1 & 24.4 & 23.5 & 23.3 \\
\hline Current expenditure & 18.8 & 19.8 & 18.1 & 18.0 & 18.6 & 17.2 & 17.5 \\
\hline Wages and salaries & 10.8 & 10.5 & 10.1 & 9.9 & 9.8 & 9.6 & 9.6 \\
\hline Goods and services & 2.4 & 2.2 & 2.2 & 2.6 & 2.7 & 2.5 & 2.4 \\
\hline Transfers 3/ & 3.8 & 5.1 & 4.0 & 3.8 & 4.5 & 3.7 & 4.2 \\
\hline Interest payments & 1.9 & 1.9 & 1.8 & 1.7 & 1.6 & 1.5 & 1.3 \\
\hline External 4/ & 1.6 & 1.6 & 1.3 & 1.2 & 1.1 & 1.1 & 0.9 \\
\hline Domestic & 0.3 & 0.3 & 0.4 & 0.4 & 0.4 & 0.4 & 0.3 \\
\hline Capital expenditure & 5.0 & 5.5 & 6.0 & 5.9 & 5.7 & 6.0 & 5.9 \\
\hline Fixed capital formation & 2.2 & 2.3 & 2.6 & 2.6 & 2.4 & 2.1 & 2.5 \\
\hline Transfers & 2.8 & 3.2 & 3.4 & 3.3 & 3.3 & 3.8 & 3.3 \\
\hline Net lending 5 / & 0.9 & 0.4 & 0.0 & 0.3 & 0.0 & 0.3 & 0.0 \\
\hline Public sector reorganization savings & $\ldots$ & $\ldots$ & 0.0 & 0.0 & 0.0 & 0.2 & 0.0 \\
\hline Additional needed measures $6 /$ & $\ldots$ & $\ldots$ & 0.0 & 0.0 & 0.0 & 1.1 & 0.0 \\
\hline Program balance & $\ldots$ & $\ldots$ & -3.5 & -3.0 & -3.2 & -2.5 & -2.5 \\
\hline Financing & 5.3 & 6.0 & 3.5 & 3.0 & 3.2 & 2.5 & 2.5 \\
\hline External financing & 1.8 & 1.7 & 4.6 & 2.0 & 2.9 & 1.3 & 2.3 \\
\hline Disbursements & 2.4 & 2.4 & 5.1 & 3.1 & 3.4 & 2.6 & 3.1 \\
\hline Amortization & -2.3 & -2.5 & -2.6 & -2.2 & -2.3 & -2.0 & -0.9 \\
\hline Zero coupon bonds & -0.1 & -0.1 & -0.1 & -0.1 & -0.1 & -0.1 & -0.1 \\
\hline Exceptional financing $7 /$ & 1.8 & 1.8 & 2.1 & 1.1 & 1.8 & 0.8 & 0.1 \\
\hline Domestic financing & 3.4 & 4.4 & -1.1 & 0.0 & 0.3 & 0.2 & 0.2 \\
\hline Financial system & 0.2 & 2.4 & -2.1 & 0.0 & 0.3 & 0.2 & 0.2 \\
\hline Bonds & 0.6 & 0.3 & 0.1 & 0.0 & 0.0 & 0.0 & 0.0 \\
\hline Extraordinary transfers $8 /$ & 2.3 & 1.2 & 0.4 & 0.0 & 0.0 & 0.0 & 0.0 \\
\hline Floating debt & 0.4 & 0.5 & 0.5 & 0.0 & 0.0 & 0.0 & 0.0 \\
\hline New domestic arrears & 0.0 & 0.0 & 0.0 & 0.0 & 0.0 & 0.0 & 0.0 \\
\hline Financing gap 9/ & $\ldots$ & $\ldots$ & 0.0 & 1.0 & 0.0 & 1.0 & 0.0 \\
\hline \multicolumn{8}{|l|}{ Memorandum items } \\
\hline \multicolumn{8}{|l|}{ PRSP spending } \\
\hline New definition & 7.5 & 7.5 & 8.4 & 8.7 & 8.7 & 9.4 & 9.4 \\
\hline Old definition & 2.4 & 2.5 & 3.8 & 3.8 & 3.8 & 4.5 & 4.5 \\
\hline
\end{tabular}

Sources: Ministry of Finance; Central Bank of Honduras; and Fund staff estimates.

1/ Second review (March 2005).

2/ Comprises HIPC interim relief from IBRD/IDA, IDB, and the Fund.

3/ Includes the fuel subsidy ( 0.2 percent of GDP) and the cost of support plan for agricultural loans (1 percent of GDP in 2003).

4/ On an accrual basis.

5/ Includes the cost of closing financial institutions: Solfisa and Banhcrecer in 2001; and Banco Capital in 2002

$(0.2,0.5$, and 0.5 percent of GDP, respectively).

6/ This includes revenue and expenditure measures needed to offset (potential) revenue losses from CAFTA and Hondutel transfers.

7/ Assumes all bilateral Paris Club agreements are signed by end-2005.

8/ From the state telephone company, Hondutel.

9/ To be covered with HIPC and beyond-HIPC debt relief following the HIPC completion point (April 2005). 
Table 3. Honduras: Operations of the Central Government - Quarterly (Cumulative)

(In millions of lempiras)

\begin{tabular}{|c|c|c|c|c|c|c|c|c|c|c|c|c|}
\hline & \multicolumn{8}{|c|}{2005} & \multicolumn{4}{|c|}{2006} \\
\hline & \multicolumn{2}{|c|}{$\mathrm{Q} 1$} & \multicolumn{2}{|c|}{$\mathrm{Q} 2$} & \multicolumn{2}{|c|}{$\mathrm{Q} 3$} & \multicolumn{2}{|c|}{$\mathrm{Q} 4$} & \multicolumn{4}{|c|}{ Revised } \\
\hline & $\begin{array}{l}\text { Prog. 1/ } \\
\end{array}$ & Actual & Prog. 1/ & $\overline{\text { Actual }}$ & Prog. 1/ & $\overline{R e v .}$ & Prog. 1/ & $\overline{\text { Rev. }}$ & Q1 & $\mathrm{Q} 2$ & Q3 & $\overline{\mathrm{Q} 4}$ \\
\hline Total revenue and grants & 7,034 & 6,659 & 15,996 & 15,855 & 24,093 & 23,930 & 32,200 & 32,544 & 7,187 & 17,414 & 26,338 & 35,860 \\
\hline Current revenue & 5,878 & 6,025 & 14,206 & 14,772 & 21,672 & 21,935 & 29,523 & 29,884 & 6,509 & 15,948 & 24,139 & 32,928 \\
\hline Tax revenue & 5,112 & 5,135 & 12,674 & 13,117 & 19,373 & 19,661 & 26,459 & 26,852 & 5,704 & 14,379 & 21,748 & 29,710 \\
\hline Nontax revenue & 314 & 426 & 627 & 877 & 941 & 1,156 & 1,255 & 1,542 & 549 & 936 & 1,429 & 1,981 \\
\hline Transfers & 453 & 465 & 905 & 777 & 1,358 & 1,118 & 1,810 & 1,490 & 256 & 633 & 963 & 1,237 \\
\hline Capital revenue & 0 & 16 & 0 & 21 & 0 & 1 & 0 & 0 & 0 & 0 & 0 & 0 \\
\hline Grants & 1,156 & 618 & 1,790 & 1,063 & 2,422 & 1,994 & 2,676 & 2,659 & 677 & 1,466 & 2,199 & 2,932 \\
\hline Of which: HIPC relief 2/ & 0 & 168 & 57 & 348 & 97 & 97 & 775 & 775 & 258 & 345 & 493 & 1,189 \\
\hline Total expenditure & 7,554 & 7,669 & 17,663 & 16,709 & 25,986 & 26,463 & 36,761 & 37,475 & 8,400 & 19,028 & 28,202 & 40,243 \\
\hline Current expenditure & 6,053 & 6,108 & 13,852 & 13,494 & 19,823 & 20,690 & 27,441 & 28,696 & 6,550 & 15,062 & 21,568 & 30,135 \\
\hline Wages and salaries & 3,299 & 2,919 & 7,455 & 7,104 & 10,841 & 10,841 & 15,149 & 15,149 & 3,599 & 8,481 & 11,846 & 16,663 \\
\hline Goods and services & 1,008 & 972 & 2,017 & 1,981 & 3,025 & 3,145 & 4,034 & 4,194 & 942 & 1,953 & 3,045 & 4,060 \\
\hline Transfers & 1,014 & 1,471 & 3,116 & 3,137 & 3,985 & 4,810 & 5,769 & 6,964 & 1,308 & 3,441 & 4,897 & 7,169 \\
\hline Interest payments & 732 & 746 & 1,264 & 1,272 & 1,973 & 1,893 & 2,489 & 2,389 & 701 & 1,187 & 1,780 & 2,243 \\
\hline External 3/ & 567 & 562 & 929 & 915 & 1,472 & 1,391 & 1,817 & 1,717 & 536 & 886 & 1,328 & 1,640 \\
\hline Domestic & 168 & 184 & 336 & 356 & 504 & 504 & 672 & 672 & 165 & 302 & 452 & 603 \\
\hline Capital expenditure & 1,397 & 1,577 & 3,601 & 3,345 & 5,848 & 5,774 & 8,902 & 8,779 & 1,850 & 3,966 & 6,634 & 10,108 \\
\hline Fixed capital formation & 758 & 387 & 1,575 & 1,025 & 2,724 & 2,599 & 3,927 & 3,747 & 495 & 1,251 & 3,014 & 4,343 \\
\hline Transfers & 639 & 1,190 & 2,027 & 2,320 & 3,124 & 3,175 & 4,975 & 5,056 & 1,355 & 2,715 & 3,621 & 5,765 \\
\hline Net lending & 105 & -15 & 210 & -130 & 314 & 0 & 419 & 0 & 0 & 0 & 0 & 0 \\
\hline Unidentified expenditure & 0 & 0 & 0 & 0 & 0 & 0 & 0 & 0 & 0 & 0 & 0 & 0 \\
\hline Required measures (savings) & 0 & 0 & 0 & 0 & 0 & 1 & 0 & 0 & 0 & 0 & 0 & 0 \\
\hline Overall balance & -520 & $-1,010$ & $-1,667$ & -854 & $-1,892$ & $-2,533$ & $-4,562$ & $-4,932$ & $-1,214$ & $-1,614$ & $-1,863$ & $-4,383$ \\
\hline Financing & 520 & 1,119 & 1,667 & 644 & 1,892 & 2,533 & 4,562 & 4,932 & 1,214 & 1,614 & 1,863 & 4,383 \\
\hline External financing & 467 & 450 & 1,272 & 1,789 & 2,003 & 3,228 & 3,007 & 4,442 & 640 & 1,451 & 2,535 & 3,975 \\
\hline Disbursements & 720 & 741 & 2,214 & 3,173 & 3,070 & 3,696 & 4,722 & 5,308 & 1,071 & 2,151 & 3,717 & 5,435 \\
\hline Amortization & -918 & $-1,019$ & $-1,719$ & $-2,966$ & $-2,573$ & $-2,967$ & $-3,331$ & $-3,480$ & -454 & -764 & $-1,275$ & $-1,592$ \\
\hline Zero coupon bonds & -42 & -42 & -42 & -42 & -87 & -86 & -88 & -87 & -46 & -46 & -92 & -93 \\
\hline Exceptional financing & 706 & 770 & 819 & 1,624 & 1,594 & 2,585 & 1,704 & 2,701 & 69 & 109 & 185 & 225 \\
\hline Domestic financing & 54 & 670 & -99 & $-1,144$ & $-1,134$ & -696 & 64 & 490 & 574 & 163 & -671 & 407 \\
\hline Financial system & 54 & 493 & -99 & -957 & $-1,134$ & -696 & 64 & 490 & 574 & 163 & -671 & 407 \\
\hline Bonds & 0 & 255 & 0 & 382 & 0 & 0 & 0 & 0 & 0 & 0 & 0 & 0 \\
\hline Extraordinary transfers $4 /$ & 0 & 0 & 0 & 0 & 0 & 0 & 0 & 0 & 0 & 0 & 0 & 0 \\
\hline Floating debt & 0 & -79 & 0 & -569 & 0 & 0 & 0 & 0 & 0 & 0 & 0 & 0 \\
\hline New domestic arrears & 0 & 0 & 0 & 0 & 0 & 0 & 0 & 0 & 0 & 0 & 0 & 0 \\
\hline Statistical discrepancy & $\ldots$ & 109 & $\ldots$ & -209 & $\ldots$ & $\ldots$ & $\ldots$ & $\ldots$ & $\ldots$ & $\ldots$ & $\ldots$ & $\ldots$ \\
\hline Financing gap 5/ & 0 & 0 & 495 & 0 & 1,023 & 1 & 1,490 & 0 & 0 & 0 & 0 & 0 \\
\hline Memorandum items: & 0 & 0 & 0 & 0 & 0 & 0 & 0 & 0 & 0 & 0 & 0 & \\
\hline PRSP spending & 3,317 & 3,070 & 6,634 & 6,762 & 9,950 & 9,950 & 13,267 & 13,267 & 4,058 & 8,116 & 12,175 & 16,233 \\
\hline
\end{tabular}

Sources: Ministry of Finance; Central Bank of Honduras; and Fund staff estimates

1/ Second review (March 2005).

3/ On an accrual basis.

5/ To be covered with HIPC and beyond-HIPC debt relief following the HIPC completion point (April 2005). 
Table 4. Honduras: Operations of the Combined Public Sector 1/

(In percent of GDP)

\begin{tabular}{|c|c|c|c|c|c|c|c|}
\hline & \multirow[b]{2}{*}{2002} & \multirow[b]{2}{*}{2003} & \multirow[b]{2}{*}{2004} & \multicolumn{2}{|c|}{2005} & \multicolumn{2}{|c|}{2006} \\
\hline & & & & Prog. 2/ & Rev. & Prog. 2/ & $\operatorname{Rev}$ \\
\hline Total revenue and grants & 26.9 & 27.4 & 28.7 & 29.4 & 29.4 & 27.9 & 28.9 \\
\hline Current revenue & 25.7 & 26.2 & 27.5 & 27.5 & 27.5 & 26.4 & 26.9 \\
\hline Tax revenue & 16.8 & 17.1 & 18.2 & 18.2 & 18.2 & 17.8 & 17.9 \\
\hline Nontax revenue 3 / & 4.8 & 5.1 & 5.0 & 5.1 & 5.1 & 5.3 & 5.2 \\
\hline Interest earnings & 1.6 & 1.5 & 1.8 & 1.6 & 1.7 & 1.7 & 1.7 \\
\hline Operating balance of public enterprises & 2.5 & 2.5 & 2.6 & 2.7 & 2.5 & 1.7 & 2.2 \\
\hline Capital revenue & 0.1 & 0.1 & 0.3 & 0.1 & 0.1 & 0.2 & 0.2 \\
\hline Grants & 1.1 & 1.1 & 1.0 & 1.8 & 1.7 & 1.4 & 1.7 \\
\hline Of which: HIPC 4/ & 0.5 & 0.1 & 0.1 & 0.5 & 0.5 & 0.6 & 0.7 \\
\hline Total expenditure & 30.5 & 32.5 & 31.7 & 32.0 & 31.9 & 31.0 & 30.6 \\
\hline Current expenditure & 23.6 & 25.7 & 24.1 & 23.2 & 23.5 & 22.5 & 22.4 \\
\hline Wages and salaries & 13.5 & 13.2 & 13.0 & 12.6 & 12.5 & 12.2 & 12.2 \\
\hline Goods and services & 3.4 & 3.2 & 3.3 & 3.7 & 3.7 & 3.7 & 3.4 \\
\hline Transfers 5/ & 2.5 & 4.2 & 2.8 & 3.0 & 3.5 & 2.8 & 3.2 \\
\hline Operating losses of the central bank & 0.9 & 1.1 & 1.1 & 1.1 & 1.0 & 1.0 & 1.3 \\
\hline Interest payments & 2.0 & 1.9 & 2.1 & 1.7 & 1.7 & 1.7 & 1.4 \\
\hline External 6/ & 1.6 & 1.6 & 1.3 & 1.2 & 1.1 & 1.1 & 1.0 \\
\hline Domestic & 0.3 & 0.4 & 0.7 & 0.5 & 0.6 & 0.5 & 0.5 \\
\hline Other $7 /$ & 1.2 & 2.0 & 1.9 & 1.1 & 1.2 & 1.1 & 1.0 \\
\hline Capital expenditure & 5.8 & 6.2 & 6.5 & 7.8 & 7.7 & 7.2 & 7.6 \\
\hline Fixed capital formation & 5.3 & 5.9 & 5.9 & 6.7 & 6.6 & 6.0 & 6.6 \\
\hline Transfers & 0.4 & 0.2 & 0.6 & 1.0 & 1.0 & 1.1 & 0.9 \\
\hline Other capital expenditure & 0.1 & 0.0 & 0.0 & 0.0 & 0.0 & 0.1 & 0.0 \\
\hline Net lending & 1.1 & 0.7 & 1.0 & 1.1 & 0.8 & 1.2 & 0.6 \\
\hline Public sector reorganization savings & $\ldots$ & $\ldots$ & 0.0 & 0.0 & 0.0 & 0.2 & 0.0 \\
\hline Additional needed measures $8 /$ & $\cdots$ & $\cdots$ & 0.0 & 0.0 & 0.0 & 0.0 & 0.0 \\
\hline Program balance & -3.6 & -5.1 & -3.0 & -2.5 & -2.5 & -1.7 & -1.7 \\
\hline Financing & 3.6 & 5.1 & 3.0 & 2.5 & 2.5 & 1.7 & 1.7 \\
\hline External financing & 1.9 & 1.9 & 4.5 & 1.9 & 2.9 & 1.2 & 2.1 \\
\hline Disbursements & 2.5 & 2.7 & 5.4 & 3.3 & 3.8 & 2.7 & 3.3 \\
\hline Amortization & -2.4 & -2.6 & -3.1 & -2.2 & -2.3 & -2.1 & -1.2 \\
\hline Zero coupon bonds & -0.1 & -0.1 & -0.1 & -0.1 & -0.1 & -0.1 & -0.1 \\
\hline Exceptional financing 9/ & 1.8 & 1.8 & 2.3 & 0.8 & 1.5 & 0.6 & 0.0 \\
\hline Domestic financing & 1.7 & 3.2 & -1.6 & -0.4 & -0.3 & -0.8 & -0.3 \\
\hline Banking system & -1.0 & 3.6 & -1.6 & -0.4 & -0.3 & -0.8 & -0.7 \\
\hline Bonds & 0.3 & 0.1 & 0.0 & 0.0 & 0.0 & 0.0 & 0.0 \\
\hline Deposits abroad 10/ & 2.0 & -0.2 & -0.2 & 0.0 & 0.0 & 0.0 & 0.0 \\
\hline Floating debt & 0.5 & -0.3 & 0.2 & 0.0 & 0.0 & 0.0 & 0.0 \\
\hline Financing gap 11/ & $\ldots$ & $\ldots$ & 0.0 & 1.0 & 0.0 & 1.3 & 0.0 \\
\hline
\end{tabular}

Sources: Ministry of Finance; Central Bank of Honduras; and Fund staff estimates.

1/ Includes the nonfinancial public sector and the quasi-fiscal deficit of the central bank.

2/ Second review (March 2005).

$3 /$ Includes contributions to the social security system.

4/ Comprises HIPC interim relief from IBRD/IDA, IDB, and the Fund

5/ Includes the fuel subsidy (0.2 precent of GDP) and the cost of support plan for agricultural loans (1 percent of GDP in 2003).

6/ On an accrual basis.

7/ Includes statistical discrepancy due to transfers from central government to the rest of general government.

8/ This includes revenue and expenditure measures needed to offset revenue losses from CAFTA and Hondutel transfers.

9/ Assumes all bilateral Paris Club agreements are signed by end-2005.

10 / Includes the change in deposits of the state telephone company held abroad.

11/ To be covered with HIPC and beyond-HIPC debt relief following the HIPC completion point (April 2005). 
Table 5. Honduras: Operations of the Combined Public Sector - Quarterly (Cumulative) 1/

(In millions of lempiras, cumulative since the beginning of the year)

\begin{tabular}{|c|c|c|c|c|c|c|c|c|c|c|c|c|}
\hline & \multicolumn{8}{|c|}{2005} & \multirow{2}{*}{\multicolumn{4}{|c|}{$\begin{array}{c}2006 \\
\text { Revised }\end{array}$}} \\
\hline & \multicolumn{2}{|c|}{ Q1 } & \multicolumn{2}{|c|}{$\mathrm{Q} 2$} & \multicolumn{2}{|c|}{$\mathrm{Q} 3$} & \multicolumn{2}{|c|}{$\mathrm{Q} 4$} & & & & \\
\hline & $\begin{array}{l}\text { Prog. 2/ } \\
\end{array}$ & Actual & Prog. 2/ & Actual & Prog. 2/ & $\overline{\text { Rev. }}$ & $\overline{\text { Prog. } 2 /}$ & $\overline{\text { Rev. }}$ & \multicolumn{4}{|c|}{\begin{tabular}{ll}
\multicolumn{2}{c}{ Revised } \\
Q2
\end{tabular}} \\
\hline Total revenue and grants & 10,198 & 9,709 & 22,282 & 21,725 & 33,595 & 33,850 & 44,870 & 45,220 & 10,467 & 23,265 & 36,564 & 49,849 \\
\hline Current revenue & 8,984 & 8,981 & 20,425 & 20,444 & 31,000 & 31,271 & 41,963 & 42,330 & 9,719 & 21,669 & 34,137 & 46,493 \\
\hline Tax revenue & 5,417 & 5,585 & 13,289 & 13,571 & 20,297 & 20,489 & 27,692 & 27,955 & 6,096 & 14,781 & 22,698 & 30,994 \\
\hline Nontax revenue $3 /$ & 1,954 & 1,659 & 3,908 & 3,598 & 5,862 & 5,853 & 7,817 & 7,804 & 2,054 & 3,950 & 6,485 & 8,914 \\
\hline Interest earnings & 598 & 579 & 1,196 & 1,325 & 1,793 & 2,016 & 2,391 & 2,688 & 576 & 1,232 & 2,042 & 2,851 \\
\hline Operating balance of public enterprises & 1,016 & 1,157 & 2,032 & 1,950 & 3,048 & 2,913 & 4,064 & 3,884 & 993 & 1,706 & 2,912 & 3,734 \\
\hline Capital revenue & 54 & 108 & 109 & 213 & 163 & 163 & 217 & 217 & 66 & 122 & 216 & 408 \\
\hline Grants & 1,159 & 620 & 1,748 & 1,067 & 2,432 & 2,416 & 2,690 & 2,673 & 681 & 1,474 & 2,211 & 2,948 \\
\hline Of which: HIPC 4/ & 0 & 168 & 59 & 348 & 101 & 101 & 808 & 808 & 258 & 345 & 493 & 1,189 \\
\hline Total expenditure & 10,878 & 10,057 & 24,034 & 21,566 & 35,187 & 35,597 & 48,730 & 49,143 & 12,847 & 25,125 & 37,054 & 52,855 \\
\hline Current expenditure & 8,335 & 8,188 & 17,675 & 17,508 & 25,995 & 26,700 & 35,394 & 36,183 & 9,039 & 18,596 & 28,180 & 38,704 \\
\hline Wages and salaries & 4,169 & 3,726 & 9,549 & 8,919 & 13,727 & 13,727 & 19,182 & 19,182 & 4,586 & 10,506 & 15,062 & 21,048 \\
\hline Goods and services & 1,398 & 1,292 & 2,797 & 2,787 & 4,195 & 4,212 & 5,593 & 5,616 & 1,451 & 2,321 & 4,352 & 5,802 \\
\hline Transfers & 1,140 & 1,067 & 2,281 & 2,258 & 3,421 & 3,984 & 4,562 & 5,312 & 1,093 & 2,456 & 4,002 & 5,465 \\
\hline Operating losses of the central bank & 438 & 564 & 875 & 883 & 1,313 & 1,312 & 1,750 & 1,588 & 800 & 1,200 & 1,659 & 2,245 \\
\hline Interest payments & 769 & 850 & 1,332 & 1,376 & 2,078 & 2,040 & 2,625 & 2,585 & 699 & 1,164 & 1,875 & 2,503 \\
\hline External 5/ & 567 & 572 & 929 & 927 & 1,472 & 1,367 & 1,817 & 1,687 & 522 & 834 & 1,341 & 1,672 \\
\hline Domestic & 202 & 278 & 404 & 449 & 606 & 673 & 808 & 898 & 178 & 334 & 537 & 832 \\
\hline Other $6 /$ & 420 & 689 & 841 & 1,285 & 1,261 & 1,425 & 1,682 & 1,900 & 410 & 950 & 1,230 & 1,641 \\
\hline Capital expenditure & 2,141 & 1,580 & 5,555 & 3,823 & 7,987 & 8,030 & 11,729 & 11,804 & 3,547 & 6,041 & 8,108 & 13,167 \\
\hline Fixed capital formation & 1,950 & 1,145 & 4,990 & 3,173 & 7,023 & 6,986 & 10,183 & 10,128 & 3,294 & 5,293 & 6,993 & 11,456 \\
\hline Transfers & 173 & 425 & 529 & 635 & 909 & 990 & 1,473 & 1,604 & 224 & 709 & 1,023 & 1,632 \\
\hline Other capital expenditure & 18 & 10 & 37 & 16 & 55 & 55 & 73 & 73 & 29 & 39 & 92 & 79 \\
\hline Net lending & 402 & 288 & 803 & 234 & 1,205 & 867 & 1,607 & 1,156 & 261 & 488 & 766 & 985 \\
\hline Required measures (savings) & $\mathbf{0}$ & $\mathbf{0}$ & $\mathbf{0}$ & $\mathbf{0}$ & $\mathbf{0}$ & 1 & $\mathbf{0}$ & $\mathbf{0}$ & $\mathbf{0}$ & $\mathbf{0}$ & $\mathbf{0}$ & $\mathbf{0}$ \\
\hline Overall balance & -680 & -348 & $-1,752$ & 159 & $-1,592$ & $-1,746$ & $-3,859$ & $-3,923$ & $-2,381$ & $-1,860$ & -490 & $-3,007$ \\
\hline Financing & 680 & 306 & 1,752 & -557 & 1,592 & 1,746 & 3,859 & 3,923 & 2,381 & 1,860 & 490 & 3,007 \\
\hline External & 456 & 375 & 1,105 & 1,697 & 1,900 & 3,170 & 2,877 & 4,459 & 487 & 1,139 & 2,062 & 3,571 \\
\hline Disbursements & 813 & 777 & 2,401 & 3,243 & 3,352 & 4,042 & 5,087 & 5,832 & 1,071 & 2,151 & 3,717 & 5,669 \\
\hline Amortization & -936 & $-1,132$ & $-1,742$ & $-3,130$ & $-2,621$ & $-3,022$ & $-3,387$ & $-3,539$ & -544 & -972 & $-1,578$ & $-2,020$ \\
\hline Zero coupon bonds & -42 & -42 & -42 & -42 & -87 & -86 & -88 & -87 & -46 & -46 & -92 & -93 \\
\hline Exceptional financing & 622 & 772 & 489 & 1,625 & 1,255 & 2,237 & 1,265 & 2,254 & 5 & 5 & 15 & 15 \\
\hline Domestic & 224 & -69 & 149 & $-2,254$ & $-1,349$ & $-1,425$ & -532 & -536 & 1,894 & 721 & $-1,572$ & -564 \\
\hline Banking system & 224 & -72 & 149 & $-1,716$ & $-1,349$ & $-1,425$ & -532 & -536 & 1,894 & 721 & $-1,572$ & -564 \\
\hline Bonds & 0 & 144 & 0 & 255 & 0 & 0 & 0 & 0 & 0 & 0 & 0 & 0 \\
\hline Deposits abroad 7/ & 0 & -454 & 0 & -411 & 0 & 0 & 0 & 0 & 0 & 0 & 0 & 0 \\
\hline Floating debt & 0 & 314 & 0 & -381 & 0 & 0 & 0 & 0 & 0 & 0 & 0 & 0 \\
\hline Financing gap 8/ & $\mathbf{0}$ & $\mathbf{0}$ & 498 & $\mathbf{0}$ & 1,041 & $\mathbf{0}$ & 1,514 & $\mathbf{0}$ & $\mathbf{0}$ & $\mathbf{0}$ & $\mathbf{0}$ & $\mathbf{0}$ \\
\hline
\end{tabular}

1/ Includes the nonfinancial public sector and the quasi-fiscal deficit of the central bank.

2) Second review (March 2005).

4/ Comprises HIPC interim relief from IBRD/IDA, IDB, and the Fund.

5/ On an accrual basis.

7/ Includes statistical discrepancy due to transfers from central government to the rest of general government.

8/ To be covered with HIPC and beyond-HIPC debt relief following the HIPC completion point (April 2005). 
Table 6. Honduras: Summary Accounts of the Banking System

(End of period; foreign currency accounts valued at end-of-period exchange rate)

\begin{tabular}{|c|c|c|c|c|c|c|c|c|}
\hline & \multirow[b]{3}{*}{2002} & \multirow[b]{3}{*}{2003} & \multirow[b]{3}{*}{2004} & \multicolumn{4}{|c|}{2005} & \multirow{3}{*}{$\begin{array}{r}\text { Rev } \\
2006\end{array}$} \\
\hline & & & & \multicolumn{2}{|c|}{ June } & \multicolumn{2}{|c|}{ December } & \\
\hline & & & & Prog.1/ & Actual & Prog.1/ & $\frac{\mathrm{Rev} .}{\mathrm{R}}$ & \\
\hline \multicolumn{9}{|c|}{ (In millions of lempiras) } \\
\hline \multicolumn{9}{|c|}{ I. Central Bank } \\
\hline Net international reserves & 20,385 & 20,009 & 30,240 & 32,207 & 33,851 & 35,178 & 36,106 & 40,235 \\
\hline (In millions of U.S. dollars) & 1,205 & 1,127 & 1,623 & 1,703 & 1,794 & 1,833 & 1,905 & 2,082 \\
\hline Net domestic assets & $-13,400$ & $-11,952$ & $-20,861$ & $-23,379$ & $-24,908$ & $-24,580$ & $-25,188$ & $-27,724$ \\
\hline Credit to the public sector (net) & $-7,676$ & $-4,898$ & $-7,100$ & $-7,021$ & $-7,156$ & $-7,636$ & $-5,919$ & $-4,102$ \\
\hline Combined nonfinancial public sector & $-9,584$ & $-8,151$ & $-11,819$ & $-12,615$ & $-12,758$ & $-14,105$ & $-12,226$ & $-12,654$ \\
\hline Central government & $-2,934$ & $-1,996$ & $-4,611$ & $-4,660$ & $-4,543$ & $-4,556$ & $-4,025$ & $-3,537$ \\
\hline Credit & 919 & 2,296 & 1,182 & 1,194 & 1,053 & 1,168 & 1,031 & 906 \\
\hline Liabilities & $-3,853$ & $-4,292$ & $-5,792$ & $-5,854$ & $-5,596$ & $-5,724$ & $-5,056$ & $-4,443$ \\
\hline Rest of nonfinancial public sector & $-6,650$ & $-6,155$ & $-7,208$ & $-7,955$ & $-8,215$ & $-9,548$ & $-8,201$ & $-9,117$ \\
\hline Credit & 33 & 29 & 26 & 28 & 24 & 34 & 29 & 33 \\
\hline Liabilities & $-6,683$ & $-6,185$ & $-7,234$ & $-7,983$ & $-8,239$ & $-9,583$ & $-8,230$ & $-9,149$ \\
\hline Cumulative operating losses of the central bank & 1,908 & 3,254 & 4,719 & 5,594 & 5,602 & 6,469 & 6,307 & 8,552 \\
\hline Rest of the banking system & $-8,698$ & $-8,284$ & $-14,055$ & $-16,786$ & $-17,348$ & $-17,492$ & $-18,912$ & $-24,044$ \\
\hline Of which: open market operations & $-4,514$ & $-4,626$ & $-8,240$ & $-11,217$ & $-11,750$ & $-11,519$ & $-14,542$ & $-18,570$ \\
\hline Private sector & $-1,217$ & $-2,273$ & $-2,791$ & $-2,867$ & $-3,527$ & $-2,944$ & $-3,276$ & $-3,833$ \\
\hline Medium- and long-term net foreign liabilities & $-2,871$ & $-2,743$ & $-2,566$ & $-2,546$ & $-2,536$ & $-2,524$ & $-2,464$ & $-2,350$ \\
\hline Other & 7,063 & 6,245 & 5,651 & 5,841 & 5,659 & 6,017 & 5,383 & 6,605 \\
\hline Currency issue & 6,985 & 8,056 & 9,379 & 8,828 & 8,943 & 10,598 & 10,917 & 12,511 \\
\hline \multicolumn{9}{|c|}{ II. Financial System } \\
\hline Net short-term foreign assets & 30,819 & 30,756 & 41,611 & 44,973 & 47,121 & 46,981 & 50,181 & $\mathbf{5 4 , 8 3 8}$ \\
\hline (In millions of U.S. dollars) & 1,821 & 1,733 & 2,233 & 2,378 & 2,498 & 2,448 & 2,648 & 2,838 \\
\hline Net domestic assets & 22,898 & 30,497 & 31,417 & 31,492 & 31,129 & 35,897 & 34,467 & 45,000 \\
\hline Combined public sector & $-10,593$ & $-5,730$ & $-7,916$ & $-7,767$ & $-9,462$ & $-8,448$ & $-6,864$ & $-5,184$ \\
\hline Combined nonfinancial public sector & $-12,501$ & $-8,984$ & $-12,635$ & $-13,361$ & $-15,064$ & $-14,917$ & $-13,171$ & $-13,736$ \\
\hline Credit to the private sector & 43,076 & 48,209 & 55,619 & 61,246 & 58,940 & 65,188 & 63,894 & 73,862 \\
\hline Local currency & 33,364 & 35,579 & 38,447 & 42,151 & 40,465 & 44,063 & 43,675 & 50,095 \\
\hline Foreign currency & 9,712 & 12,630 & 17,172 & 19,095 & 18,475 & 21,125 & 20,220 & 23,767 \\
\hline Medium- and long-term net foreign liabilities & $-5,994$ & $-5,770$ & $-6,978$ & $-6,689$ & $-7,213$ & $-6,667$ & $-7,249$ & $-7,375$ \\
\hline Other & $-3,591$ & $-6,212$ & $-9,308$ & $-15,298$ & $-11,135$ & $-14,176$ & $-15,315$ & $-16,303$ \\
\hline Broad money (M4) & 53,717 & 61,253 & 73,027 & 76,465 & $\mathbf{7 8 , 2 5 0}$ & 82,878 & 84,648 & 99,838 \\
\hline CAMs held by nonfinancial private sector & 950 & 1,920 & 2,497 & 2,572 & 2,884 & 2,650 & 2,770 & 3,703 \\
\hline Money including FC deposits (M3) & 52,767 & 59,333 & 70,531 & 73,893 & 75,366 & 80,228 & 81,878 & 96,136 \\
\hline Foreign currency deposits & 16,281 & 18,686 & 22,648 & 24,351 & 24,033 & 25,597 & 25,625 & 29,092 \\
\hline Money and quasi-money (M2) & 36,486 & 40,647 & 47,883 & 49,541 & 51,333 & 54,631 & 56,253 & 67,044 \\
\hline Time and savings deposits & 23,304 & 24,867 & 30,398 & 33,099 & 33,824 & 34,858 & 35,497 & 42,516 \\
\hline Money (M1) & 13,182 & 15,781 & 17,485 & 16,442 & 17,509 & 19,772 & 20,756 & 24,528 \\
\hline \multicolumn{9}{|c|}{ (12-month percentage change) } \\
\hline Currency in circulation & 7.2 & 16.9 & 18.5 & 16.4 & 17.4 & 13.8 & 17.5 & 16.5 \\
\hline Broad money & 13.3 & 14.0 & 19.2 & 16.3 & 19.0 & 13.5 & 15.9 & 17.9 \\
\hline Liabilities in lempiras & 11.7 & 11.4 & 17.8 & 16.3 & 20.5 & 14.1 & 17.5 & 19.2 \\
\hline Liabilities in foreign currency & 18.0 & 14.8 & 21.2 & 16.4 & 14.9 & 13.0 & 13.1 & 13.5 \\
\hline Credit to the private sector & 7.5 & 11.9 & 15.4 & 18.7 & 14.2 & 17.2 & 14.9 & 15.6 \\
\hline Credit in lempiras & 7.0 & 6.6 & 8.1 & 14.5 & 9.9 & 14.6 & 13.6 & 14.7 \\
\hline Credit in foreign currency & 9.2 & 30.0 & 36.0 & 29.3 & 25.1 & 23.0 & 17.7 & 17.5 \\
\hline \multicolumn{9}{|l|}{ Memorandum items: } \\
\hline$(\mathrm{EoPs}$ & $\mathrm{r}$ in percen & GDP, ex & pt when in & cated othe & & & & \\
\hline Currency in circulation & 5.1 & 5.3 & 5.6 & 4.7 & 4.7 & 5.7 & 5.8 & 6.1 \\
\hline Broad money & 49.7 & 50.8 & 53.6 & 50.1 & 50.9 & 54.3 & 55.0 & 57.8 \\
\hline Credit to the private sector & 39.8 & 40.0 & 40.8 & 40.2 & 38.3 & 42.7 & 41.5 & 42.8 \\
\hline Open market operations & 11.2 & 11.5 & 12.8 & 13.8 & 14.3 & 14.5 & 16.4 & 17.4 \\
\hline $\begin{array}{l}\text { Annual operating losses of central bank } \\
\text { (in millions of lempiras) }\end{array}$ & 1,026 & 1,346 & 1,465 & 875 & 883 & 1,750 & 1,588 & 2,245 \\
\hline
\end{tabular}

Sources: Central Bank of Honduras; and Fund staff estimates.

1/ Second review. 
Table 7. Honduras: Summary Accounts of the Central Bank

(End-of-period stocks, in millions of lempiras)

\begin{tabular}{|c|c|c|c|c|c|c|c|c|c|c|c|c|c|c|}
\hline & & & \multicolumn{8}{|c|}{2005} & \multirow{2}{*}{\multicolumn{4}{|c|}{$\begin{array}{c}2006 \\
\text { Program }\end{array}$}} \\
\hline & \multicolumn{2}{|c|}{ Dec. 2004} & \multicolumn{2}{|c|}{ Mar. } & \multicolumn{2}{|c|}{ Jun. } & \multicolumn{2}{|c|}{ Sep. } & \multicolumn{2}{|c|}{ Dec. } & & & & \\
\hline & Prog. 1/ & Actual & Prog. 1/ & Actual & Prog. 1/ & Actual & Prog. 1/ & Prel. & Prog. 1/ & Rev. & Mar. & Jun. & Sep. & Dec. \\
\hline Net international reserves & 23,964 & 30,240 & 31,030 & 32,391 & 32,207 & 33,851 & 32,635 & 34,417 & 35,178 & 36,106 & 36,759 & 37,895 & 38,080 & 40,235 \\
\hline (In millions of U.S. dollars) & 1,277 & 1,623 & 1,653 & 1,724 & 1,703 & 1,794 & 1,713 & 1,822 & 1,833 & 1,905 & 1,930 & 1,980 & 1,980 & 2,082 \\
\hline Net domestic assets & $-14,963$ & $-20,861$ & $-22,590$ & $-23,554$ & $-23,379$ & $-24,908$ & $-24,632$ & $-25,833$ & $-24,580$ & $-25,188$ & $-26,508$ & $-27,566$ & $-28,624$ & $-27,724$ \\
\hline Combined public sector & $-6,139$ & $-7,100$ & $-7,047$ & $-6,901$ & $-7,021$ & $-7,156$ & $-7,540$ & $-7,364$ & $-7,636$ & $-5,919$ & $-3,682$ & $-4,172$ & $-5,481$ & $-4,102$ \\
\hline Nonfinancial public sector & $-11,031$ & $-11,819$ & $-12,203$ & $-12,183$ & $-12,615$ & $-12,758$ & $-13,571$ & $-13,236$ & $-14,105$ & $-12,226$ & $-10,789$ & $-11,679$ & $-13,418$ & $-12,654$ \\
\hline $\begin{array}{l}\text { Cumulative losses of } \\
\text { central bank }\end{array}$ & 4,892 & 4,719 & 5,156 & 5,283 & 5,594 & 5,602 & 6,031 & 5,872 & 6,469 & 6,307 & 7,107 & 7,507 & 7,938 & 8,552 \\
\hline $\begin{array}{l}\text { Rest of the banking sector } \\
\text { Of which }\end{array}$ & $-9,145$ & $-14,055$ & $-15,580$ & $-15,963$ & $-16,786$ & $-17,348$ & $-17,247$ & $-18,385$ & $-17,492$ & $-18,912$ & $-22,648$ & $-23,320$ & $-23,500$ & $-24,044$ \\
\hline Open market operations & $-5,754$ & $-8,240$ & $-10,090$ & $-10,057$ & $-11,217$ & $-11,750$ & $-11,697$ & $-11,751$ & $-11,519$ & $-14,542$ & $-18,068$ & $-18,595$ & $-18,729$ & $-18,570$ \\
\hline Private sector & $-2,832$ & $-2,791$ & $-3,133$ & $-3,357$ & $-2,867$ & $-3,527$ & $-3,209$ & $-3,436$ & $-2,944$ & $-3,276$ & $-3,928$ & $-4,126$ & $-3,909$ & $-3,833$ \\
\hline $\begin{array}{l}\text { Medium- and long-term } \\
\text { foreign liabilities (net) }\end{array}$ & & & & & & & & & & & & & & \\
\hline Currency issue & 9,001 & 9,379 & 8,440 & $\mathbf{8 , 8 3 7}$ & 8,828 & 8,943 & 8,004 & 8,584 & 10,598 & 10,917 & 10,251 & 10,330 & 9,455 & 12,511 \\
\hline
\end{tabular}

Sources: Central Bank of Honduras; and Fund staff estimates.

1/ Second review. 
Table 8. Honduras: Structure and Performance of Banking Sector

(In percent, unless otherwise indicated)

\begin{tabular}{|c|c|c|c|c|c|}
\hline & 2001 & 2002 & 2003 & 2004 & $\begin{array}{l}\text { June } \\
2005\end{array}$ \\
\hline Total assets (in millions of lempiras) $2 /$ & 66,923 & 75,118 & 89,386 & 106,020 & 115,282 \\
\hline (In percent of GDP) & 68 & 69 & 74 & 78 & 85 \\
\hline Number of banks & 21 & 19 & 16 & 16 & 16 \\
\hline \multicolumn{6}{|l|}{ Of which } \\
\hline In process of liquidation or taken over & 1 & 1 & 0 & 0 & 0 \\
\hline Domestic & 19 & 17 & 10 & 9 & 9 \\
\hline Foreign & 2 & 2 & 6 & 7 & 7 \\
\hline \multicolumn{6}{|l|}{ Bank concentration } \\
\hline \multicolumn{6}{|l|}{ Number of banks accounting for at least } \\
\hline 25 percent of total assets & 2 & 2 & 2 & 2 & 2 \\
\hline 75 percent of total assets & 8 & 7 & 6 & 6 & 6 \\
\hline \multicolumn{6}{|l|}{ Bank rating (CAMEL) } \\
\hline Number of banks (Category IV and V) & 5 & 3 & 2 & 1 & 1 \\
\hline Share of total assets & 17 & 15 & 11 & 8 & 2 \\
\hline \multicolumn{6}{|l|}{ Capital adequacy } \\
\hline Regulatory capital to risk-weighted assets & 12.7 & 12.9 & 13.0 & 14.5 & 14.8 \\
\hline Capital (net worth) to assets & 9.2 & 8.1 & 7.6 & 8.4 & 8.5 \\
\hline \multicolumn{6}{|l|}{ Asset quality and composition } \\
\hline Nonperforming loans( NPLs) to total loans $3 /$ & 11.4 & 11.3 & 8.7 & 6.4 & 6.2 \\
\hline NPLs net of provisions to capital & 52.6 & 43.0 & 37.4 & 13.7 & 11.5 \\
\hline Restructured loans to regulatory capital & 41.8 & 47.2 & 20.5 & 6.1 & 4.0 \\
\hline Provisions to total loans & 3.4 & 4.0 & 3.2 & 3.7 & 3.5 \\
\hline Provisions to NPLs & 27.2 & 38.7 & 38.2 & 64.6 & 66.6 \\
\hline \multicolumn{6}{|l|}{ Sectoral distribution of loans to total loans: } \\
\hline Commerce & 19.2 & 17.7 & 15.8 & 16.0 & 16.9 \\
\hline Construction and real estate & 15.5 & 12.9 & 18.7 & 19.1 & 20.3 \\
\hline Agriculture and related sectors & 13.8 & 11.2 & 7.8 & 7.8 & 7.1 \\
\hline Manufacturing & 16.9 & 17.5 & 19.4 & 20.3 & 18.4 \\
\hline Consumption & 10.0 & 13.8 & 13.0 & 13.4 & 13.3 \\
\hline Other & 24.6 & 26.9 & 25.3 & 23.4 & 24.0 \\
\hline \multicolumn{6}{|l|}{ Profitability } \\
\hline Return on assets (ROA) 4/ & 0.9 & 0.8 & 1.2 & 1.2 & 1.5 \\
\hline Return on equity (ROE) & 8.4 & 8.2 & 11.8 & 14.9 & 17.6 \\
\hline Interest margin to total income & 39.4 & 41.5 & 45.0 & 44.4 & 47.2 \\
\hline Personnel expenses to administrative expenses & 40.8 & 38.0 & 36.7 & 35.4 & 37.2 \\
\hline \multicolumn{6}{|l|}{ Liquidity } \\
\hline Liquid assets to total assets & 26.6 & 30.1 & 24.9 & 28.1 & 30.2 \\
\hline Liquid assets to total short-term liabilities & 58.2 & 64.1 & 53.2 & 60.7 & 63.7 \\
\hline \multicolumn{6}{|l|}{ Dollarization } \\
\hline Foreign currency in percent of total deposits & 32.8 & 34.2 & 34.5 & 36.0 & 35.1 \\
\hline Foreign currency credit in percent of total credit & 25.4 & 26.2 & 28.7 & 33.8 & 34.0 \\
\hline
\end{tabular}

Sources: National Commission of Banking and Insurance; and Fund staff estimates.

1/ Preliminary.

2/ Includes contingent assets.

3/ NPLs exclude restructured loans, mostly to the agricultural sector.

4/ Assets include off-balance sheet items. 
Table 9. Honduras: Balance of Payments

(In millions of U.S. dollars; unless otherwise indicated)

\begin{tabular}{|c|c|c|c|c|c|c|c|c|}
\hline & \multirow[b]{2}{*}{2000} & \multirow[b]{2}{*}{2001} & \multirow[b]{2}{*}{2002} & \multirow[b]{2}{*}{2003} & \multirow{2}{*}{$\begin{array}{l}\text { Prel. } \\
2004\end{array}$} & \multicolumn{2}{|c|}{2005} & \multirow{2}{*}{$\begin{array}{l}\text { Proj. } \\
2006\end{array}$} \\
\hline & & & & & & 2nd Rev. & Proj. & \\
\hline Current account & -226 & -260 & -205 & -293 & -352 & -199 & -172 & -258 \\
\hline Trade balance & $-1,233$ & $-1,395$ & $-1,442$ & $-1,680$ & $-2,094$ & $-2,246$ & $-2,547$ & $-3,060$ \\
\hline Exports & 1,437 & 1,375 & 1,364 & 1,385 & 1,598 & 1,644 & 1,759 & 1,839 \\
\hline Imports $1 /$ & $-2,670$ & $-2,769$ & $-2,806$ & $-3,066$ & $-3,692$ & $-3,889$ & $-4,305$ & $-4,900$ \\
\hline Services & 394 & 339 & 432 & 536 & 632 & 704 & 699 & 763 \\
\hline Income (net) & -139 & -176 & -200 & -260 & -282 & -305 & -280 & -284 \\
\hline \multicolumn{9}{|l|}{ Of which } \\
\hline Interest payments & -187 & -157 & -144 & -131 & -119 & -118 & -117 & -96 \\
\hline Current transfers (net) & 753 & 972 & 1,004 & 1,112 & 1,393 & 1,647 & 1,956 & 2,323 \\
\hline Public sector 2/ & 306 & 409 & 270 & 229 & 223 & 281 & 275 & 327 \\
\hline Private sector & 447 & 563 & 734 & 883 & 1,170 & 1,367 & 1,681 & 1,996 \\
\hline Capital account & -22 & 123 & 154 & 74 & 752 & 290 & 339 & 435 \\
\hline Foreign direct investment (net) & 282 & 193 & 176 & 247 & 325 & 190 & 252 & 290 \\
\hline Portfolio investments (net) & -61 & -4 & -4 & -4 & -4 & -5 & -5 & -5 \\
\hline Public sector loans (net) & -13 & 107 & -29 & 6 & 176 & 103 & 104 & 188 \\
\hline Disbursements 3/ & 169 & 271 & 163 & 221 & 390 & 296 & 306 & 292 \\
\hline Amortization 3/ & -182 & -165 & -192 & -215 & -214 & -194 & -202 & -104 \\
\hline Other medium- and long-term loans (net) & -24 & -93 & -20 & -106 & 217 & -3 & 4 & -5 \\
\hline Other short-term capital (net) & -206 & -80 & 31 & -69 & 38 & 5 & -17 & -34 \\
\hline Errors and omissions & 101 & 125 & 70 & 9 & -38 & 0 & 0 & 0 \\
\hline Overall balance & 33 & 82 & 129 & -77 & 362 & 91 & 167 & 177 \\
\hline Net international reserves (- increase) & -20 & -80 & -129 & 77 & -496 & -210 & -282 & -177 \\
\hline Of which: IMF (net) & 4 & 7 & -27 & -24 & 24 & 3 & -3 & 3 \\
\hline Exceptional financing 4/ & -13 & -2 & 0 & 0 & 134 & 119 & 114 & 0 \\
\hline \multicolumn{9}{|l|}{ Memorandum items: } \\
\hline Terms of trade (percent change) & -7.4 & -7.8 & -7.6 & -5.6 & 2.3 & -0.3 & 1.1 & -2.8 \\
\hline Exports of goods and services (percent change) & 11.5 & -2.7 & 3.5 & 7.4 & 14.3 & 6.7 & 9.5 & 8.0 \\
\hline Of which: goods only & 18.0 & -4.3 & -0.8 & 1.5 & 15.3 & 4.0 & 10.1 & 4.6 \\
\hline Imports of goods and services (percent change) & 9.3 & 4.4 & 1.1 & 9.1 & 18.3 & 5.6 & 14.9 & 13.7 \\
\hline \multirow{2}{*}{\multicolumn{9}{|c|}{$\begin{array}{l}\text { Of which: goods only } \\
\text { Current account (in percent of GDP) }\end{array}$}} \\
\hline & & & & & & & & \\
\hline Including official transfers & -3.8 & -4.1 & -3.1 & -4.2 & -4.7 & -2.5 & -2.1 & -2.9 \\
\hline Excluding official transfers & -8.8 & -10.4 & -7.2 & -7.5 & -7.7 & -6.0 & -5.5 & -6.5 \\
\hline Overall balance (in percent of GDP) & 0.5 & 1.3 & 2.0 & -1.1 & 4.9 & 0.7 & 2.1 & 2.0 \\
\hline Gross reserves (end of period) & 1,285 & 1,414 & 1,523 & 1,430 & 1,936 & 2,121 & 2,218 & 2,395 \\
\hline $\begin{array}{l}\text { In months of next year imports of nonmaquila goods } \\
\text { and nonfactor services }\end{array}$ & 4.4 & 4.9 & 5.2 & 4.5 & 4.5 & 4.9 & 4.6 & 4.8 \\
\hline In percent of short-term external debt $5 /$ & 245.0 & 280.1 & 261.9 & 323.0 & 293.7 & 446.9 & 373.4 & 425.6 \\
\hline Outstanding external debt $6 /$ & 4,404 & 4,526 & 4,657 & 4,845 & 5,082 & 4,152 & 4,154 & 4,326 \\
\hline Debt to GDP ratio (in percent) & 73.1 & 70.7 & 70.8 & 69.8 & 68.2 & 51.6 & 50.9 & 48.4 \\
\hline Public sector debt service paid to exports (in percent) 6/ & 8.3 & 6.3 & 7.8 & 8.2 & 6.1 & 4.5 & 4.4 & 4.0 \\
\hline Nominal GDP & 6,025 & 6,400 & 6,580 & 6,945 & 7,455 & 8,045 & 8,157 & 8,942 \\
\hline
\end{tabular}

Sources: Central Bank of Honduras; and Fund staff estimates and projections.

1/ Includes special imports for investment projects of US\$400 million in 2004 and US\$100 million in 2005

2 / Includes HIPC grants from the World Bank, IDB, and the Fund.

3/ Net of debt relief operation granted by the Central American Bank for Economic Integration (CABEI) in 2000.

4/ Assumes all bilateral Paris Club agreements will be signed by end-2005.

5/ External debt due within a year.

6/ Medium- and long-term public and publicly guaranteed external debt, after HIPC and beyond HIPC debt relief. 
Table 10. Honduras: Summary of Macroframework

\begin{tabular}{|c|c|c|c|c|c|c|c|c|}
\hline & \multirow{2}{*}{$\begin{array}{l}\text { Prel. } \\
2004 \\
\end{array}$} & \multicolumn{2}{|c|}{2005} & \multicolumn{2}{|c|}{2006} & \multicolumn{3}{|c|}{ Projected } \\
\hline & & Prog. & Rev.Prog & Prog. & Rev.Prog & 2007 & 2008 & 2009 \\
\hline \multicolumn{9}{|c|}{ (Annual percentage change) } \\
\hline \multicolumn{9}{|l|}{ National income and prices } \\
\hline GDP at constant prices & 4.6 & 4.2 & 4.2 & 4.5 & 4.3 & 4.5 & 4.5 & 4.5 \\
\hline \multicolumn{9}{|l|}{ Of which } \\
\hline Consumption & 1.4 & 4.2 & 11.8 & 5.0 & 6.8 & 5.3 & 4.6 & 4.5 \\
\hline Investment & 22.4 & -0.4 & -6.4 & 9.3 & 1.1 & 7.1 & 8.5 & 7.0 \\
\hline Exports & 13.7 & 6.1 & 8.6 & 6.4 & 6.3 & 5.8 & 6.0 & 6.0 \\
\hline Imports & 15.1 & 2.7 & 17.0 & 10.3 & 15.6 & 9.0 & 8.3 & 8.1 \\
\hline Consumer prices (end of period) & 9.2 & 6.9 & 9.0 & 5.0 & 6.7 & 5.0 & 4.0 & 3.0 \\
\hline GDP per capita (in U.S. dollars) & 1,039 & 1,106 & 1,128 & 1,218 & 1,218 & 1,278 & 1,329 & 1,381 \\
\hline Poverty rate $1 /$ & 64.2 & 63.1 & 63.1 & 61.9 & 61.9 & 60.2 & 58.6 & 57.0 \\
\hline \multicolumn{9}{|c|}{ (In percent of GDP, unless otherwise stated) } \\
\hline \multicolumn{9}{|l|}{ Combined public sector } \\
\hline Savings & 3.3 & 4.4 & 4.0 & 5.5 & 4.5 & 4.5 & 4.5 & 4.5 \\
\hline Antipoverty spending & 8.4 & 8.7 & 8.7 & 9.4 & 9.4 & 9.4 & 9.4 & 9.4 \\
\hline Overall balance & -3.0 & -2.5 & -2.5 & -1.7 & -1.7 & -1.7 & -1.6 & -1.6 \\
\hline \multicolumn{9}{|l|}{ Of which } \\
\hline Central government balance & -3.5 & -3.0 & -3.2 & -2.5 & -2.5 & -2.5 & -2.5 & -2.5 \\
\hline General government balance & -2.1 & -0.9 & -1.8 & -0.4 & -0.9 & -0.9 & -0.9 & -0.9 \\
\hline Public sector debt & 73.3 & 56.1 & 55.4 & 54.0 & 52.5 & 51.7 & 49.6 & 49.1 \\
\hline \multicolumn{9}{|l|}{ Savings and investment } \\
\hline Fixed capital formation & 27.9 & 24.5 & 23.7 & 24.9 & 24.9 & 25.0 & 25.6 & 25.0 \\
\hline Private sector & 22.0 & 17.8 & 17.2 & 19.2 & 18.4 & 18.3 & 18.9 & 18.3 \\
\hline Public sector & 5.9 & 6.7 & 6.6 & 6.0 & 6.6 & 6.7 & 6.7 & 6.7 \\
\hline Gross domestic saving & 23.2 & 22.0 & 21.6 & 22.5 & 22.0 & 21.7 & 22.3 & 22.5 \\
\hline Private sector & 19.1 & 17.4 & 18.6 & 18.0 & 19.0 & 16 & 16.6 & 16.6 \\
\hline Public sector & 4.1 & 4.6 & 3.0 & 4.5 & 3.0 & 5.7 & 5.7 & 5.7 \\
\hline External current account balance & -4.7 & -2.5 & -2.1 & -2.4 & -2.9 & -3.3 & -3.3 & -2.5 \\
\hline \multicolumn{9}{|l|}{ Gross international reserves } \\
\hline (in months of imports) $2 /$ & 4.5 & 4.9 & 4.6 & 5.2 & 4.8 & 5.4 & 5.5 & 5.6 \\
\hline \multicolumn{9}{|l|}{ External public debt $3 /$} \\
\hline NPV of public sector debt after HIPC relief 4/ & 51.7 & 33.6 & 33.6 & 32.7 & 32.7 & 32.3 & 31.5 & 31.0 \\
\hline (in percent of current government revenue) & 262.6 & 173.0 & 172.1 & 170.2 & 170.2 & 168.0 & 163.9 & 161.5 \\
\hline (in percent of exports) $5 /$ & 139.6 & 89.5 & 89.3 & 86.3 & 86.2 & 85.4 & 83.0 & 81.7 \\
\hline Public sector external debt after HIPC relief 4/ & 68.2 & 51.6 & 50.9 & 49.8 & 48.4 & 47.8 & 46.1 & 45.1 \\
\hline
\end{tabular}

Sources: Central Bank of Honduras; Ministry of Finance; and Fund staff estimates and projections.

1/ Taken from I-PRSP based on Honduras Multipurpose household survey. Projections based on income poverty elasticity of 0.6 percent.

2/ Refers to next year's imports of non-maquila goods and services.

3/ Comprises medium- and long-term public and publicly guaranteed external debt.

4/ Assumes HIPC completion point in March 2005 and beyond HIPC relief from Paris Club creditors.

5/ Three-year backward-looking average of exports of goods and services. 
Table 11. Honduras: External Financing Requirements and Sources

(In millions of U.S. dollars)

\begin{tabular}{|c|c|c|c|c|c|c|c|}
\hline & \multirow[b]{2}{*}{2000} & \multirow[b]{2}{*}{2001} & \multirow[b]{2}{*}{2002} & \multirow[b]{2}{*}{2003} & \multirow{2}{*}{$\begin{array}{c}\text { Prel. } \\
2004\end{array}$} & \multicolumn{2}{|c|}{ Rev. Prog. } \\
\hline & & & & & & 2005 & 2006 \\
\hline 1. Gross financing requirements & $-1,095$ & $-1,217$ & -913 & -904 & $-1,179$ & $-1,167$ & $-1,101$ \\
\hline External current account deficit (exc. official transfers) & -532 & -669 & -476 & -522 & -574 & -446 & -584 \\
\hline Debt amortization & -503 & -439 & -291 & -435 & -263 & -378 & -298 \\
\hline Medium- and long-term debt & -296 & -359 & -322 & -366 & -301 & -362 & -264 \\
\hline Public sector & -182 & -165 & -192 & -215 & -214 & -202 & -104 \\
\hline Commercial banks & -89 & -98 & -84 & -57 & -48 & -92 & -100 \\
\hline Corporate private sector & -26 & -96 & -46 & -94 & -40 & -67 & -60 \\
\hline Short-term debt (net) $1 /$ & -206 & -80 & 31 & -69 & 38 & -17 & -34 \\
\hline Repayment of arrears & 0 & 0 & 0 & 0 & 212 & 0 & 0 \\
\hline Gross reserves accumulation & -56 & -101 & -107 & 94 & -538 & -315 & -191 \\
\hline IMF repurchases and repayments & -5 & -9 & -40 & -41 & -15 & -27 & -27 \\
\hline 2. Available financing & 1,095 & 1,217 & 913 & 904 & 1,179 & 1,167 & 1,101 \\
\hline Foreign direct investment (net) & 282 & 193 & 176 & 247 & 325 & 252 & 290 \\
\hline Debt financing from private creditors & 91 & 101 & 110 & 45 & 304 & 164 & 155 \\
\hline Medium- and long-term financing & 91 & 101 & 110 & 45 & 304 & 164 & 155 \\
\hline Public sector & 0 & 0 & 0 & 0 & 0 & 0 & 0 \\
\hline Commercial banks & 48 & 52 & 70 & 48 & 128 & 87 & 55 \\
\hline Corporate private sector & 43 & 49 & 40 & -2 & 177 & 76 & 100 \\
\hline Official creditors $2 /$ & 475 & 679 & 429 & 450 & 607 & 567 & 610 \\
\hline Loan disbursements & 169 & 271 & 163 & 221 & 390 & 306 & 292 \\
\hline Of which: program loans & & & & & 0 & 0 & 0 \\
\hline Grants & 306 & 408 & 266 & 229 & 217 & 261 & 319 \\
\hline IMF 3/ & 21 & 22 & 5 & 0 & 36 & 45 & 39 \\
\hline Accumulation of arrears (exceptional) 4/ & 0 & 0 & 0 & 132 & 17 & 0 & 0 \\
\hline Debt rescheduling (already agreed) & $\ldots$ & $\ldots$ & $\ldots$ & $\ldots$ & 328 & 114 & 0 \\
\hline Of which: arrears & $\ldots$ & $\ldots$ & $\ldots$ & $\ldots$ & -212 & $\ldots$ & $\ldots$ \\
\hline Other flows $5 /$ & 226 & 222 & 194 & 28 & -438 & 25 & 7 \\
\hline 3. Financing gap & $\mathbf{0}$ & $\mathbf{0}$ & $\mathbf{0}$ & $\mathbf{0}$ & $\mathbf{0}$ & $\mathbf{0}$ & $\mathbf{0}$ \\
\hline \multicolumn{8}{|l|}{ Of which: } \\
\hline Unidentified financing & $\ldots$ & $\ldots$ & $\ldots$ & $\ldots$ & $\ldots$ & 0 & 0 \\
\hline Possible debt rescheduling (including beyond HIPC) & $\ldots$ & $\ldots$ & $\ldots$ & $\ldots$ & $\ldots$ & -21 & 0 \\
\hline
\end{tabular}

Sources: Central Bank of Honduras; and Fund staff estimates and projections.

1/ Original maturity of less than 1 year. Stock at the end of the previous period.

2/ Excluding the IMF.

3/ Including IMF HIPC grants.

4/ The figure for 2004 consists of technical arrears with Paris Club creditors, pending finalization of bilateral agreemen following the April 2004 Paris Club rescheduling.

5/ Includes all other net financial flows, and errors and omissions. 
Table 12. Honduras: Indicators of Fund Credit

(In units indicated)

\begin{tabular}{|c|c|c|c|c|c|c|c|c|c|}
\hline & \multirow[b]{2}{*}{2001} & \multirow[b]{2}{*}{2002} & \multirow[b]{2}{*}{2003} & \multirow[b]{2}{*}{2004} & \multicolumn{5}{|c|}{ Projections } \\
\hline & & & & & 2005 & 2006 & 2007 & 2008 & 2009 \\
\hline \multicolumn{10}{|l|}{$\begin{array}{l}\text { Stock of existing } \\
\text { and prospective Fund credit } 1 /\end{array}$} \\
\hline In millions of SDRs & 175.1 & 144.6 & 115.4 & 125.7 & 127.8 & 129.7 & 118.3 & 96.6 & 79.9 \\
\hline In percent of quota & 135.2 & 111.7 & 89.1 & 97.1 & 98.7 & 100.2 & 91.3 & 74.6 & 61.7 \\
\hline In percent of exports of goods and services & 9.1 & 7.7 & 6.3 & 6.3 & 5.6 & 5.3 & 4.6 & 3.5 & 2.8 \\
\hline In percent of external debt & 4.9 & 4.2 & 3.5 & 3.8 & 4.6 & 4.5 & 3.9 & 3.1 & 2.5 \\
\hline In percent of gross reserves & 16.0 & 13.0 & 12.1 & 10.0 & 8.5 & 7.9 & 6.7 & 5.3 & 4.2 \\
\hline \multicolumn{10}{|l|}{$\begin{array}{l}\text { Obligations to the Fund from existing } \\
\text { and prospective Fund arrangements }\end{array}$} \\
\hline In millions of SDRs & 10.3 & 32.7 & 30.7 & 11.0 & 19.2 & 19.3 & 22.7 & 22.5 & 17.5 \\
\hline In percent of quota & 7.9 & 25.2 & 23.7 & 8.5 & 14.9 & 14.9 & 17.5 & 17.4 & 13.5 \\
\hline In percent of exports of goods and services & 0.5 & 1.7 & 1.7 & 0.5 & 0.8 & 0.8 & 0.9 & 0.8 & 0.6 \\
\hline In percent of external debt & 0.3 & 0.9 & 0.9 & 0.3 & 0.7 & 0.7 & 0.8 & 0.7 & 0.5 \\
\hline In percent of gross reserves & 0.9 & 2.9 & 3.2 & 0.9 & 1.3 & 1.2 & 1.3 & 1.2 & 0.9 \\
\hline
\end{tabular}

Sources: Central Bank of Honduras; and Fund staff estimates.

1/ End of period. 
Table 13. Honduras: Review and Phasing of Disbursements under the PRGF Arrangement, 2004-2007

\begin{tabular}{lccc}
\hline & \multicolumn{2}{c}{ Expected Disbursements } & \\
\cline { 2 - 3 } Date & $\begin{array}{c}\text { In millions } \\
\text { of SDRs }\end{array}$ & $\begin{array}{c}\text { In percent } \\
\text { of quota }\end{array}$ & Conditions to be Observed \\
\hline February 2004 & 10.171 & 7.85 & Board approval of PRGF Arrangement \\
September 2004 & 10.171 & 7.85 & First review; and end-June 2004 performance criteria \\
March 2005 & 10.171 & 7.85 & Second review; and end-December 2004 performance criteria \\
December 2005 & 10.171 & 7.85 & Third review; and end-June 2005 performance criteria \\
April 2006 & 10.171 & 7.85 & Fourth review; and end-December 2005 performance criteria \\
September 2006 & 10.171 & 7.85 & Fifth review; and end-June 2006 performance criteria \\
February 2007 & 10.174 & 7.86 & Sixth review; and end-December 2006 performance criteria \\
\hline
\end{tabular}

Source: Fund staff projections. 
HoNduras: Fund RELATIONS

(As of September 30, 2005)

I. Membership Status: Joined December 27, 1945; Article VIII

II. General Resources Account:

Quota

Fund holdings of currency

Million

Percent

Reserve Position

129.50

120.87

8.63

of Quota

100.00

93.34

6.66

III. SDR Department:

SDR Million

Percent of

Net cumulative allocation

19.06

Allocation

Holdings

0.11

100.00

0.55

IV. Outstanding Purchases and Loans:

SDR Million

PRGF Arrangement

126.25

Percent

of Quota

97.49

V. Latest Financial Arrangements:

\begin{tabular}{lllcr}
\hline Type & $\begin{array}{c}\text { Approval } \\
\text { Date }\end{array}$ & $\begin{array}{c}\text { Expiration } \\
\text { Date }\end{array}$ & $\begin{array}{c}\text { Amount Approved } \\
\text { (SDR Million) }\end{array}$ & $\begin{array}{c}\text { Amount Drawn } \\
\text { (SDR Million) }\end{array}$ \\
\hline PRGF & $02 / 27 / 2004$ & $02 / 26 / 2007$ & 71.20 & 30.51 \\
PRGF & $03 / 26 / 1999$ & $12 / 31 / 2002$ & 156.75 & 108.30 \\
PRGF & $07 / 24 / 1992$ & $07 / 24 / 1997$ & 47.46 & 33.90 \\
& & & & \\
\hline
\end{tabular}

VI. Projected Payments to Fund (without HIPC assistance) (SDR million; based on existing use of resources and present holdings of SDRs):

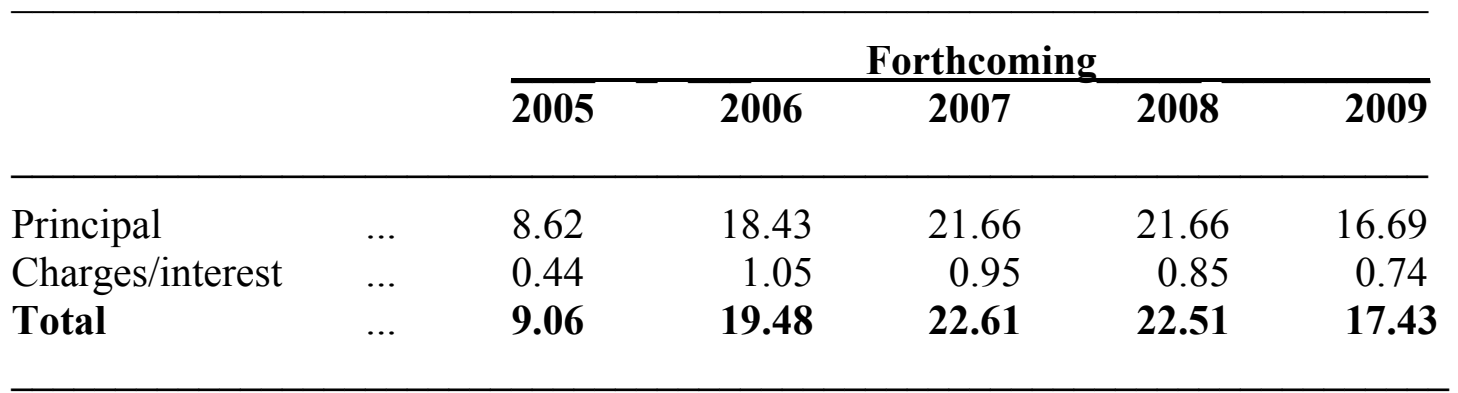


Projected Payments to Fund (with Board-approved HIPC assistance) (SDR million; based on existing use of resources and present holdings of SDRs):

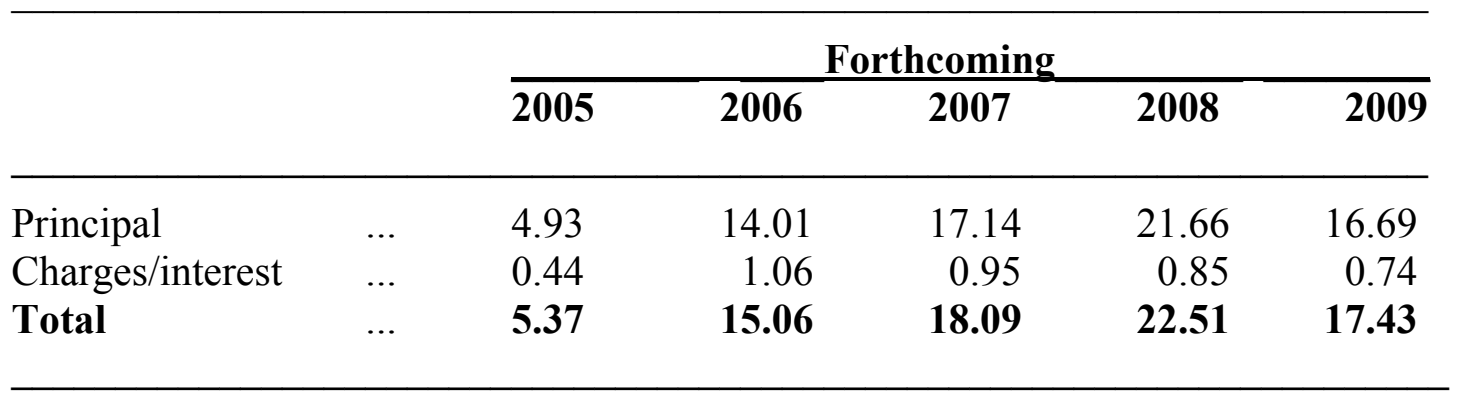

VII. Implementation of Enhanced HIPC Initiative:

\section{Commitment of HIPC assistance}

Decision point date

Assistance committed (NPV terms)

Total assistance (US\$ million)

Of which: Fund assistance (US\$ million)

Completion point date

\section{Delivery of Fund assistance (SDR million)}

Amount disbursed

Interim assistance

Completion point balance

Additional disbursement of interest income

Total disbursements
June 30, $2000^{1}$

End-1999

556.00

30.30

April 2005

22.66

8.80

13.86

3.70

26.36

VIII. Safeguards Assessments Policy:

A full safeguards assessment of the central bank with respect to the PRGF arrangement was completed on February 17, 2004. It found that progress has been made in strengthening the BCH's safeguards framework since a transitional assessment was conducted in 2001, but some weaknesses remained. The most important vulnerabilities relate to the non-publication of the audited financial statements and absence of a methodology to oversee the audit mechanisms and to follow-up on audit recommendations. The $\mathrm{BCH}$ has implemented most of the

\footnotetext{
${ }^{1}$ World Bank Board, July 6, 2000.
} 
safeguards recommendations, including publishing the 2002 and 2003 financial statements and establishing an audit committee.

\section{Exchange Arrangement:}

Honduras' de jure exchange arrangement is a crawling band, but the de facto exchange rate regime is a crawling peg. The exchange rate for the lempira is determined daily in foreign exchange auctions. Banks and exchange houses must sell to the central bank 100 percent of their daily net purchases of foreign exchange at the exchange rate established the previous day. Buyers of foreign exchange (banks, exchange houses, and private individuals) bid at a price that cannot differ by more than 7 percent from the base exchange rate, in either direction. The base exchange rate is adjusted every five auctions according to the anticipated inflation differential between Honduras and its major trading partners and on changes in the exchange rates of currencies of trading partners of Honduras with respect to the U.S. dollar. The official buying exchange rate on September 22, 2005 was L 18.88 per U.S. dollar.

Honduras has accepted the obligations under Article VIII, Section 2, 3, and 4 of the Articles of Agreement, and maintains a system that is free of restrictions on the making of payments and transfers for current international transactions.

\section{Article IV Consultation:}

The last Article IV consultation with Honduras was concluded on March 28, 2005. On the occasion, Directors considered the second review under the three-year PRGF arrangement, and the completion point document, under the Enhanced Initiative for Heavily Indebted Countries. It is proposed that the next Article IV consultation with Honduras be held in accordance with the July 15, 2002 decision on consultation cycles.

\section{FSAP Participation and ROSCs:}

Fiscal ROSC conducted on February 26-March 2, 2001 (IMF Country Report No. 02/16) and updated (IMF Country Report No. 05/256).

FSAP conducted on October 14-19, 2002 and January 20-February 4, 2003. Data ROSC data conducted on July 8-24, 2003 (IMF Country Report No. 05/230). 
XII. Technical Assistance:

Dept.

FAD Impact of CAFTA on fiscal accounts

Public expenditure management, tracking of poverty reducing spending, and fiscal transparency.

Resident expert in tax administration.

INS Course on trade and exchange rate policies.

MFD Follow up on modernization of monetary operations Follow up on modernization of monetary operations Flexibilization of exchange rate system Modernization of monetary operations Banking crisis management framework. Peripatetic short-term advisor for bank supervision, onsite inspection, and the bank restructuring framework.

STA National income accounts

Government finance statistics

Implementation of BPM5

Follow-up on money and banking statistics.
Time

May 2004

Sep.-Oct. 2003

May 2001-June 2003

February 2002

May 2005

December 2004

June 2004

April 2004

August 2003

Jun. 1998-Dec. 2002

January 2005

July-Aug. 2004

May 2004

September 2003

\section{Resident Representative:}

Mr. Hunter Monroe assumed duty in July 2005. 


\section{HONDURAS-RELATIONS WITH THE WORLD BANK}

(As of October 19, 2005)

\section{Partnership in Honduras' Development Strategy}

1. Honduras' Poverty Reduction Strategy Paper (PRSP), which was completed in October 2001 and endorsed by the Boards of the World Bank and IMF, has placed poverty reduction squarely at the center of the government's development agenda. The main objective of the strategy, which analyzes the causes of poverty and encompasses investment programs and reforms in a broad range of sectors, is to reduce poverty by 24 percentage points over the period 2001-15. The strategy itself is structured around six pillars as follows: (i) accelerating equitable and sustainable growth to levels consistent with the income poverty reduction targets; (ii) reducing rural poverty; (iii) reducing urban poverty; (iv) enhancing investment in human capital; (v) strengthening social protection for specific vulnerable groups; and (vi) ensuring the sustainability of the strategy through governance and institutional reforms and enhanced environmental sustainability. The Second Annual PRSP Progress Report, approved in March, 2005 by the Board of the World Bank, maintains the same long-term vision and targets of the PRSP.

2. The Government of Honduras reached Completion Point under the HIPC initiative in March 2005. Implementation of the PRSP program will require active participation of the government, civil society and donors. To this end the government has established a Consultative Council for the PRSP which meets regularly and reviews progress in the implementation of the program. The government published its first 2005 quarterly PRSP Implementation Report in June 2005 and the second is due in October.

3. The Fund and World Bank will continue to cooperate closely, within their respective mandates, in assisting the government to implement its poverty reduction and economic growth strategy and the related reform agenda. The Fund will continue to lead the policy dialogue on macroeconomic issues (i.e., fiscal, monetary, and exchange rate policy), while the World Bank leads the policy dialogue on poverty reduction, governance, public sector management, and sectoral structural reforms (in areas including the social sectors, land regularization, environment, competitiveness, and judicial reform).

\section{Bank Group Assistance Strategy}

4. The World Bank completed the last Country Assistance Strategy (CAS) in May 2003, which is fully aligned with the six pillars of the Honduras' Poverty Reduction Strategy. The core goal of the CAS is to support Honduran efforts to shift to a sustainable and inclusive higher-growth trajectory as a principal means of reducing poverty and inequality. Within this broad objective, the main emphasis of the Bank's lending and knowledge services to Honduras are threefold: (i) to increase productive economic opportunities by helping to remove structural and institutional barriers to economic growth and broad-based participation in growth; (ii) to invest in human capital and the protection of vulnerable groups; and (iii) to support the transparent and responsive functioning of the public sector. In terms of lending, the CAS program comprises 14 operations over a 4-year period (FY03-06), amounting to 
about US\$296 million, of which, about US\$83.8 million is in the form of quick-disbursing budgetary support comprising a PRSC (US\$58.8 million) and Financial Sector Development Credit (US\$25 million).

5. As of October 19, 2005, the IDA active portfolio in Honduras consists of 21 projects for a total commitment of US\$482 million, of which US\$269 million remain to be disbursed (Honduras was declared IDA-only in September 1991). Lending for rural poverty and human resource development includes five credits: Fifth Social Investment Fund Credit (US\$60 million), a Learning and Science Promotion Credit-PROFUTURO supplementary credit (US\$4 million), a Community Based Education Credit (US\$42 million), a Health System Reform Credit (US\$27 million), and targeted support to indigenous groups through the Nuestras Raices Project (US\$15 million). Lending for transport and infrastructure includes a Road Reconstruction and Improvement Credit (US\$67 million); for natural resource management and environment consists of an Access to Land Pilot Credit (US\$8 million), a Sustainable Costal Tourism Credit (US\$5 million), a Regional Development in the Copan Valley Credit (US\$12 million), a Land Administration Program (US\$25 million), and a Forest and Rural Productivity (US\$20 million); for public sector and economic management consists of an Economic and Financial Management Technical Assistance Credit (US\$19 million), a Financial Sector Technical Assistance Credit (US\$10 million), a Poverty Reduction Strategy Technical Assistance Credit (US\$8 million); for disaster preparedness consists of an Emergency Disaster Management Credit (US\$11 million); and for investment climate improvement and private sector participation consists of a Trade Facilitation and Productivity Enhancement Credit (US\$28 million).

6. In addition to the preceding operations, IDA's Board of Executive Directors approved four new credits in July 2005, but have not yet been declared effective: a Nutrition and Social Protection (US\$20 million) that trains youth for opportunities in the local job market; a Rural Infrastructure Project (US\$47 million) to develop decentralized infrastructure through projects in electricity, water and sanitation and roads selected by communities; the Barrio Ciudad Project (US\$15 million) for urban upgrading through the strengthening of the municipal credit market; and a Judicial Branch Modernization (US\$15 million) to increase access to justice for the poor. In addition, a fast-disbursing First Programmatic Financial Sector Development Policy Credit (US\$25 million) was also approved in February 2005.

7. With regard to economic and sector work, the current CAS includes two types of activities. The first set includes core diagnostic analyses, which are country-specific and address important cross-cutting issues, including deepened understanding of poverty, growth, public expenditures and fiduciary issues. This includes the Development Policy Review, Country Financial Accountability Assessment and Country Procurement Assessment Report that were completed in FY04, as well as a Poverty Assessment (scheduled for December 2005) and a Public Expenditure Review which will start in FY06. The second group of activities, are Central America-wide or sub-regional in scope, focusing on topics and themes relevant to several countries but including sufficient country-specificity to further Honduras' development agenda and support the design of lending operations. This includes sector studies on the coffee shock, rural growth, CAFTA, HIV/AIDS, Investment Climate Assessment, decentralization and disaster mitigation. 
8. The Bank intends to submit the next CAS covering the period 2007-2010 to the Board in early fiscal year 2007.

\section{IMF-World Bank Collaboration in Specific Areas}

9. Fund and Bank staff have maintained a close working relationship, especially with respect to (i) the PRSP, its subsequent updates and joint assessments; (ii) the HIPC Initiative, (iii) financial sector reform; and (iv) civil service reform. The World Bank and IMF resident representatives routinely consult and coordinate with each other on major public policy matters, and Bank staff have participated in the Fund's PRGF missions.

- $\quad$ Poverty Reduction Strategy Paper Progress Reports (PRSP). The Fund and Bank supported the government in the preparation of the PRSP, completed in August 2001, and continued to follow its implementation. The first Progress Report was completed in December 2003. The second PRSP Progress Report was approved on March 2005. The Bank and Fund collaborated in the production of Joint Staff Assessment, which accompanied the presentation of the PRSP and PRSP Progress Reports to their respective Boards.

- $\quad$ HIPC Initiative. The Fund and Bank jointly tracked the status of floating completion point conditions established under the Enhanced HIPC Initiative. Further progress in structural and social reforms continue to be monitored, including measures in the areas of governance and transparency, social security system reform, provision of basic health services for the poor, quality of education, safety nets and financial system reform.

- $\quad$ Financial Sector. The Fund and the Bank co-managed the preparation of the 2003 Honduras Financial Sector Assessment Program (FSAP). Based on the FSAP, the government embarked on a comprehensive financial system reform that aims at strengthening the regulatory framework and ongoing supervision, enhancing the efficiency of the financial safety net, and improving mechanisms for antimoney laundering and financing of terrorism. The Fund and the Bank continue to assist the government on these issues through a comprehensive technical assistance program.

- Civil Service Reform. The Fund and Bank have been supporting civil service reforms that aim to create a better trained, efficient and professional civil service, and to limit the unsustainable growth in the public sector wage bill observed over the last decade. 
Honduras: Financial Relations with the World Bank Group

(In millions of U.S. dollars)

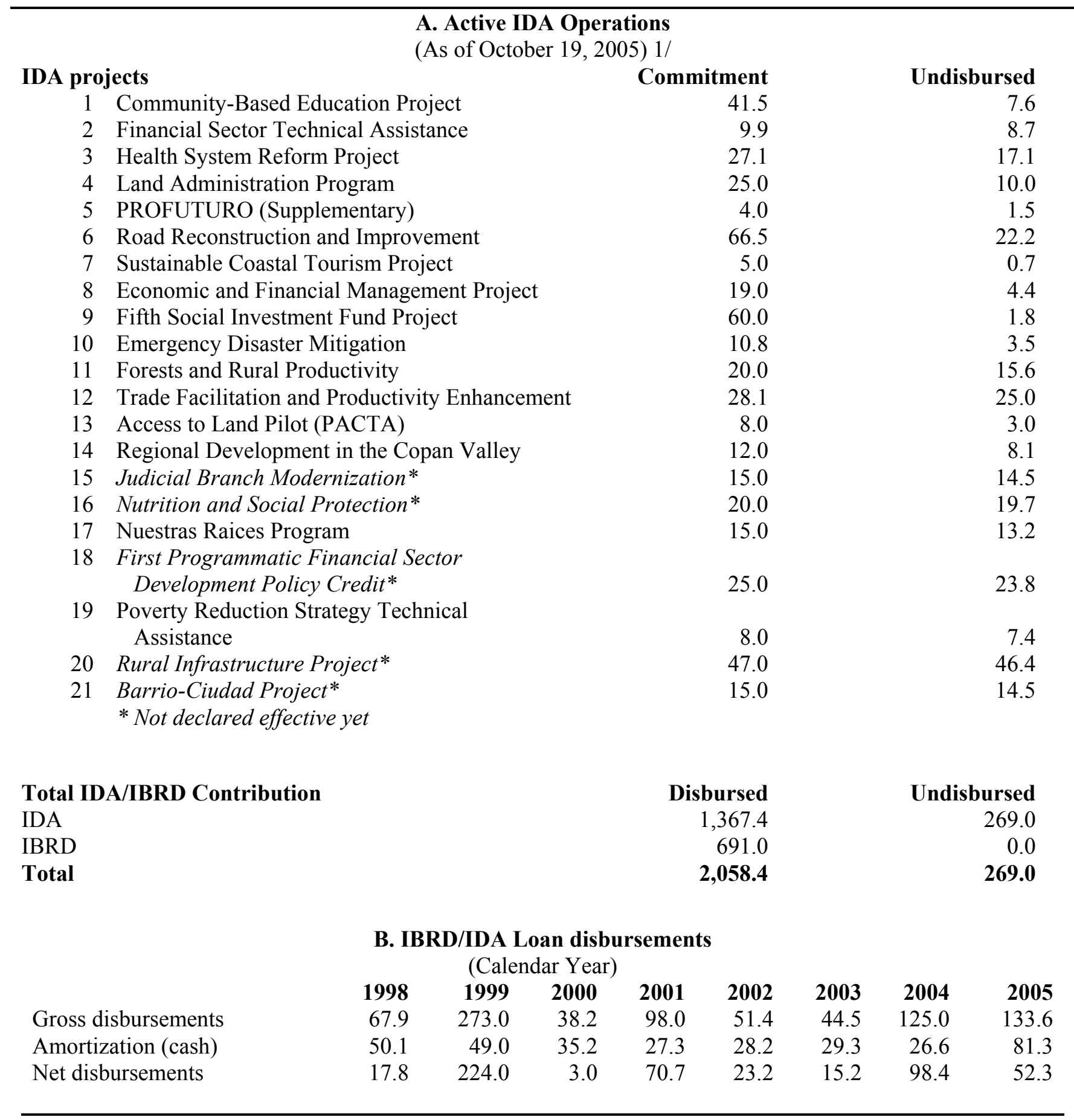

Source: World Bank estimates.

$1 /$ Net of cancellations. 


\title{
HONDURAS: RELATIONS WITH THE INTER-AMERICAN DEVELOPMENT BANK
}

\author{
(In millions of U.S. dollars)
}

Loans programmed for 2004-05

Financial sector program

Poverty Reduction Sector Program

Improvement of the PPP Atlantic Corridor

(Sections of the CA-5 Norte Highway)

Middle Education and Labor Program

Strengthening of Fiscal Management

Municipal Development Program Tegucigalpa II

Social Protection Program

PPP support to rural electrification and to the energy sector

Improvement of Health Conditions in Honduras

National Sustainable Tourism Program

Approved total

Fiscal reform

Comprehensive Development Autochthonous People

Expected approval total

Total
Status

Approved
Approved
Approved
Approved
Approved
Approved
Approved
Approved
Approved
Approved

Approved
Approved
Approved
Approved
Approved
Approved
Approved
Approved
Approved
Approved

Approved
Approved
Approved
Approved
Approved
Approved
Approved
Approved
Approved
Approved

Approved
Approved
Approved
Approved
Approved
Approved
Approved
Approved
Approved
Approved

Approved
Approved
Approved
Approved
Approved
Approved
Approved
Approved
Approved
Approved

Approved
Approved
Approved
Approved
Approved
Approved
Approved
Approved
Approved
Approved

Approved
Approved
Approved
Approved
Approved
Approved
Approved
Approved
Approved
Approved

Approved
Approved
Approved
Approved
Approved
Approved
Approved
Approved
Approved
Approved

Approved
Approved
Approved
Approved
Approved
Approved
Approved
Approved
Approved
Approved

Approved
Approved
Approved
Approved
Approved
Approved
Approved
Approved
Approved
Approved

Policy-based loan

25.0

30.0

50.0

30.6

15.0

22.5

20.0

35.0

16.6

35.0

279.7

30.0

11.1

320.8

320.8

A. Operations (as of October 24, 2005)

Approved

Credit

Agriculture

Urban Development

Education

Energy

Social Investment

Private Sector

Environment

State Reform and Modernization

Health

Sanitation

Transportation

Tourism

Total

Disbursements

Amortization

Net flow of resources

Commitments made

Undisbursed commitments
12.0

45.0

104.9

62.1

75.0

159.9

10.0

57.8

91.2

52.6

26.0

84.4

35.0

815.8

\section{B. Net Flow of Resources}

\section{Disbursed}

9.1

40.0

60.4

22.7

2.0

67.9

2.7

11.1

29.7

1.9

2.8

32.1

0.0

312.2
Undisbursed

2.9

5.0

44.5

39.4

73.0

91.9

7.3

46.7

61.5

20.7

23.2

52.4

35.0

503.6

$\begin{array}{rrrrrrc}\mathbf{1 9 9 9} & \mathbf{2 0 0 0} & \mathbf{2 0 0 1} & \mathbf{2 0 0 2} & \mathbf{2 0 0 3} & \mathbf{2 0 0 4} & \mathbf{2 0 0 5} \mathbf{1} / \\ 76.4 & 68.2 & 103.8 & 47.7 & 89.7 & 138.3 & 106.0 \\ 24.9 & 33.2 & 24.4 & 28.5 & 44.8 & 44.0 & 50.3 \\ 51.5 & 35.0 & 79.4 & 19.2 & 44.9 & 94.3 & 55.7 \\ 85.2 & 152.4 & 68.1 & 81.8 & 82.5 & 228.1 & 81.6 \\ 315.9 & 387.8 & 353.9 & 389.2 & 380.5 & 480.6 & 456.2\end{array}$

1/ Projections. 


\section{HONDURAS: STATISTICAL ISSUES}

\section{Introduction}

1. Honduras' data on the banking system, the public finances, trade, and external debt broadly satisfy the minimum criteria required for surveillance and program monitoring purposes. However, incomplete coverage of institutions and reporting lags inhibit a full and timely assessment of financial sector developments, and a consistent and reliable method is still needed for deriving quarterly estimates of national accounts.

2. The Honduran authorities participated in a ROSC data module (July 2003), signaling their interest in participating in the General Data Dissemination System (GDDS). Honduras joined the GDDS in September 2005. It is hoped that participation will spur strengthening of the country's statistical system, and provide a framework for channeling technical assistance resources in an optimally.

\section{Real sector}

3. Substantial progress has been made in preparation to migrate to the System of National Accounts 1993 (1993 SNA). An annual series has been prepared for the period 2000-02 based on the new methodology and with 2000 as the new base year. Intensive work has continued to ensure the quality of the series, prepare estimates for 2003-04, and commence preparations to produce quarterly estimates fully consistent with the new annual series.

4. Preparation of the new series has been supported by greater use of surveys and other data. In particular, estimates for construction activity have been derived from a new quarterly survey initiated in early 2004 with assistance from the National Statistics Directorate of Colombia. Also, business tax returns are now being accessed to obtain data on business investment (fixed capital formation and changes in inventories). Estimates of informal sector activity have been prepared by extrapolating data from the survey of household income and expenditure of 1998-99. The business register (directory) of 2000-01, currently being updated with administrative information, is being used as a basis for sampling decisions. Estimates of GDP are now based on the application of the double deflation method.

5. The CPI weights were 20 years old before a new household expenditure survey was conducted during 1998-99. As a result of this project, the authorities revised the CPI basket and updated the weights. The price reference period of the new index is December 1999. The Central Bank of Honduras $(\mathrm{CBH})$ produced in parallel the old and new indices during the transition period. The new indices became official in April 2000.

6. The new indices reflect improved coverage and quality of the data sources. The main improvements in coverage refer to inclusion in the survey of (i) population at all levels of income; (ii) goods and services with a participation of over 0.02 percent of total expenditure from a universe of 2,480 items; (iii) the concept of generic groups for similar items to be incorporated in the calculation; (iv) the use of a geometric mean; and (v) all representative 
urban areas. There are no official wage indices for minimum wages and data on employment are limited to a single estimate per year.

\section{Monetary accounts}

7. An STA mission (July-August 2000) reviewed the $\mathrm{CBH}$ procedures for compiling the detailed (sectorized) balance sheet for the $\mathrm{CBH}$ and other depository corporations as well as the analytical surveys. The mission designed new forms for reporting data to STA for publication in IFS and to WHD for operational purposes. In addition, the mission made recommendations to improve the timeliness and quality of data reported monthly to STA. Accordingly, the authorities reported monetary data in the revised format for the period January 1996 to December 2001 while still compiling data according to the old methodology. However, the $\mathrm{CBH}$ discontinued the new submission shortly afterwards; since February 2002 it has been reporting data in the old format despite several requests to resume the reporting of data in the revised format.

8. Further technical assistance in MFS was provided to Honduras in September 2001 and August 2004. The 2004 mission detected major progress in the compilation of the accounts of the central bank, but found serious shortcomings in the sectorization of the institutional units in the accounts of the other depository corporations. The mission recommended the establishment of an integrated database to report monetary statistics to the Fund for operational and publication purposes.

\section{Balance of payments}

9. Balance of payments statistics are compiled in broad conformity with the fourth edition of the Balance of Payments Manual (BPM4). Considerable progress has been made, however, in preparations to adopt the $B P M 5$, with preliminary annual estimates already available for 1993-2003, although not yet published. No international investment position is compiled. Departures from the criterion of residency underlie the treatment of the maquila sector, and some financial sector transactions in foreign currency. Net exports of the maquila industry are recorded as net services rather than as exports and imports of goods for processing. Nonrecording of profits of foreign enterprises operating in the maquila industry likely understates the external current account deficit, while direct investment in this industry is excluded from the financial account. Source data on direct investment, several services, and certain foreign transactions of private enterprises are relatively weak. Most annual surveys have low response rates, and results are obtained with long delays.

10. An STA mission visited Tegucigalpa during May 2004 to assist the $\mathrm{CBH}$ in preparing a comprehensive work program to implement the recommendations on balance of payments statistics made by the July 2003 data ROSC mission. Those included (1) completing compilation in accordance with BPM5 and beginning disseminating such data and related metadata; (2) improving recording of foreign trade data for the maquila (goods for processing) sector; (3) improving quarterly balance of payments statistics using quarterly sample surveys of enterprises; (4) improving the survey design and the compilation process 
for direct investment and other financial transactions of the nonfinancial private sector; and (5) training $\mathrm{CBH}$ staff in methodology and BOP compilation practices.

11. A follow-up ROSC mission conducted in May 2005 found that substantial progress has been made in adhering to the guidelines of the BPM5. In addition, the mission found that new surveys, more exhaustive use of other data, and better techniques are expected to enhance the accuracy and reliability of balance of payments estimates. The number of staff members dedicated to compiling balance of payments data has increased and training is ongoing.

\section{Government finance}

12. The Ministry of Finance (MoF) disseminates government finance statistics (GFS) covering only the central administration. The MoF also compiles annual GFS for the nonfinancial public sector (NFPS) for internal use and for reporting to the Western Hemisphere Department (WHD). The CBH does report budgetary central government data, although with considerable delay, for publication in the International Financial Statistics (IFS). Neither the MoF nor the CBH has reported GFS data for the Government Finance Statistics Yearbook (GFSY) recently.

13. The fiscal ROSC mission in 2002 and the data ROSC mission in 2003 both found that fiscal data in Honduras have serious weaknesses. The GFS issues related to coverage and sectorization can be explained to some extent by the Public Administration Law, which excludes the judicial and legislative branches from the data coverage of the central administration. The fiscal data also present large discrepancies between the overall balance compiled by the MoF and the financing data compiled by the $\mathrm{CBH}$. Therefore, stronger collaboration is needed between the $\mathrm{MoF}$ and the central bank to derive accurate and timely estimates of external financing of the nonfinancial public sector. In general, these data are not fully aligned with international standards, and there is no plan to migrate to the Government Finance Statistics Manual 2001 (GFSM 2001). The July 28-August 14, 2004 GFS mission produced a plan of action to improve fiscal data and proposed the creation of a working group for GFS compilation to implement that plan. The mission also recommended that the envisaged Integrated System of Financial Management be made to support the compilation of GFS data and gradual migration to the GFSM 2001. 
Honduras: TABLE OF COMMON INDICATORS REQUIRED FOR SURVEILLANCE

\begin{tabular}{|c|c|c|c|c|c|c|c|}
\hline \multirow[b]{3}{*}{ Exchange Rates } & \multirow{3}{*}{$\begin{array}{c}\begin{array}{c}\text { Date of } \\
\text { latest } \\
\text { observation }\end{array} \\
10 / 27 / 05\end{array}$} & \multirow{3}{*}{$\begin{array}{l}\text { Date } \\
\text { received }\end{array}$} & \multirow{3}{*}{$\begin{array}{c}\text { Frequency } \\
\text { of } \\
\text { Data }^{6} \\
\text { D }\end{array}$} & \multirow{3}{*}{$\begin{array}{c}\text { Frequency } \\
\text { of } \\
\text { Reporting }^{6}\end{array}$} & \multirow{3}{*}{$\begin{array}{c}\text { Frequency } \\
\text { of } \\
\text { publication } \\
6 \\
\text { D }\end{array}$} & \multicolumn{2}{|c|}{ Memo Items: } \\
\hline & & & & & & $\begin{array}{l}\text { Data Quality - } \\
\text { Methodological } \\
\text { soundness }\end{array}$ & $\begin{array}{c}\text { Data Quality - Accuracy } \\
\text { and reliability }\end{array}$ \\
\hline & & & & & & & \\
\hline $\begin{array}{l}\text { International Reserve Assets and Reserve Liabilities } \\
\text { of the Monetary Authorities }{ }^{1}\end{array}$ & $10 / 27 / 05$ & $10 / 28 / 05$ & $\mathrm{D}$ & $\mathrm{D}$ & $\mathrm{D}$ & & \\
\hline Reserve/Base Money & $10 / 27 / 05$ & $10 / 28 / 05$ & $\mathrm{D}$ & $\mathrm{D}$ & M & $\mathrm{O}, \mathrm{O}, \mathrm{LNO}, \mathrm{LO}$ & $\mathrm{O}, \mathrm{O}, \mathrm{O}, \mathrm{O}, \mathrm{LO}$ \\
\hline Broad Money & $8 / 05$ & $10 / 05$ & M & M & M & & \\
\hline Central Bank Balance Sheet & $10 / 27 / 05$ & $10 / 28 / 05$ & $\mathrm{D}$ & $\mathrm{D}$ & M & & \\
\hline Consolidated Balance Sheet of the Banking System & $8 / 05$ & $10 / 05$ & M & M & M & & \\
\hline Interest Rates ${ }^{2}$ & $8 / 05$ & $10 / 05$ & $\mathrm{~W}$ & $\mathrm{~W}$ & $\mathrm{~W}$ & & \\
\hline Consumer Price Index & $9 / 05$ & $10 / 10 / 05$ & M & M & M & $\mathrm{O}, \mathrm{O}, \mathrm{O}, \mathrm{O}$ & $\mathrm{O}, \mathrm{LO}, \mathrm{O}, \mathrm{O}, \mathrm{O}$ \\
\hline $\begin{array}{l}\text { Revenue, Expenditure, Balance and Composition of } \\
\text { Financing }{ }^{3} \text { - General Government }{ }^{4}\end{array}$ & $6 / 05$ & $8 / 05$ & M & M & M & LO, LNO, LNO, LNO & LO, O, LO, O, NO \\
\hline $\begin{array}{l}\text { Revenue, Expenditure, Balance and Composition of } \\
\text { Financing }{ }^{3} \text { - Central Government }\end{array}$ & $6 / 05$ & $8 / 05$ & M & M & M & & \\
\hline $\begin{array}{l}\text { Stocks of Central Government and Central } \\
\text { Government-Guaranteed Debt }\end{array}$ & 2004 & $1 / 05$ & A & A & A & & \\
\hline External Current Account Balance & $6 / 05$ & $8 / 05$ & A & A & A & LO, LO, LNO, LO & LO, LO, LO, LO, LNO \\
\hline Exports and Imports of Goods and Services & $7 / 04$ & $8 / 05$ & A & A & A & & \\
\hline GDP/GNP & 2004 & $3 / 04$ & A & A & A & LNO, LO, LNO, LO & LO, LNO, LO, LO, LNO \\
\hline Gross External Debt & 2004 & $1 / 28 / 05$ & A & A & A & & \\
\hline
\end{tabular}

${ }^{1}$ Includes reserve assets pledged or otherwise encumbered as well as net derivative positions.

${ }^{2}$ Both market-based and officially determined, including discount rates, money market rates, rates on treasury bills, notes and bonds.

${ }^{3}$ Foreign, domestic bank, and domestic nonbank financing.

${ }^{4}$ The general government consists of the central government (budgetary funds, extra budgetary funds, and social security funds) and state and local governments.

${ }^{5}$ Including currency and maturity composition.

${ }^{6}$ Daily (D), Weekly (W), Monthly (M), Quarterly (Q), Annually (A), Irregular (I); or Not Available (NA).

${ }^{7}$ Reflects the assessment provided in the data ROSC or the Substantive Update (published on July 8, 2005, and based on the findings of the mission that took place during July 8-24, 2003)

for the dataset corresponding to the variable in each row. The assessment indicates whether international standards concerning concepts and definitions, scope, classification/sectorization,

and basis for recording are fully observed (O), largely observed (LO), largely not observed (LNO), or not observed (NO).

${ }^{8}$ Same as Footnote 7, except referring to international standards concerning source data, statistical techniques, assessment and validation of source data, assessment and validation of intermediate data and statistical outputs, and revision studies. 
Tegucigalpa, Honduras

November 21, 2005

Mr. Rodrigo de Rato

Managing Director

International Monetary Fund

Washington, D.C. 20431

U.S.A.

Dear Mr. de Rato:

1. The attached Supplementary Memorandum of Economic Policies (SMEP) updates economic developments and policy implementation under the PRGF arrangement approved in February 2004, and sets out specific objectives and targets through 2006, as well as performance criteria (PC) for end-June 2006. Based on the strong performance under the program and policies adopted, we request completion of the third review under the PRGF arrangement; the modification of the end-December 2005 PC on the deficit of the central government; the incorporation of an adjustor to the deficit targets for end-December 2005 for up to the equivalent of 0.25 percent of GDP for additional poverty-reducing spending financed with concessional external resources; a waiver of the PC on unfinanced appropriations; and the establishment of corresponding PCs for end-June 2006.

2. We request a waiver on the nonobservance of the continuous $\mathrm{PC}$ on unfinanced appropriations, which was breached when congress imposed the cost of a 10-day fuel price freeze on the budget. This request is based on the corrective measures that we have adopted (offsetting expenditure cuts amounting to less than 0.1 percent of GDP), as well as to the minor and temporary nature of the breach.

3. Economic performance through June 2005 has been consistent with our program. Macroeconomic policies have been in line with the PRGF arrangement, and progress has been made on the structural agenda.

4. Honduras reached the completion point under the enhanced Heavily Indebted Poor Countries (HIPC) Initiative in April 2005. We remain committed to continue good faith negotiations with all non-Paris Club official and private creditors to seek debt relief comparable to that granted by Paris Club creditors under the enhanced HIPC Initiative.

5. We are confident that the policies and measures set forth in the SMEP are adequate to achieve the program's objectives under the PRGF arrangement. However, we stand ready to take further measures that may be needed for the successful implementation of the program. To this end, we will continue consulting with the Fund on relevant economic and financial policies, and provide the Fund with the necessary data on a timely basis for monitoring purposes. Consistent with our intention to keep the public informed about our policies and 
objectives, the government will publish the SMEP and will report on the progress of the program periodically.

6. We propose conducting the fourth review under the PRGF arrangement in April 2006, based on the observance of end-December 2005 quantitative PCs and the structural PCs proposed in the attached SMEP, and the fifth review in September 2006, based on observance of end-June 2006 quantitative PCs.

7. We assure you that the Government of Honduras remains committed to the implementation of the program.

Sincerely yours,

/s/

María Elena Mondragón de Villar

President

Central Bank of Honduras
$/ \mathrm{s} /$

William Chong Wong Minister of Finance 


\section{SuPPlementary MEMORANDUM OF ECONOMiC POLICIES OF THE GOVERNMENT OF HONDURAS}

1. This memorandum of economic policies supplements the original Memorandum of Economic Policies and its subsequent modifications, and sets out the policies and objectives for 2006.

\section{Macroeconomic framework}

Honduras: Selected Economic Indicators

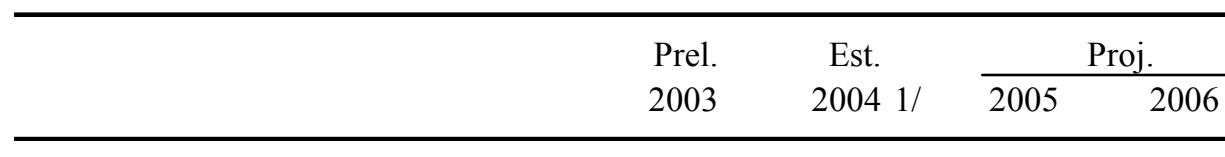

(Percent of GDP, unless otherwise stated)

\begin{tabular}{lrrrr} 
Real GDP (percent) & 3.5 & 4.6 & 4.2 & 4.3 \\
Inflation (eop, in percent) & 6.8 & 9.2 & $8.0-9.0$ & $6.0-7.0$ \\
$\quad$ & & & & \\
$\quad$ Anti-poverty spending & 7.5 & 8.4 & 8.7 & 9.4 \\
Capital expenditure 2/ & 27.4 & 6.5 & 7.7 & 7.6 \\
$\quad$ Total revenue 2/ & & & & \\
$\quad$ Of which & 1.1 & 1.0 & 1.7 & 1.7 \\
$\quad$ Grants & 10.5 & 10.1 & 9.8 & 9.6 \\
$\quad$ Central government wage bill & -5.1 & -3.0 & -2.5 & -1.7 \\
$\quad$ Combined public sector balance & & & & \\
$\quad$ Of which $\quad$ Financed domestically & 3.2 & -1.6 & -0.3 & -0.3 \\
$\quad$ Central government balance & -6.0 & -3.5 & -3.2 & -2.5 \\
$\quad$ & -4.2 & -4.7 & -2.1 & -2.9 \\
$\quad$ External current account balance & & & & \\
\hline
\end{tabular}

1/ For 2004 preliminary estimate.

$2 /$ For the combined public sector.

2. Growth. GDP is projected to grow by 4.2 percent in 2005 , led by the textile, tourism, construction, and telecommunications sectors. Based on the strength of private investment and exports, and on the confidence-boosting effects of CAFTA, we expect economic growth to accelerate to 4.3 percent in 2006 and 4.5 percent in subsequent years.

3. Inflation. Reflecting continued increases in international oil and fuel prices, including the sharp spike following Hurricanes Katrina and Rita, we now expect 2005 inflation (eop) to finish in the 8.0-9.0 percent range, compared with the original 6.9 percent target. The central bank remains committed to adopting measures to avoid second-round effects on prices from the rise in oil prices, and to return inflation to the agreed medium-term 
path. Consistent with this objective, the CPI inflation objective for 2006 is set at a range of 6.0-7.0 percent. $^{1}$

4. External current account. Despite higher oil prices, which are being offset by strong family remittances (projected to grow from 15.7 percent of GDP in 2004 to 20.7 percent of GDP in 2005), and growth of maquila and other exports already observed during the first half of this year, the external current account deficit is now projected to drop to 2.1 percent of GDP in 2005 , compared to 2.5 percent of GDP originally envisaged.

5. Net international reserves (NIR). In line with the improvement in the current account deficit, the central bank has projected an increase of net international reserves of about US\$280 million this year. However, the NIR target for end-2005 will remain unchanged. In 2006, NIR are expected to rise by about US\$180 million.

\section{Fiscal policy}

6. Deficit targets. The 2005 deficit target for the combined public sector will remain at 2.5 percent of GDP while the central government deficit target will be revised slightly, to 3.2 percent of GDP. Poverty-reduction spending will rise to 8.7 percent of GDP, in accordance with the original commitment. The indicative ceilings on the deficits of the central government (CG) and combined public sector (CPS) for 2006 remain unchanged.

7. Impact of oil prices. To cushion the impact of high oil prices on the poor, the government has already increased and extended the subsidy given to low-income households (including consumers of between $100 \mathrm{kwh}$ and $300 \mathrm{kwh}$ of electricity per month) at an additional fiscal cost of 0.1 percent of GDP. The government will offset this expenditure with cuts in other expenditures, including public investment. We will continue consulting with Fund staff on policy responses to any further increase in oil prices, including on measures to mitigate the impact on the poor.

8. Fuel pricing. Last month we reintroduced a flexible fuel price adjustment mechanism for all fuel products except for LPG (which is used for mostly domestic cooking). Therefore, other fuel prices are not guided by the price ceilings and are now set by an automatic formula that adjusts domestic prices with a five-day lag, based on average international prices and fixed margins for importers and distributors and taxes - the same formula that applied before Hurricane Katrina disrupted fuel markets. We intend to continue to adjust these prices automatically in line with this formula, with the remaining subsidy on LPG contained below agreed amounts in 2005 and accommodated within the agreed fiscal program in 2006. In due course, after the commission issues its recommendations, the government is expected to return to the fuel pricing issue.

\footnotetext{
${ }^{1}$ These projections do not consider potential effects derived from further increases in international oil prices.
} 
9. Fiscal implications of fuel pricing. The budget will absorb the cost of the fuel price freeze while maintaining the fiscal discipline that is at the core of Honduras' program. The fiscal cost of the fuel freeze will be capped at about 0.2 percent of GDP (L 300 million), and could be accommodated within the overall fiscal framework for 2005. Although the central government deficit would be increased somewhat (by 0.2 percent of GDP or L 370 million), the overall deficit would remain unchanged due to a lower-than-projected quasi-fiscal deficit (by 0.1 percent of GDP on account of higher-than-projected international interest rates) and delays in public investment (amounting to 0.1 percent of GDP, on projects of the public telephone and electricity companies). Spending on social programs (PRSP anti-poverty spending) and public investment will not be reduced, except for the projects noted above. In addition, we will allow the price controls on basic foodstuffs imposed along with the fuel price freeze to expire as scheduled at end-December 2005 (performance criterion).

10. Adjustor to fiscal deficit targets. To allow for the faster execution of investment projects, an adjustor will be introduced to the performance criteria on central government and the consolidated public sector deficit targets for poverty-reducing (PRSP) spending in excess of the program target, to be financed by additional concessional loans, for up to 0.25 percent of GDP (L 390 million).

11. Wage policy in 2005. The salaries law passed in December 2003 and the July 2004 wage agreement with teachers will remain in force, as agreed under the program.

12. The 2006 budget. The government submitted a draft 2006 budget to congress in September. The proposed budget is consistent with a combined public sector deficit of 1.7 percent of GDP, while the wage policy will be consistent with the December 2003 salaries law and July 2004 agreement with the teachers. Poverty-reducing spending in 2006 will rise to 9.4 percent of GDP. Passage of a budget for 2006 consistent with the program will be a prior action for the fourth review.

13. Tax revenue. The government will continue to implement the new Tax Code, including by enforcing its recently acquired power to determine taxpayers' income through indirect methods and third-party information. In addition, the Ministry of Finance will continue to implement measures to strengthen tax administration.

- Audit plan. The number of large taxpayer audits will rise to 225 (cumulative) by end-December 2005 (benchmark), from the 168 audits completed through June 2005, with improved cooperation between the tax and customs offices. The audit capacity will be improved through further modernization of computer systems (particularly the databases on large taxpayers) and training of staff.

- $\quad$ Large taxpayer stop-filers. The rate of stop-filers will be reduced from 3.3 percent of large taxpayers in June 2005 to 2.0 percent in December 2005. To accomplish this, the DEI will continue to strengthen its computerized cross-checking, supported by an increase in the number of electronic filers, and will effectively enforce the sanctions introduced in the new Tax Code. 
14. Hondutel. The state-owned company, Hondutel, which has a monopoly over long distance telephone service, will face competition starting in January 2006. With the assistance of investment advisors, we have quantified the net fiscal impact of the reform (amounting to a revenue reduction of 0.5 percent of GDP in 2006). As a prior action, the government has identified the measures to close the fiscal gap as identified in the Supplementary Technical Memorandum of Understanding. Adoption of these measures will be a prior action for the fourth review.

15. Fiscal effects of CAFTA. The revenue loss from CAFTA due to lower trade taxes is estimated at 0.25 percent of GDP in 2006 . We have addressed the revenue shortfall in the 2006 budget submission to congress through lower expenditures.

16. Pension reform. We are planning a comprehensive pension reform which would introduce a two-pillar system, including a basic pension for all workers (pay-as-you-go) and a defined-contribution scheme with personal accounts. We will consult with the Fund on the financial implications of such a reform before it is approved. The government will ensure that such a reform is consistent with the medium-term fiscal framework.

\section{Monetary and exchange rate policy and management}

17. Reform of monetary operations. In May, the central bank introduced a number of changes to monetary operations, including the establishment of an overnight interest rate corridor; the issuance of 7-day central bank securities; and bi-weekly auctions of 90-360 day securities to manage structural liquidity. These steps would facilitate a future transition toward greater exchange rate flexibility. In addition, the central bank will allow for greater market determination of interest rates for central bank securities. The central bank will separate the front-, middle- and back-office of the monetary operations department (benchmark), which would allow for the subsequent creation of a money desk.

18. Monetary policy strategy. The central bank will use open market operations as the main instrument to contain inflation, including by increasing the interest rate, if necessary, to meet the program's objectives.

19. Obligatory investments. Obligatory investments (OI), equivalent to 2 percent of deposits held by financial institutions, were reduced by 1 percentage point in October for lempira deposits and will be eliminated by end-November 2005. The monetary impact will be offset by compensating open market operations.

20. Exchange rate policy. The annual rate of crawl of the exchange rate was reduced in May to about 1 percent (from 3 percent), and will average about 2 percent in 2005. In 2006, the annual rate of crawl will average 2 percent. 


\section{Financial sector reform}

21. Prudential regulations on banks' foreign currency operations. The existing framework for foreign currency operations will be improved through the issuance of a norm (benchmark) with the following provisions:

- $\quad$ The risk weighted capital requirement for loans to non-foreign currency earners will be 150 percent for non-mortgage loans and 100 percent for mortgage loans.

- $\quad$ The net open foreign exchange position will be limited to 50 percent of capital.

- $\quad$ A bank's foreign currency lending to non-foreign currency earners will be limited to one times capital, until the National Commission of Banks and Insurance (CNBS) approves the bank's lending policies and risk management.

- $\quad$ Foreign currency earners will be defined as in the Supplementary Technical Memorandum of Understanding.

- Upon approval of this norm, the current limits on banks' external indebtedness will be eliminated.

22. Obligatory investment and liquidity requirements on FC liabilities. Once the above framework is in place, the central bank will eliminate the 2 percent OI requirement on foreign currency deposits and reduce the liquidity requirement on foreign currency deposits from 38 to 30 percent. The CNBS will impose an 8 percent liquidity requirement on all external loans of banks. The latter constitutes a first step in a gradual process to level the playing field with banks from the region facing lower requirements in a way consistent with macroeconomic stability.

23. Other measures in 2005. Other financial sector reforms will include:

- Bank soundness. The enhanced legal and prudential framework approved last year, including capital adequacy requirements, loan classification rules and provisioning requirements will be fully enforced. The CNBS will ensure that banks meet the threeyear program that would raise their loan provisions closer to international standards by end-2006.

- $\quad$ Bank resolution. The CNBS will complete the procedures to enable the implementation of the new bank resolution mechanism (including the issuance of norms) and the liquidation of financial assets of failed institutions.

- $\quad$ Bankruptcy. The government will submit to congress by December 2005 a law to improve the following legal frameworks for corporate reorganization and bankruptcy proceedings, creditor rights, and corporate governance of nonfinancial business corporations. 
- Anti-terrorism. The government will submit to congress by December 2005 draft legislation to penalize the financing of terrorism in accordance with international best practices.

\section{Other issues}

24. Transparency. We are committed to a policy of transparency. To this end, we have consented to the publication of the staff report for the third review of the PRGF arrangement. The data ROSC has already been published. In addition, we joined the GDDS in October 2005, and the central bank will continue providing the Fund with full financial statements (including auditor's notes) and will continue to publish them by end-June every year. The CNBS will continue to require that commercial banks publish quarterly financial statements.

\section{Program modalities}

25. Conditionality. Performance criteria and financial benchmarks for 2005 and 2006 are shown in Table 1 and structural targets are included in Table 2. 
Table 1. Honduras: Financial Benchmarks and Performance Criteria for 2005-06 under the PRGF Arrangement 1/

\begin{tabular}{|c|c|c|c|c|c|c|c|c|}
\hline & \multicolumn{4}{|c|}{ Prog. 2005} & \multicolumn{4}{|c|}{ Proposed 2006} \\
\hline & Mar. & Jun. & Sep. & Dec. & Mar. & Jun. & Sep. & Dec. \\
\hline \multicolumn{9}{|l|}{ Performance criteria 2/ } \\
\hline \multicolumn{9}{|c|}{ (End-of-period stocks in millions of lempiras, unless otherwise specified) } \\
\hline Ceiling on net domestic assets of the central bank 3/ & $-22,590$ & $-23,379$ & $-24,632$ & $-24,579$ & $-26,508$ & $-27,566$ & $-28,624$ & $-27,724$ \\
\hline Actual & $-23,554$ & $-24,908$ & $-25,833$ & $\ldots$ & $\ldots$ & $\ldots$ & $\ldots$ & $\ldots$ \\
\hline $\begin{array}{l}\text { Floor on net international reserves of the central bank } \\
\text { (in millions of U.S. dollars) 3/ }\end{array}$ & 1,653 & 1,703 & 1,713 & 1,833 & 1,930 & 1,980 & 1,980 & 2,082 \\
\hline Actual & 1,724 & 1,794 & 1,822 & $\ldots$ & $\ldots$ & $\ldots$ & $\ldots$ & $\ldots$ \\
\hline \multicolumn{9}{|c|}{ (Cumulative amounts in millions of lempiras, for each year) } \\
\hline Ceiling on the wage bill of the central government & 3,299 & 7,455 & 10,841 & 15,149 & 3,599 & 8,481 & 11,846 & 16,663 \\
\hline Actual & 2,919 & 7,104 & & & & & & \\
\hline $\begin{array}{l}\text { Ceiling on the overall deficit of the central government } 4 \text { / } \\
\text { Actual }\end{array}$ & $\begin{array}{r}520 \\
1,119\end{array}$ & $\begin{array}{r}1,667 \\
644\end{array}$ & 1,892 & 4,932 & 1,214 & 1,614 & 1,863 & 4,383 \\
\hline Ceiling on the overall deficit of the combined public sector & 680 & 1,752 & 1,592 & 3,859 & 2,381 & 1,860 & 490 & 3,007 \\
\hline Actual & 306 & -557 & & & & & & \\
\hline Ceiling on net domestic financing of the combined public sector $3 /$ & 223 & 149 & $-1,349$ & -532 & 1,894 & 721 & $-1,572$ & -564 \\
\hline Actual & -69 & $-2,254$ & $\ldots$ & $\ldots$ & $\ldots$ & $\ldots$ & $\ldots$ & $\ldots$ \\
\hline $\begin{array}{l}\text { Ceiling on contracting or guaranteeing of nonconcessional external } \\
\text { debt of the combined public sector (in millions of U.S. dollars) } 5 /\end{array}$ & & & & 0 & 0 & 0 & 0 & 0 \\
\hline Actual & 0 & 0 & . & . & ... & 0 & 0 & 0 \\
\hline Ceiling on accumulation of arrears on external debt-service payment & & & & & & & & \\
\hline of the public sector (in millions of U.S. dollars) 6/ & 0 & 0 & 0 & 0 & 0 & 0 & 0 & 0 \\
\hline Actual & 0 & 0 & $\ldots$ & ... & $\ldots$ & $\ldots$ & $\ldots$ & ... \\
\hline \multicolumn{9}{|l|}{ Financial benchmarks } \\
\hline Floor on the operating surplus of the public enterprises & 1,016 & 2,032 & 3,048 & 4,064 & 940 & 1,881 & 2,821 & 3,761 \\
\hline Actual & 1,157 & 1,950 & & & & & & \\
\hline Floor on anti-poverty spending & 3,317 & 6,634 & 9,950 & 13,267 & 4,058 & 8,116 & 12,175 & 16,233 \\
\hline Actual & 3,070 & 6,762 & $\ldots$ & $\ldots$ & $\ldots$ & $\ldots$ & $\ldots$ & $\ldots$ \\
\hline
\end{tabular}

Sources: Central Bank of Honduras; Ministry of Finance; and Fund staff estimates.

$1 /$ As defined in the technical memorandum of understanding.

2/ Performance criteria are for end-June, end-December 2005 and end-June 2006; other targets are indicative.

3/ The NIR floor will be adjusted downward and the NDA ceiling would be adjusted upward for shortfalls in foreign exchange inflows up to an amount of US $\$ 100$ million. The 2005 program will include a capped adjuster of 0.75 percent of GDP on the ceiling on domestic financing for temporary (within-year) shortfalls in foreign financing.

4/ For 2005 the figure shown reflects the proposed revision

5/ Includes short-term (up to and including one year) maturities monitored on a semi-annual basis, and long-term (over one year) maturities, monitored on a continuous basis.

6/ Monitored on a continuous basis. 
Table 2. Honduras: Structural Targets for 2004-06 under the PRGF Arrangement

\begin{tabular}{|c|c|c|c|c|}
\hline & Conditionality $1 /$ & Target Date & Status & \\
\hline \multicolumn{5}{|l|}{ Financial and monetary sector reform } \\
\hline 1. Adoption of a new financial institutions law. & $\mathrm{PA}$ & September 2004 & Completed in September 2004 & \\
\hline $\begin{array}{l}\text { 2. Adoption of a new Financial Institutions Law and amendment of the CNBS Law, the } \\
\text { Deposit Insurance Law, and the Central Bank of Honduras Law to strengthen financial } \\
\text { regulation, supervision, and the financial safety net. }\end{array}$ & PC & End-June 2004 & All laws approved in September 2004 & \\
\hline $\begin{array}{l}\text { 3. Finalizing a timetable to comply with new regulations on capital adequacy, loan } \\
\text { classification, and provisioning (including on investment in FONAPROVI bonds). }\end{array}$ & PC & End-June 2004 & Completed in June 2004 & \\
\hline $\begin{array}{l}\text { 4. Finalizing a timetable to make the use of indirect instruments of monetary management } \\
\text { more effective and improve interest rate signaling. }\end{array}$ & $\mathrm{PC}$ & End-September 2004 & $\begin{array}{l}\text { Completed in September } 2004 \text { with the } \\
\text { assistance of technical advisory missions } \\
\text { from MFD }\end{array}$ & \\
\hline $\begin{array}{l}\text { 5. Launch the mechanism to make the use of indirect monetary instruments more effective } \\
\text { and improve interest rate signaling. }\end{array}$ & $\mathrm{PC}$ & End-December 2004 & Completed in December 2004 & \\
\hline 6. Amendment of the Penal Code to make financial crimes punishable. & SB & End-September 2004 & Completed in December 2004 & \\
\hline 7. Finalization of an action plan to accelerate asset recovery from failing banks. & SB & End-September 2004 & Completed in September 2004 & \\
\hline $\begin{array}{l}\text { 8. Publication of full central bank financial statements, including the external auditor's } \\
\text { opinion and the explanatory notes. }\end{array}$ & SB & End-June 2005 & Completed in April 2005 & 1 \\
\hline 9. Enforcement of requirement that banks publish quarterly financial statements. & SB & Continuous & Met through October 2005 & ư \\
\hline $\begin{array}{l}\text { 10. Enforcement of new prudential regulations on capital adequacy ratio, loan } \\
\text { classification, and provisioning requirement in line with the new financial sector law. }\end{array}$ & $\mathrm{PC}$ & Continuous & Met through October 2005 & \\
\hline 11. Operational implementation by the central bank of the interest rate corridor. & SB & End-June 2005 & Done in May 2005 & \\
\hline $\begin{array}{l}\text { 12. CNBS will expand data collection of unhedged dollar loans and issue supervisory and } \\
\text { inspection guidelines on these loans. }\end{array}$ & SB & End-June 2005 & Done in July 2005 & \\
\hline 13. Separate front-, middle- and back-office of central bank's Monetary Department. & SB & End-December 2005 & & \\
\hline $\begin{array}{l}\text { 14. CNBS will issue prudential norms to enhance the regulations for foreign currency } \\
\text { operations. }\end{array}$ & SB & End-December 2005 & & \\
\hline \multicolumn{5}{|l|}{ Fiscal sector reform } \\
\hline $\begin{array}{l}\text { 15. Issue of regulations to integrate supplementary benefits into the overall salary } \\
\text { from } 2007 \text { on as envisaged in the salaries law, in accordance with the conclusions of the } \\
\text { special wage commission. }\end{array}$ & $\mathrm{PC}$ & End-December 2004 & Not done, postponed. & $\stackrel{P}{9}$ \\
\hline $\begin{array}{l}\text { 16. Passage of a } 2005 \text { budget consistent with the macroeconomic targets and other } \\
\text { objectives of the program supported by the PRGF arrangement, including all tax } \\
\text { and tariff measures needed to meet the } 2005 \text { deficit target. }\end{array}$ & $\mathrm{PC}$ & End-December 2004 & Done. Budget approved in December 2004 & 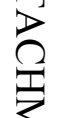 \\
\hline $\begin{array}{l}\text { 17. Finalization of an action plan for public administration reform, consistent with } \\
\text { World Bank recommendations. }\end{array}$ & SB & End-April 2004 & Completed in May 2004 & I \\
\hline 18. Amendment of the Tax Code in line with understandings under the program. & SB & End-September 2004 & Completed in December 2004 & 尸 \\
\hline
\end{tabular}

CInternational Monetary Fund. Not for Redistribution 
Table 2. Honduras: Structural Targets for 2004-06 under the PRGF Arrangement

\begin{tabular}{|c|c|c|c|}
\hline & Conditionality $1 /$ & Target Date & Status \\
\hline 19. Full automation of poverty-reduction expenditure tracking. & SB & End-December 2004 & Completed in December 2004 \\
\hline 20. Establishment of two chambers of Tax Courts. & SB & End-December 2004 & $\begin{array}{l}\text { The Supreme Court established Tax Court } \\
\text { chambers in December } 2004\end{array}$ \\
\hline 21. Finalize the necessary technical work for the integrated permanent salary system. & $\mathrm{PA}$ & March 14, 2005 & Done \\
\hline 22. Permanent suppression of intra-year unfinanced appropriations. & $\mathrm{PC}$ & Continuous & $\begin{array}{l}\text { Missed in September } 2005 \text { when congress decided } \\
\text { that the cost of the fuel freeze would be financed by } \\
\text { the budget. Waiver requested. }\end{array}$ \\
\hline $\begin{array}{l}\text { 23. The number of large taxpayers' audits will rise to } 100 \text {, and the rate of stopfilers is targeted to } \\
\text { fall to } 3.7 \text { percent. }\end{array}$ & SB & End-June 2005 & $\begin{array}{l}\text { Done. Targets were exceeded in June, with large } \\
\text { taxpayers' audits reaching } 168 \text {, and the rate of } \\
\text { stopfilers dropping to } 3.3 \text { percent }\end{array}$ \\
\hline $\begin{array}{l}\text { 24. Submission of a } 2006 \text { budget consistent with the macroeconomic targets and other } \\
\text { objectives of the program supported by the PRGF arrangement, including all tax } \\
\text { and tariff measures needed to meet the } 2006 \text { deficit target. }\end{array}$ & $\mathrm{PA}$ & Third Review & Done. Budget submitted in September 2005 \\
\hline $\begin{array}{l}\text { 25. The number of large taxpayers' audits will rise to } 225 \text {, and the rate of stopfilers is } \\
\text { telecommunications market }\end{array}$ & SB & End-December 2005 & \\
\hline $\begin{array}{l}\text { 26. Identify measures to close the fiscal gap derived from the opening of the } \\
\text { telecommunications market }\end{array}$ & $\mathrm{PA}$ & Third Review & \\
\hline 27. Elimination of price controls over basic foodstuffs $2 /$ & $\mathrm{PC}$ & End-December 2005 & \\
\hline 28. Passage of a 2006 budget consistent with the program. 3/ & PA & Fourth review & \\
\hline $\begin{array}{l}\text { 29. Adopt measures to close the fiscal gap derived from the opening of the } \\
\text { telecommunications market } 3 \text { / }\end{array}$ & PA & Fourth review & \\
\hline
\end{tabular}

1/ $\mathrm{PA}=$ prior action; $\mathrm{PC}=$ performance criteria; $\mathrm{SB}=$ structural benchmark .

2/ As issued on September 8 by Congressional Decree 278-2005.

3 / PA for the fourth review. 


\section{Supplementary Technical Memorandum of Understanding}

1. This Supplementary Technical Memorandum of Understanding (TMU) complements the original TMU and its subsequent modifications.

2. The authorities identified the following measures to close the fiscal gap in 2006 arising from competition in the long distance telephone market (expected proceeds included in parentheses):

- $\quad$ raising the rates on domestic service to regional levels (0.2 percent of GDP);

- $\quad$ introducing a termination charge for international calls from other carriers (0.1 percent of GDP);

- improving collections for incoming international traffic (that goes unbilled) through the use of brokers ( 0.1 percent of GDP); and

- $\quad$ other measures including rebalancing local tariffs, slowing down growth in the wage bill, and increased fees from mobile networks ( 0.1 percent of GDP).

3. For the purpose of the enhanced prudential framework for banks' foreign exchange operations, foreign exchange earners will be defined according to the following parameters:

- $\quad$ Firms located in Honduras that export good and services;

- $\quad$ Firms that hold an irrevocable bank guarantee from an international financial institution qualified as first-rate by the central bank;

- Subsidiaries of foreign firms, corporations or consortia when the parent company holds an investment-grade rating and guarantees the liabilities in foreign currency of the subsidiary;

- $\quad$ Firms that provide inputs, raw materials or other goods and services to exporting firms when the former have contracts with an exporting company and payment is received in foreign currency, to the extent that the foreign exchange cash flow adequately covers debt service. 


\section{Statement by the IMF Staff Representative December 16, 2005}

The following information, which does not alter the thrust of the staff appraisal, has become available since the staff report was issued.

1. Elections. Mr. Manuel Zelaya (of the opposition Liberal party) won the presidential race with about 50 percent of the vote and will take office on January 27. It is likely that no party will enjoy a majority in congress. Staff have had early contacts with the president-elect, who has expressed his support for the PRGF arrangement and indicated he would continue to successfully implement the program until its expiration in February 2007.

\section{Recent macroeconomic indicators point to a strong recovery with stability.}

- In the period January-September 2005, the monthly indicator of economic activity grew by 4.6 percent over same period in 2004, suggesting the growth objective of 4.2 percent in 2005 could be surpassed.

- $\quad$ Twelve-month inflation fell to 7.7 percent in November on account of lower fuel prices, a slower rate of crawl, and the statistical impact of high inflation in November 2004.

- $\quad$ As of end-November, NIR had risen to US\$1.9 billion owing mainly to continued strong growth in family remittances. NIR levels have already exceeded the target for end-2005 by about US\$70 million ( 0.8 percent of GDP).

- All indicative targets for end-September were met, except for the floor on the operating surplus of the public enterprises, which was missed by 0.1 percent of GDP.

3. Gasoline prices have declined by 4 percent on average (as of December 11) since the reintroduction of a flexible price-setting mechanism on October 18, reflecting trends in international oil prices. Prices on liquid propane gas remain frozen at pre-Katrina levels.

4. Conditionality. The program's continuous performance crieria on enforcement of banks' publication of quarterly statements and new prudential regulations were met through end-November 2005.

5. Bilateral debt agreements. Since the issuance of the staff report, bilateral debt agreements in the context of Paris Club relief were signed with Japan and Germany.

6. Fuel pricing. The Commission of Notables issued its recommendations, which focus primarily on the direct importation of fuels by the government. The president-elect has formed a task force to review the recommendations and no immediate action is expected. 
Press Release No. 05/280

FOR IMMEDIATE RELEASE

December 16, 2005
International Monetary Fund

Washington, D.C. 20431 USA

\section{IMF Executive Board Completes Third Program and Financing Assurances Reviews under Honduras' PRGF Arrangement}

The Executive Board of the International Monetary Fund (IMF) has completed the third review of Honduras' performance and the financing assurances review under an SDR 71.2 million (about US\$102.7 million) Poverty Reduction and Growth Facility (PRGF) arrangement approved on February 27, 2004 (see Press Release No. 04/29). ${ }^{1}$

The completion of this review allows Honduras to draw a further SDR 10.17 million (about US\$14.7 million), bringing the total amount released under the arrangement to SDR 40.68 million (about US\$58.7 million). In completing the review, the Board approved the request for waiver and modification of performance criteria. The Board waived the nonobservance of the performance criterion on unfinanced budget appropriations.

Following the discussion of the Executive Board, Mr. Agustín Carstens, Deputy Managing Director and Acting Chair, made the following statement:

“The Honduran authorities' implementation of sound macroeconomic policies and progress with structural reforms under their Fund-supported program have continued to produce positive results. In 2005 economic growth has remained robust, while inflation will fall despite higher fuel prices. The external sector has strengthened significantly on account of substantial family remittances and higher exports. Prospects are good for continued economic growth and a further decline in inflation in 2006.

"The fiscal position has also strengthened, owing in particular to control over public expenditures - including the wage bill — and better-than-expected tax collections. Resolute implementation of the authorities' medium-term fiscal strategy will be critical to maintain macroeconomic stability and fiscal sustainability. Key fiscal challenges ahead will be to keep control over the wage bill in a sustainable manner, including by integrating teachers' benefits and salaries, to implement a prudent budget for 2006 and other identified measures to offset the

\footnotetext{
${ }^{1}$ The staff report for the PRGF review with Honduras will be made available at a later stage if the authorities consent.
}

Washington, D.C. 20431 • Telephone 202-623-7100 • Fax 202-623-6772 • www.imf.org 
fiscal impact of telecom reform and the implementation of the Central American Free Trade Agreement, and to address the deteriorating financial condition of the public electricity firm.

"Structural reforms continue to advance, including the strengthening of the central bank's ability to conduct monetary policy and reduce inflation. Prudential regulations are being tightened to enhance financial sector soundness, particularly in relation to commercial banks' foreign currency operations. The authorities are also returning to a flexible pricing mechanism for petroleum products to limit the cost of fuel subsidies and improve economic efficiency. To cushion the impact of high oil prices on vulnerable groups, the authorities have introduced targeted subsidies and an expanded social safety net.

"Honduras is now entering a political transition, with a new government taking office in January 2006. While the new administration will establish its own policy priorities, its commitment to protect the core elements of the economic program will position Honduras to make significant gains in entrenching growth and fighting poverty in the years to come," Mr. Carstens said. 


\section{Statement by Moises Schwartz, Executive Director for Honduras and Nina Conrado, Senior Advisor to Executive Director December 16, 2005}

On behalf of the authorities of Honduras, we would like to thank management and staff for their policy advice and their appreciable work with the country, especially during the last years. This review is specially meaningful for the Honduran authorities, since it is the first review after achieving the HIPC completion point and the last review under the present administration of President Maduro. This review is also important because it provides the country with a unique opportunity to continue implementing sound macroeconomic policies and advancing in the structural reform agenda in an orderly manner, as it is the first time for Honduras that a program has been maintained on track during an electoral period. The achievements carried out by the commitment and ownership of the program of this administration will allow the country to advance in the objectives of sustained growth and poverty reduction, efforts that would further be supported with the recently approved Multilateral Debt Relief Initiative (MDRI). In this context, my authorities also wish to convey their appreciation to Executive Directors and the international community for their decisive commitment to help the poor and their continuous support to the country.

Economic conditions in Honduras have clearly improved, despite the mixed external and domestic environment. During the past years, global growth resulted in a strong demand for Honduran's exports, which together with favorable international prices have produced a stronger export performance. At the same time, growth of remittances and the positive performance of maquila have helped mitigate the impact of high oil prices in the current account. This, coupled with a responsible fiscal policy supported by external financing, has permitted a strengthening of international reserves.

Domestically, the challenges have included a great effort to consolidate public finances, especially in a context of high demands for wage increases, subsidies to deal with the adverse impact of high fuel prices, emergency costs related to floods due to hurricanes and tropical storms, and the uncertainties related to the electoral cycle. However, growth has been resilient, reflecting stronger confidence of the private sector. The monthly indicator of economic activity for September reflects a 4.6 percent growth rate, consistent with the projected real GDP growth of 4.2 percent for the year.

Honduras's policy to deal with the impact of high fuel prices has been responsible, protecting the more vulnerable and preserving the fiscal stance. However, in September, the spike in oil prices derived from Hurricanes Katrina and Rita took place in the mist of a complicated time due to the tense political environment of the elections and the threats of widespread social unrest. The initial response of the government was to maintain a flexible mechanism of fuel price determination and enhance programs to protect the most vulnerable. Nevertheless, political tensions resulted in a congressional decision to freeze temporarily fuel prices and extend subsidies, with the corresponding budgetary subsidy, and the establishment of price controls of basic food products. At the same time, in an effort to isolate the economic 
discussion of the fuel problem from the political debate, a Commission of Notables was appointed to revise and make recommendations on the domestic fuel price mechanism.

Despite the budgetary impact of high fuel prices, the adequate framework of fiscal policy permitted an effective response to maintain fiscal discipline and comply with the objectives of the PRGF. In September, the government cut off 25 percent of expenditures in goods and services, while respecting the priorities incorporated in the PRSP and protecting the poor as planned. Last month, with the return of international fuel prices to pre-Katrina levels, a flexible mechanism for fuel price determination was reintroduced, and the elimination of price controls is expected to take place by end December, as scheduled (Structural PC).

All performance criteria for end-June were met with margins, as well as end-September indicative targets. In September, the continuous PC on unfinanced appropriations was not observed as a result of the temporary fuel price freeze approved by congress. The authorities request a waiver on this $\mathrm{PC}$, based on the strong implementation of the program, on the temporality of the breach, as well as on the prompt compensating measures. In order to advance more rapidly with poverty reduction, an adjustor for the end-December 2005 deficit target is being requested (for up to 0.25 percent of GDP), for expenditures to be financed with concessional external resources.

\section{Fiscal policy}

Fiscal consolidation has been at the core of the economic program. The authorities' strategy has included three components: (i) improving revenue collection (ii) control and prioritization of expenditures, (iv) improving financing.

Regarding tax policy, great efforts have been made to widen the tax base through reforms to reduce exemptions and through the modernization of tax administration, including the implementation of the new Tax Code. In 2005, to further advance in this policy, audits plans have been increased and stop-filers have been reduced. A benchmark for both of these measures has been established for the end of the year and full compliance is expected.

A centerpiece of the fiscal strategy has been to establish a sustainable wage policy. This has been a major challenge due to the existence of special regimes, the establishment of agreements under previous administrations and the pressures of interest groups in sensitive sectors. Nevertheless, in 2005, as the staff points out, there has been a strict control over the wage bill. This policy has led to an increase in poverty spending and public investment. The implementations of the poverty reduction strategy has also included a participatory approach in which definitions of poverty-reducing spending have been improved, leading to a prioritization of key social programs.

Part of the government's strategy to consolidate the fiscal balance and to obtain resources to finance poverty reduction projects was to canalize concessional external financing. Earlier this year, the domestic broad base support of the economic and reform program permitted Honduras to reach HIPC completion point, changing significantly the country's sustainability. Once again, the authorities would like to thank the international community 
for this important support, taking this opportunity to call on countries that are not fully participating in the debt reduction initiative to join this effort. The authorities hope that the MDRI will soon be made operational and that Honduras can have prompt access.

As a prior action for this review the government submitted to congress a 2006 budget proposal consistent with the program, targeting a central government deficit of 2.5 percent of GDP, and poverty spending of 9.4 percent of GDP.

\section{Monetary and exchange rate policy, and financial sector reforms}

A prudent monetary policy with an effective coordination with fiscal and financial policies has been a fundamental element in maintaining stability, strengthening international reserves and stabilizing inflation. A key priority of the monetary program has been to sterilize foreign exchange inflows in order to manage liquidity. In this framework, great efforts have been made to modernize monetary policy, which continues to rely on open market operations. In 2005, an overnight central bank interest rate corridor was established (benchmark), and the Central Bank eliminated the temporary remunerated reserve requirement of 2 percent of deposits established in 2004.

The authorities are assessing the convenience of gradually moving towards a more flexible exchange rate system in the medium term, with the appropriate framework. After strengthening the legal framework of financial institutions in 2004, in 2005 prudential norms to regulate foreign currency operations of banks and to control the risk of dollar lending have been put in place. Included in the overall reform agenda of the monetary and financial systems, important steps have been taken in the recapitalization of the central bank and the modernization of the payment system.

Monetary targets have been over performed. For June, the target for international reserves and net domestic assets were met with margins. Consistent with the evolution of the real sector, the positive expectations of the private sector and the strengthening of the financial sector there has been a strong growth of credit and deposits. Positive results are also starting to be reflected in the inflation rate. After surging in 2004 due to high oil prices, in 2005 inflation has stabilized and started to show signs to come down. The annual inflation rate as of November was 7.7 percent, in line with the revised projection of 8-9 percent for the year.

\section{Structural agenda, governance and transparency}

The government's structural reform agenda included the consolidation of the trade liberalization process. A trade agreement was subscribed with Chile, and Honduras was the second country to ratify the Central American Free Trade Agreement (CAFTA-DR). To complement this strategy, important efforts have been made to improve infrastructure, especially in Puerto Cortés, Honduras's main port, and in the modernization of customs procedures.

The government is committed to its anticorruption strategy, and to strengthening the anti laundering framework and criminalization of financing of terrorism. In order to strengthen 
accountability, important reforms have been made in the legislative, judicial and executive branches. The electoral process for the national assembly was reformed, the immunity for public officials was eliminated, and the selection process for Supreme Court Magistrates was changed. The performance of Honduras in a wide set of indicators, including governance and transparency, permitted the country to be the first Latin American country to be selected for the Millennium Challenge Account. This grant will allow the investment of US\$215 millions in infrastructure and agriculture.

As part of the authorities policy to enhance transparency Honduras joined this year the General Data Dissemination System (GDDS) and participated in the ROSC data module. To continue this policy the authorities consent to the publication of the documents related to the third review of the PRGF.

\section{Looking forward}

Despite the government's strong performance, the authorities are aware of the challenges ahead and of the importance of protecting the core elements of the program. Besides the main objective of maintaining and strengthening macroeconomic stability, two major challenges are the continuation of reforms in the energy and telecommunications sectors.

The authorities have succeeded in handing over to the next government a program that is on track, and hope that the broad consensus gathered in the last years will serve as a basis for continuous good policies. This administration had a long term view. During the last four years, despite the negative oil shock, the economy grew and inflation was under control. The fiscal deficit and external debt were reduced, and international reserves and poverty related spending reached historic levels.

The authorities believe that seizing the strategic opportunities of debt relief and CAFTA-DR can mean a significant turn around of Honduras' long term growth and poverty alleviation perspectives. For this to be possible, macroeconomic stability should be maintained, fiscal consolidation should be strengthened, and pro-investment measures and competitiveness enhancing reforms should be fostered. 